\title{
Democracy and Unity in India
}

This book analyzes the ways in which organizations and individuals in India grappled with and contested definitions of democracy and unity in the decades directly preceding and following independent Indian statehood.

The All India Scheduled Castes Federation and the All India Women's Conference are used as case studies to explore Indian Dalit and women activists' attempts to reconceptualize universal citizenship, Indian identity, dissent, and principled democracy during a moment of uncertainty in India's political life. The author argues that, because the Indian nation and the Indian state remained in flux during the 1940s and '50s, marginal political actors, writers, social activists, and others were able to propose novel forms of democratic participation and new ideas about what it would mean to be a unified state that appreciates political responsibility, a respect for difference and a broader perspective of the population. Moreover, this book suggests that this redefinition of Indian politics is more widespread than generally understood and considers how strategies used by both organizations featured have continued to be part of the national story about democracy and dissent in India.

Through an examination of public discourse, caste politics, women's rights advocacy, and popular literature, this book excavates the traces of fundamental uncertainty regarding definitions and expectations of democracy and unity in India. It will be of interest to academics in the fields of modern South Asian history, democracy and nationalism, postcolonialism, gender studies, political organization, and global history.

Emily Rook-Koepsel is the Assistant Director of Academic Affairs at the Asian Studies Center at the University of Pittsburgh in the United States. Her most recent articles consider the link between state violence, public order, and dissent in India. 


\section{Routledge Studies in South Asian History}

13 Citizenship, Community and Democracy in India From Bombay to Maharashtra, c. 1930-1960

Oliver Godsmark

14 India and World War I

A Centennial Assessment

Edited by Roger D. Long and Ian Talbot

15 Foreign Policy of Colonial India

1900-1947

Sneh Mahajan

16 Women and Literary Narratives in Colonial India Her Myriad Gaze on the 'Other'

Sukla Chatterjee

17 Gender, Nationalism, and Genocide in Bangladesh Naristhan/Ladyland

Azra Rashid

18 Evolution, Race and Public Spheres in India

Vernacular Concepts and Sciences (1860-1930)

Luzia Savary

19 Democracy and Unity in India

Understanding the All India Phenomenon, 1940-1960

Emily Rook-Koepsel

20 Memories and Postmemories of the Partition of India Anjali Gera Roy

For more information about this series, please visit: www.routledge.com/asian studies/series/RSSAH. 


\section{Democracy and Unity in India Understanding the All India Phenomenon, 1940-1960}

\section{Emily Rook-Koepsel}

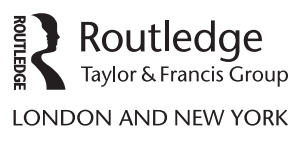


First published 2019

by Routledge

2 Park Square, Milton Park, Abingdon, Oxon OX14 4RN

and by Routledge

52 Vanderbilt Avenue, New York, NY 10017

Routledge is an imprint of the Taylor \& Francis Group, an informa business

(C) 2019 Emily Rook-Koepsel

The right of Emily Rook-Koepsel to be identified as author of this work has been asserted by him/her/them in accordance with sections 77 and 78 of the Copyright, Designs and Patents Act 1988.

All rights reserved. No part of this book may be reprinted or reproduced or utilized in any form or by any electronic, mechanical, or other means, now known or hereafter invented, including photocopying and recording, or in any information storage or retrieval system, without permission in writing from the publishers.

Trademark notice: Product or corporate names may be trademarks or registered trademarks, and are used only for identification and explanation without intent to infringe.

British Library Cataloguing-in-Publication Data A catalogue record for this book is available from the British Library

Library of Congress Cataloging-in-Publication Data

A catalog record has been requested for this book

ISBN: 978-0-367-03088-9 (hbk)

ISBN: 978-0-429-02032-2 (ebk)

Typeset in Times New Roman

by Wearset Ltd, Boldon, Tyne and Wear 
To Abe, Robert, and Simon for their love and support 



\section{Contents}

Acknowledgments $\quad$ ix

1 Introduction: Becoming All India 1

Naming All India 4

Crisis of unity and fundamental similarity 8

Democracy debates 10

The expectation of unity in democracy 12

Belonging, minority, and citizenship in democracy 14

Unity and nation-ness 17

On the meaning of democracy 19

2 Naming caste politics: All India Scheduled Castes

Federation's politics of Indian unity

Naming the constituency 32

Against untouchability 34

Separating unity and singularity 35

Complicated constituencies: Dissent and difference within the All

India Scheduled Castes Federation 39

Conclusion: Advancing negotiated unity 43

3 Democracy, voice, and principle: The political life of the All

India Scheduled Castes Federation

The politics of minority 51

Caste minority politics 53

Building an Indian democracy 55

Voice: On speaking and being heard 60

Principle: Defining ethical minority 63

Conclusion 66 
viii Contents

4 All India women: Citizenship politics of the All India

Women's Conference

Federating Indian women's advocacy and politics 76

Local women's work, national women's work, and All India women's citizenship 80

After independence: Local work, national advocacy, and the All India Women's Conference 86

Conclusion: Locating citizenship 93

5 Conclusion: A national history of "anti-national" dissent

On difference, dissent, and being anti-national 102

Urban Naxals, Indian familyism, and a twenty-first-century crisis of unity 105

Bringing gender and caste together 110

Reading internal minorities in and out of the national story 111

Bibliography

Index 


\section{Acknowledgments}

Very early on in my graduate student career one of my professors, Simona Sawhney, challenged me to think in a principled way. That is, Simona, and most of my subsequent professors at the University of Minnesota, urged me to make my scholarship meaningful, to recognize the politics and privilege of the space that I inhabited, and to build into my scholarship arguments that could act in the world around me. This necessary and revelatory push to understand even historical research as political activism was the starting point for this book, and while I certainly fail in this mission in many ways, where I succeed it is because of the academic, structural, and emotional support of more people than I can list in this small space.

Without the institutional support of the University of Minnesota History Department, the Department of International and Area Studies at the University of Oklahoma, and the Asian Studies Center at the University of Pittsburgh, I never could have completed this project. I would like to thank the staff of the National Archives of India, the Nehru Memorial Museum and Library, the All India PEN association, the Asian and African Collection at the British Library in London, the New York Public Library, and the Asia Collection at the Library of Congress. I am also eternally grateful to the skilled librarians at the Ames Library at the University of Minnesota and the University of Oklahoma librarians for working with me to find what I needed in the library or find a copy for me from all around the globe.

I have also been extremely fortunate to work with several generous funding institutions that have made my research possible. Funding support from the Hedley Donovan Fellowship at the University of Minnesota allowed me to develop my dissertation proposal. I have been extremely fortunate to hold two Foreign Language and Area Studies Fellowships and a Critical Language Scholarships to study Hindi and Urdu, both necessary languages for my research. A generous fellowship from the MacArthur Interdisciplinary Center for the Study of Global Change at the University of Minnesota supported my dissertation research. I also had significant logistical and financial support from the American Institute of Indian Studies. I owe a huge debt of gratitude to Elise Auerbach, for her work in getting me a research visa and to Purnima Mehta for her support through all of my little emergencies in Delhi. The University of 
Oklahoma was extremely generous with financial support for this project, without which several chapters could not have been completed. The Florence Tan Moeson Fellowship administered through the Asian Collections of the Library of Congress provided generous support for research on the introduction of the volume.

I appreciate the institutions of scholarship that have refined my thinking and writing on this project, particularly the anonymous reviewers of two articles that are early versions of some of the chapters in this book. In this book, Chapter 4, "All India Women: Citizenship Politics of the All India Women's Conference," is revised from the article "Constructing Women's Citizenship: The Local, National, and Global Civics Lessons of Rajkumari Amrit Kaur," which was first published in Journal of Women's History 27, no. 2 (2015): 154-175. Reprinted with permission by Johns Hopkins University Press. Parts of the introduction and conclusion were originally published in the article "Ghosts of Indian Unity: Difference, Diversity, and Violence," which was published in Kairos: A Journal of Critical Symposium 2, no. 1 (2017): 67-82.

I have been extremely fortunate to benefit from the teaching and friendships of a number of amazing scholars who have each profoundly changed the way that I think, read, and write, and without whom I would never have been able to complete this book. A sincere thank-you is owed to several scholars who have agreed to read and comment on my work over the years, including (but not limited to) Dipesh Chakrabarty, Geraldine Forbes, Barbara Ramusack, Eleanor Zelliot, Catherine Asher, Rick Asher, Tom Wolfe, Rochona Majumdar, M. J. Maynes, Gyan Prakash, Afshin Marashi, and Allen Issacman. Without the collaboration and support of other scholars in the field, I certainly would have created a far less satisfactory project. Thank you sincerely to Rohit De, Ornit Shani, Dinyar Patel, Katy Hardy, Rachel Ball-Phillips, Arvind Elangovan, Isabel Huacuja Alonso, Venugopal Maddipati, Nadim Asrar, Noah Theriault, Erika Robb-Larkins, Miriam Gross, Daniel Mains, Andreana Prichard Katie Levin, James Zeigler, Victoria Sturtevant, Dylan Herrick, and Jessica Pearson.

My two advisors at the University of Minnesota shaped this book, and indeed my whole approach to scholarship. Ajay Skaria was endlessly patient and encouraging with me. Through thousands of hours of conversations he taught me what it meant to be a thoughtful and careful historian. Simona Sawhney constantly challenged me to say more, think more carefully and slowly, and read more deeply. She always expected me to be better than I was, and in trying to earn her respect I became better than I thought I could be. I entered graduate school with a group of amazing South Asian scholars. Pritipuspa Mishra, Aditi Chandra, Julietta Singh, and Papori Bora were the best academic cohort in the world. Challenging, patient, and fun, they set the bar high for excellent collaborative scholarship and companionship.

When I was beginning my dissertation, I had the extreme good fortune to join up with a writing group that has really been a writing, professional development, emotional support, and friendship group for close to 15 years. Without Aeleah Soine, Rachel Neiwert, Elizabeth Swedo, Kira Robison, and Tovah Bender, I 
would have never finished my dissertation, let alone this book. Collectively they have read almost every word I have written since the middle of graduate school and have worked to make it better, all the while providing me the emotional and mental support to keep going even when I would have given up.

Without my family, none of this would have been possible. Ellen and Gilbert DeBenedetti have been a constant support to me and my family as I have taken time to research, write, and rewrite this book. I want to acknowledge the love, support, and care of parents, Jill Rook and Richard Koepsel. They have always pushed me to achieve my goals in the gentlest way possible, and have never failed to be proud of me. Just knowing that they are always ready to hold me up has made it possible for me to stand on my own. My sister, Megan Parker, has always been the best friend and co-conspirator that anyone could have. She listens to all of my kvetching and preening and never fails to give me exactly the most helpful response. She is smart, funny, kind, and loving and I am glad I have always known her.

My sons, Robert and Simon, are endlessly loving and challenging, and without whom my life would be immeasurably less. They bring meaning and joy to my life. Most importantly, I want to thank my husband Abe, whose love and companionship makes everything possible. He is my best support, my toughest questioner, and my kindest and most loyal friend. He knows when to push me, when to leave me alone, and when to just be there through my craziness. I know I could never thank him enough for being part of my life. 



\section{Introduction}

\section{Becoming All India}

The "All India" prefix became a nearly ubiquitous marker from the 1930s onward. It was used by organizations large and small to mark their commitment to the Indian nation, and has remained a staple of Indian organizations asserting their contribution to Indian unity and defining their place in the Indian state. During the 1940s and '50s, the prefix was common enough that the implications of its use in describing organizations that aspired to be part of a whole Indian state, even in idiosyncratic ways, were well understood - even if widely debated. In January 1941, The Hindu, a moderate newspaper published in Madras, printed a list of new and recurring "All India" conferences as part of its "Year in Review" section. ${ }^{1}$ Editorially, the list was fairly long and included many organizations for which the term "All India" seemed incongruous. The authors of the "Year in Review" section intended to illustrate the shared language with which people across India were responding to increasingly urgent calls for independence, political democracy, and unity. In the 1940s, many Indian organizations focused on their "All India" status to make space for dissent from majoritarian claims about the singularity of Indian identity, while still actively identifying as Indian and connecting their organization and constitutive mission with India. By 1950, the "All India" opener was all but required for new organizations hoping to be included in state planning, to the point that the naming strategy had lost most of its ability to describe an alternative vision of Indian unity.

Like the move toward adopting "All India" in the names of political organizations, naming practices in general were a common strategy for countering the colonial and anticolonial policing of the borders between Indian identity categories of caste, religion, and geography. ${ }^{2}$ Because it was not immediately clear how some communities fit into racial, religious, or caste constituencies, naming and renaming allowed for political and social realignments within the colonial requirement of categorizing people and things. ${ }^{3}$ Artifacts of these colonial management tactics continued in the founding moments of the independent Indian state. When the Constituent Assembly met for the first time in December of 1946, it assigned members both by geographic districts, such as are still in use today, and categorical representatives of constituencies, such as members for Indian women, Anglo-Indians, or Muslims. Because of the enduring legacy of categorical constituency representation in India, the naming and self-definition 


\section{Introduction: Becoming All India}

of categories continues to be important as a way to gain access to political power and responsibility.

The 1940s and '50s were a distinct and distinctly unsettled period in India, where independent statehood was seen as a likely possibility with uncertain effects and outcomes. Indian independence seemed tantalizingly close from the beginning of the 1940s, but World War II, communal rioting, the deadly Bengal famine in 1943, and ongoing vocal disagreements between the Indian National Congress and the All India Muslim League made the structure of a postindependence state seem uncertain. Even after independence was determined upon, the partition of India into India and Pakistan, the Indo-Pakistani War in 1947, questions about the national status of Indian princely state of Hyderabad in 1948, separatist movements in the Northeast Indian states, and the reorganization of Indian states along linguistic lines throughout the early 1950s, meant that even the simplest notion of how India was shaped and who belonged to India was under question. This uncertainty allowed for many different creative reimaginings of the future Indian state and its constitutive ideologies of democracy, unity, and nationality.

This book considers two case studies of All India organizations wrestling with the concepts of democracy and unity in the decades before and after independence: The All India Scheduled Castes Federation and the All India Women's Conference. These two organizations shed light on the way nonreligious minority groups attempted to make a space for specific minority politics in the burgeoning Indian state. Each of these two cases offers a different look at the politics of Indian nation-ness at the beginning of the independent Indian state to argue that, while specific commitments to unity and democracy were required from organizations attempting to engage the Indian nation, the content of those commitments differed. While these two cases by no means represent the entirety of ways that politically minded institutions in the 1940s and '50s claimed democracy, unity, and Indian identity, they give a sense of the depth of debate and unsettled character of these terms. They represented clear, strong voices in the debates about democracy by representing a specific set of ideas or interests that is a gendered minority perspective and a caste-based minority perspective.

The definition of "majority" in India was the ability to define the structure of national unity, and by extension, the identity of the nation. Questions of how "majority" and "minority" were defined with regard to religious and socioeconomic status have long been a concern for those categorized as "minor." The fight for independence saw many shifts in the way that the concept of minority was mobilized. Minority, often thought of in a numerical way, has several other valences, including the minor as a child, the minor as unable to support or represent itself, and the minor as less important than the major. ${ }^{4}$ As Dipesh Chakrabarty points out, "Numerical advantage is by itself no guarantor of major/ majority status." ${ }^{5}$ When considered this way, the idea of majority as representative and therefore defining, and minority as protected and defined by its relation to the majority, gave rise to a system whereby minority actors either were pushed to the margins of the state, or created strategies to define Indian unity differently. 
As will be discussed in Chapters 2 and 3 of this book, the All India Scheduled Castes Federation, a Dalit political party, sought to build Dalit concerns into the Indian state through a radical reimagining of both the terms of unity and democracy. Founded at the All India Depressed Classes Conference in 1942 with B. R. Ambedkar, the face of Dalit politics, as its guiding force, the Federation was operative until 1956, when it was disbanded. As discussed in Chapter 2, All India Scheduled Castes Federation used naming to highlight the political claims of a Dalit minority constituency. Although Dalit politics had been, and continued to be, declaimed by Congress leaders as narrow, communal, and illegitimate, the All India Scheduled Castes Federation argued that recognizing oppositional politics within the multiplicity of separate, but responsive, minority groups would produce a political community unified by a commitment to the state and engagement across identity barriers. By focusing on the state designation of Scheduled Castes, the plurality of castes, the acknowledgment of distinction of Federation, and the commitment to Indian unity embedded in its "All India" name, Chapter 2 shows how the party telegraphed its proposed redefinition of Indian national unity to actively include Dalits as a distinct, politically active, nationally focused minority.

Chapter 3 takes a closer look at the specificity of the All India Scheduled Castes Federation's attempt to redefine democracy and democratic expression in India. The chapter argues that the All India Scheduled Castes Federation identified two problems with democratic expression in India: First the equation of majority defined by personal characteristics (caste, class, geography) on one hand and majority defined by political affiliation on the other, and second the failure on the part of the majority to respond adequately to minority politics. The All India Scheduled Castes Federation very explicitly critiqued European-style parliamentary democracy as failing to recognize minority constituencies as both communal and political, and therefore defining caste as a communal minority that was both apolitical and illegitimate. This chapter shows how the Federation proposed a renewed emphasis for minority political institutions on the basis of reciprocal politics of dissent, and encouraged specific political priorities of respect, responsibility, and engaged citizenship as values that could be used as a platform to build a principled opposition to engage the communal majority.

Expanding on the questions raised by contested minorities, Chapter 4 focuses on the political expression of the All India Women's Conference. The All India Women's Conference was founded in 1927 as an activist organization meant to intervene in issues that had defined the lives of women. Although it was started as a conference for the purpose of addressing women's education from a woman's perspective, within a few years the organization had become one of the primary platforms available to discuss women's political issues and intervene in the local, national, and transnational conception of women's work in India. This chapter argues that the All India Women's Conference's organizational structure offered an insight into the way women activists conceived of and pushed for participatory citizenship at all levels of engagement. Focusing on the concept of locality, Chapter 4 draws on the Conference's attempt to define social work as 


\section{Introduction: Becoming All India}

political action for locally engaged women, while at the same time emphasizing women's role as arbiter of a unified national identity and transnational connectivity to promote space for women's active and vocal participation in the Indian state. Although the All India Women's Conference was resolutely not a political party, nor was it affiliated with any party, the conference pushed to encourage women's politics expressed both through party politics and through nonparty political activism as a way to simultaneously advance the cause of the state and the cause of women's citizenship. Therefore, the All India Women's Conference provided an organizational structure and rhetoric about locality, nationality, and unity that emphasized both the need for a successful independent India, and women's right to democratic practice between 1940 and 1960.

The questions that members and leaders of the All India Scheduled Castes Federation and the All India Women's Conference asked-about the role of state, and specifically central state influence in the production of a unified vision of Indian democracy and nation-ness, about the space of castes constituency as legitimate minority political expression, about the accessibility of citizenship claims for women, and about the ability of marginal actors to dissent from normative nationalist ideals while remaining nationalist voices - expressed some of the concerns prompted by many other nonnormative nationalist organizations in speaking back to a notional, but not fully realized Indian state. While other minority political organizations, especially religiously organized groups like the All India Muslim League, are often singled out as "national" minorities and recognized as different from or counter to the politics of Congress nationalism, women's and Dalit politics were seen, when they were seen at all, as insufficiently separate from the majority to claim difference and representation. Their politics as internal minorities dedicated to Indian nationality and against their erasure as a constituency remains an important part of Indian political dissent today. Of the two organizations, the All India Women's Conference still exerts considerable influence in Indian society today. The All India Scheduled Castes Federation, though defunct since 1956, was taken seriously during its short life by both the British government of India, and by the Indian National Congress as a potential (and potentially dangerous) representative of Dalit political demands, and remains an important early point in the tracing of caste politics in India today.

\section{Naming All India}

As Indian independence became a more likely scenario for both Indian anticolonial activists and the British colonial administrators in the late 1930s and early 1940s, questions about India's capacity for unity and political independence were more stridently asked and more urgently answered by both groups. In response to this "crisis of unity," political activists focused their organizational mission statements, nationalist speeches, and political wrangling on the importance of creating a unified India. For example, when the leaders of the All India Women's Conference rewrote the organizational constitution in 1939, they added a number of clauses that professed the organization's commitment to 
Indian unity. The "All India" ethos was part of this effort. "All India," as a prefix, broadly suggested unity while privileging Indian nation-ness as a common goal.

Perhaps the best articulation of the promise of "All India" unity in politics was provided by a fervent detractor of the idea of Indian unity (and the name "All India" itself). In 1933, Choudhary Rahmat Ali published a pamphlet arguing that the varied religious, regional, and ideological nations of South Asia had been unwittingly co-opted into what he called "Indianism," or the belief as he argued that India was or could be a united nation. ${ }^{6}$ For Ali, the main marker of the virulent Indianism that he argued was taking over in the wake of the Indian nationalist movement was the "high-sounding title of "All India." ", Ali argued, "Now this preposterous prefix of 'All-India' [affixed] to the names of their organizations meant, if it meant anything at all, that though they were Muslims, Sikhs, or Rajpoots, yet they were all 'Indians." "8li argued that the subcontinent should have been properly divided into many different nations, not simply based on a Muslim/Hindu national divide, as had been proposed in many other places, but most particularly in Mohammad Iqbal's presidential address to the All India Muslim League. ${ }^{9}$ Instead, according to Ali, the subcontinent should be properly divided into regional and religious nations, with specific emphasis on distinct cultural heritages and multiple national affiliations. ${ }^{10}$

Ali, imagining that inexpert groups had been duped into accepting India as a single nation, and perhaps even working to further its pretensions toward unity and independence, pointed precisely to the stakes involved in choosing the "All India" prefix. Contrary to Ali's claims of political naiveté, however, many minority political organizations argued that the "All India" name was not a dupe of the majority, but rather a conscious choice by well-informed political actors attempting to engage with Indian national imaginings. The name signaled a commitment to the idea of India that was added to the already present commitment to the community or issue that the organization primarily addressed. In this sense, the "All" was a way for organizations to divert, if not entirely put aside, criticisms of communalism or narrow particularity, while the "India" expressed both a national aspiration and a commitment to the future of the nation at work. Thus, "All India" named the commitment, while the rest of the organizational name indicated the constituency or interest. The name as a whole offered insight on minority organizational politics, because it pointed to the attempt by minority political activists, often dismissed in the traditional national narrative, to include minority concerns in the negotiation of nationality and citizenship.

The commitment to the nation suggested by the "All India" prefix was not the same for each organization, nor did it indicate a sublimation of organizational policies and politics to the majority's goals for the nation. Indeed, at the same time that the "All India" prefix indicated a commitment to the nation, it also suggested an argument for the meaningful inclusion of each party in the work of nation-building. The "All" may have indicated that the group was incomplete without the nation, but it also argued compellingly that the nation could not be constructed without the groups represented by these "All India" organizations. 


\section{Introduction: Becoming All India}

For example, Dhanvanti Rama Rau, the president of the All India Women's Conference (AIWC), in thinking about the All India commitment of her organization argued:

Our Conference can guide not only our members, but women generally, to formulate views on matters of vital importance. At this critical time in our history with political freedom must come great changes in our economic and social life, and the task of regeneration will fall on the shoulders of men and women alike. The majority of our women are so ignorant of the great currents of progress, that the work of educating them to accept the ideals of nationalism and internationalism, of social justice, economic and educational rights will fall on progressive organizations like the All India Women's Conference [which] will play an inspired part and awaken our women to their responsibilities so that they may help to overcome superstition and illiteracy and strive to contribute their share to the general rebuilding of our nation. ${ }^{11}$

Rama Rau argued that while it was the organization's responsibility to commit to the nation, the nation would be incomplete without the work of women for its prosperity. Moreover, for organizations like the AIWC, it was important to note that a responsibility to the nation could not be wholly fulfilled by a responsible majority. The "All," for these minority organizations, indicated an argument about the need to recognize themselves as actors with responsibility - and not just rights - to the nation. Thus, organizations like the All India Women's Conference argued that they could speak to issues outside of the representation of women because their commitment to the nation included a commitment to safeguarding national spaces for minorities. In this sense, the idea of the "All" in the "All India" naming strategy was always in excess of its ability to define an organization. The excessive "All" in some "All India" organizations' names defined the organization and their national commitment, but only with the recognition that they remained an "All" among other "Alls," each with claims to India.

The "India" in the "All India" of groups that functioned as minorities was key to describing their inclusive nationalism. The difference between the exclusivity of their constituency (e.g., Muslims) and the inclusivity of their prefix ("All India") meant these organizations could only be, at best, a part of the Indian unity, and could not dictate its content or function. For these organizations, the "All" described both "India" and the constituency, with the idea being that the All India Muslim League was an organization for "all" Muslims and "All" of India; the Muslim population was no less a part of Indian unity for being Muslim. As such, these organizations, by their very commitment to interior and exterior unity, had to recognize and respond seriously to other "All India" groups who claimed both difference and inclusion.

For this reason, the "All India" prefix, when read against the grain, offered an acknowledgement of the antipathy between unity and minority in India. Ernesto 
Laclau has argued that minority is the "other" required for the construction of a majority, and the terms "minority" and "majority" within the context of the nation are often shorthand to define the complete picture of national identity. ${ }^{12}$ The problem with this structure in India is not only that there is a preponderance of minority identities, or shifting identifications within these identities, but also that the failure to properly name any particular national minority creates a structure in which minority and unity, rather than minority and majority, are antonymic. ${ }^{13}$ The push among minorities attempting to define their role in national life was seen to exacerbate the crisis of unity, because attempts to carve out regional, religious, or linguistic identities as both Indian and separate from the well-established national imagination seemed to point to the ways that Indians felt different from each other rather than emphasizing a sense of national purpose. Thus, Mohandas Gandhi argued, "It is a dangerous thing to emphasize our differences and distinctions." 14 In the Indian case, where many minorities were claiming a stake in the definition of the nation through the identification of their concerns as part of an "All India" movement, the stable footing on which Indian unity could be defined as singular was questioned. The multitude of minority concerns pushed the majority to argue that majority and unity were synonymous, and any attempt to defend minorities as an active partner in national negotiation was pitched as an attempt to derail unity.

Implicitly, the problem was that minority demands for a good-faith effort to include their voices in the negotiation of the national unity and Indian democracy around the time of independence seemed to undermine the majority's story of fundamental equivalences in the needs and desires of the entirety of the Indian population drawn from the claims of real and fundamental unity and surface diversity. Indeed, the Indian National Congress's claim of being able to represent everyone was largely based on the inadmissibility of Indian political difference. ${ }^{15}$ Hence when Jawaharlal Nehru argued, "Whatever the shortcomings and errors of Congress might be it is in conception and even in practice a national movement.... It is essential that there be such an organization. There is no other," he was claiming a right, on behalf of Congress, to police claims to national politics and practice, without recognizing Congress's specific constitution. ${ }^{16}$

Minority commitment to the nation and minority difference, as well as organizational attempts to actively define Indian-ness as inclusive of difference, fractured the uncomplicated national unity story that majority nationalism was trying to create. As the 1940s progressed, minorities were asked either to commit to nation and national unity as defined by the majority, or to remain "non-national," communal forces. ${ }^{17}$ Many organizations chose to reiterate both their commitment to the nation through a redefinition of their "All India" prefix and their dedication to their constituency. While it is unclear for most nonnormative nationalist organizations that whether or not mainstream nationalism had any problem accepting their claims to represent in the nation, the staking of a claim both within the rhetoric of inclusive national identity (All India) and specific constituency, emphasized a concern about the way minorities were perceived in the face of the nation. The political claims of several minority All India groups were 


\section{Introduction: Becoming All India}

structured around a deep commitment to India, and an emphasis on a particularly Indian idea of unity and particularity. Yet, their push against the simpler vision of singular unity, or fundamental Indian-ness seemed to highlight, and perhaps confirm for majority nationalist organizations and colonial administrators the idea that an independent India, with all of its differences, would soon find itself in a crisis of unity.

\section{Crisis of unity and fundamental similarity}

In 1938, Jawaharlal Nehru published an article in the Foreign Affairs magazine called "The Unity of India." In the article, Nehru addressed an American reader who wanted to support Indian nationalism but felt uncertain if the future independent India would be able to maintain national unity sufficient to building a robust and enduring democracy. ${ }^{18}$ Nehru sought to console the American democrat that while his "hesitations [were] natural," ultimately Indian unity had existed for hundreds of years and would continue to exist after independence. ${ }^{19}$ Nehru spent approximately half of the relatively short article detailing all of the reasons to distrust the claims of Indian unity, including the size of the country, the lack of industrialization, the widespread poverty, the influence of colonial rule, the historical failure of full integration of the Indian subcontinent, religious difference, and the superfluity of languages.

Nehru began his last paragraph by pointing to the quantity and quality of work that Indian citizens would need to do to produce a unified, democratic India. He wrote, "In the subconscious Indian mind there is a questioning, a struggle, a crisis," of Indian unity that could be overcome only by "march[ing] wearily through the deserts of conflict, and hatred, and mutual destructions." 20 The crisis of unity, prompted by colonial actors' claims that India could not sustain peaceful coexistence among the members of its diverse population, was both a rallying cry to action and an uncertainty deep in the heart of mainstream Indian nationalism, of which Nehru stands as one of the most well-known luminaries. Thus, throughout the article, he carefully tried to debunk these challenges by arguing that India was at its deepest level, culturally, and socially unified, and that it is, at present, unified by a political desire for independence and democracy. Yet even while arguing that unity and democracy were strongly rooted values in Indian society, based on similar cultural expression and deep historical ties, Nehru acknowledged that religious tensions, communal disturbances, and social isolation could act as challenges to Indian national unity if they were not systematically refuted at every turn. The article is interesting, not for the claims it makes about the fundamental unity torn asunder by bad colonial actors, but for the evident power with which he presents the case for Indian disunity and the discomfort he displays in stating categorically that Indian unity is indeed inevitable. Although Nehru would later write more cheerfully on the subject of Indian unity, emphasizing India as a palimpsest where "everywhere there was that tremendous impress of oneness" in 1942, an underlying wariness and despondency about India's ability to 
sustain national unity among its population pervaded much of the discussion of Indian nationalism from the 1940 s through $1960 .{ }^{21}$

The most common narrative about the political landscape of the 1940s in India remains the two-pronged story of a dominant nationalist movement for Indian independence led by the Indian Congress Party against the British, and the antipathy between the Congress Party representing India and the All India Muslim League representing South Asian Muslims in the call for Pakistan. Indeed, the persistent conflict between the All India Muslim League and the Indian National Congress, and ultimately the partition of India into India and Pakistan at independence in 1947, emphasized the uncertainty associated with the majority nationalism's idea of a fundamental Indian unity. ${ }^{22}$ Moreover, the All India Muslim League's claims to an equal political space for their constituency, through the assertion of Indian Muslims as a separate nation within India, made the policing of expressions of Indian national unity by the Indian National Congress Party more frantic, and their stance toward other minority and marginal populations' political expressions of distinct identities and demands more rigid.

Often in discussions of Indian political minority during the 1940s, the All India Muslim League and the demand for a separate Muslim nation take up all the air in the room, ignoring or undermining other minority political demands for recognition but not for nationhood or separation. While the League's claims are important in defining religious minority in India, they do not represent the entirety of minority politics during this period. ${ }^{23}$ Minority political actors and organizations challenged Congress's claim to represent all Indians along caste, gender, regional, ideological, and class axes among others. Indeed, the crisis of unity pushed many majority actors to claim that any attempt to tweak the concepts of unity and democracy was tantamount to communalism and anti-national behavior. ${ }^{24}$ The portrayal of minority nationalism as anti-national was also a response to the continual repetition by the British that India was held together by the Pax Britannica ("British Peace"), that upon independence and the British withdrawal and cessation of policing Indian difference, India would splinter along religious, linguistic, and regional lines. ${ }^{25}$

Indian politicians and anticolonial activists of all stripes were quick to point out that this much-lauded Pax Britannica was faulty. ${ }^{26}$ They argued vociferously that India had long-standing democratic traditions that had helped to transform invaders into Indians, leading to a fundamental unity despite surface diversity in caste, religion, region, and language. ${ }^{27}$ Anticolonial activists also claimed that what was described as national integration and the peace of the British ultimately cloaked a strong current of colonial divide-and-rule tactics. ${ }^{28}$ Yet, as in the Foreign Affairs article, the insistent claims of fundamental, unshakable, and homegrown unity were undergirded by "questioning, struggle, and crisis" about the depth of Indian unity. Professions of unity, claims of support for democracy, and performative orientations of commitment to the Indian nation and its state were demanded from any organization seeking a voice in Indian politics, both internally from the membership of organizations, and externally from other, 
more politically powerful groups. Politicians from majoritarian political organizations policed these professions of commitment to unity, democracy, and the Indian nation for any sign of wavering or uncertainty. ${ }^{29}$ Importantly, minority and marginal constituencies also used the rhetoric of a crisis of unity to emphasize their own commitments to a big-tent Indian nation.

Despite the somewhat rigid requirements of proofs of commitment to the Indian nation, the Indian state, and its structures, the terms of Indian-ness, unity, and democracy were also opportunities, especially among nonnormative nationalist organizations, such as the All India Scheduled Castes Federation and the All India Women's Conference seeking to claim a space for themselves in a future independent India. For example, while claiming democratic values were ideal and indeed natural to India, an organization or political party could also ask what democracy meant ethically, socially, and economically; it could push for democratic structures that were more or differently representative, as the All India Scheduled Castes Federation did. It could argue for recognition of everyday, local, and small-scale efforts as part of a national story of democratic work, a primary claim of the All India Women's Conference. Because the Indian nation and the Indian state remained in flux during the 1940s and '50s, marginal political actors, writers, social activists, and others were able to propose new ideas about what it would mean to be a unified state that focused on political responsibility, respect for difference, and a more inclusive way of defining the Indian population. These debates suggest that investment and meaningful participation in questioning a uniform national identity continued long after India is generally regarded to have solidified its national identity and state structure, and continue to influence the way dissent is registered, organized, and responded to by the Indian state.

\section{Democracy debates}

In 1954, more than seven years after Indian independence, J. P. Narayan, a leftleaning politician and well-known activist, asked in the inaugural series of All India Radio's National Programme of Talks called "The Challenge of Democracy" how the Indian people could envision democratic values to suit the specificity of life in India. He characterized democracy as an essential, but also essentially flawed, political ideology for the Indian state, and posited that the parliamentary style of Western democracy supported elite, majority politics instead of responding to, or even respecting, different perspectives and political visions. Narayan argued that Western democracy's structure disengaged marginal populations in relatively homogenous and wealthy states with a long history of evolving the concept of democracy for statecraft. Thus, he pointed out that democracy survived in Europe not because it had been so successful in engaging the population and building democratic values into economic exploitation, but because industrialization had brought a continual, if low-level, rise in the quality of life of the lowest subjects, while allowing for greater freedom among the citizens of the state. Even in Europe, and especially in newly 
independent states, he also critiqued "modern democracy" as being tied as much to the "growth of economic inequality, exploitation, unemployment, and imperialism" as to the "enlargement of freedom." 30

According to Narayan, what was required in India specifically, and Asia in general, was a refigured vision of democracy that was quick to engage Indian citizens in explicitly Indian ways. Specifically, Indian democracy needed to be attentive not just to forms and practices of democratic statecraft (e.g., voting), but also to economic and social equality among all its potential citizens. Functionally, Narayan's argument was that India wisely chose democracy as the bedrock of its new independent state because it connected with a cultural and political desire for respect and freedom. ${ }^{31}$ Reflecting a general feeling of unease in India that the country was economically, geographically, religiously, and culturally disconnected, Narayan argued that democracy, as a concept, offered the most potential for unifying the Indian state, but that it needed to be reformed from the bottom up in order to accommodate Indian difference in the creation of a plural Indian national society. ${ }^{32}$ As he argued, "From the village upwards to New Delhi and from bullock farming to major industries, forms of selfgovernment will have to be evolved which will form essential parts of our democracy." $" 33$

Spoken from the national center of state-owned and state-operated radio, the voice of the inchoate state, and with a critical take on India's democracy thus far, the Narayan All India Radio talk emphasized three important points about the functioning of Indian democracy. First, it pointed to the strong sense that despite having other options for state organization, democracy was still imagined to be the best option for the Indian state. Second, that democracy, even after the enactment of the Indian constitution in 1950, was by no means a settled concept; it remained in a state of flux, capable of being renegotiated through both public and political debates. ${ }^{34}$ Third, that the debates about the role of democracy in the Indian political system were not merely the privilege of majority politicians looking to tweak slightly the state's vision in India; political debates often focused on the need for democratic reform with an oblique eye to the role of marginalized populations, and the quest to define its own democracy persisted throughout India's media, civil society organizations, political parties, and popular culture.

Politicians and activists assumed democracy in some form to be the future system for Indian home rule as early as the founding of the Indian National Congress in $1885 .{ }^{35}$ For many organizations, political or otherwise, a claim of support for democracy, or more broadly, democracy and democratic principles, functioned as a signal of support for nationalism. ${ }^{36}$ Even political figures who have long been claimed as supporters of totalitarian government, such as Veer Savarkar, presented themselves as democrats in speeches and organizational constitutions. ${ }^{37}$ Yet the purpose, structure, ethics, and manifestations of a future democratic India were far from clear. Many politicians, organizations, and public figures simply asserted a preference for democracy and moved on. But many others, including but not limited to the actors and organizations considered in 


\section{Introduction: Becoming All India}

this book, actively engaged with the question of what a specifically Indian democracy would entail. The idea of democracy, especially a democracy that could be crafted to be Indian, continued to be a cornerstone of Indian political expression in the absence of a certain and enduring definition. ${ }^{38}$

Structurally, the democracy debates allowed for a kind of national exploration of democratic values that emphasized some of the differences in the way democracy as a political philosophy was seen in India compared to other parts of the world. Leela Gandhi has argued that one of the distinguishing factors in thinking about a theory of postcolonial democracy was a removal from the liberalizing tendency toward perfecting concepts and ideas. Thus, the postcolonial democratic ethic was one that functioned with imperfectability at the core of its exploration. ${ }^{39}$ Other scholars commenting on Indian democracy have argued that the tenacity of the debate about the structure of democracy appropriate to India arose from strong group-rights interests in the participation in the potential Indian state, combined with the recognition of uncertainty about their welcome in a potential new state. ${ }^{40}$ In particular, this book focuses on the ways in which the All India Scheduled Castes Federation and the All India Women's Conference recognized democracy's potential as both a space for further exclusion and a vehicle for better access to social, economic, and political equality. It suggests how these two minority-rights organizations made the reevaluation of the meaning of democracy important, while the unifying call for democratic government made it palatable to majorities. As India began to seriously contemplate national independence, the state and political actors were "tolerant of ambiguity," especially where ambiguity of meaning was translated into a common goal beyond mere dislike of the colonial state. ${ }^{41}$

\section{The expectation of unity in democracy}

In December 1946, Jawaharlal Nehru presented an opening resolution for the Constituent Assembly, the body that was appointed to draft India's constitution and oversee the transfer of governance from a colonial government to an independent Indian state, that India should be an "independent, sovereign republic." Quickly asserting that no debate could be mounted either about the desirability of independence or about the necessity of independent India's sovereignty, Nehru spent much of the rest of his speech explaining why he chose "republic" as one of India's primary distinctions. Dismissing the idea of instituting a monarchy as infeasible and retrograde, Nehru took up the question of why not democracy:

Now, some friends have raised the question: "Why have you not put in the word 'democratic' here?" Well, I told them that it is conceivable, of course, that a republic may not be democratic but the whole of our past is witness to this fact that we stand for democratic institutions. Obviously we are aiming at democracy and nothing less than a democracy. What form of democracy, what shape it might take is another matter. The democracies of the present 
day, many of them in Europe and elsewhere, have played a great part in the world's progress. Yet it may be doubtful if those democracies may not have to change their shape somewhat before long if they have to remain completely democratic. We are not going just to copy, I hope, a certain democratic procedure or an institution of a so-called democratic country. We may improve upon it. In any event whatever system of government we may establish here must fit in with the temper of our people and be acceptable to them. We stand for democracy. It will be for this House to determine what shape to give to that democracy, the fullest democracy, I hope. ${ }^{43}$

Nehru concluded that democracy was unnecessary to a resolution on the opening of the Constituent Assembly because democracy was "obviously" the aim. He affirmed this in part because nationalism in India relied on a rallying cry of democracy as a base point for independence, and in part because "the whole of our past is witness" to Indian affinity for democracy. ${ }^{44}$ It is in this claim of India's natural affinity for democracy that Nehru's discussion of democracy both acknowledges the debate around the structure of democracy, and co-opts it through a sense of Indian exceptionalism. For Nehru, as for other activists advocating democracy, India presented a singular case that required a unique democratic structure. Yet for Nehru, the question remains: How can we make a democracy that is defined not by European history, but by a largely undifferentiated Indian past?

Nehru's resolution and his argument for the necessity of a particularly Indian democracy echoes claims by Indian anticolonial activists that Indians were fundamentally democratic, based on the notion of Indian history as a succession of integrations of new populations in the subcontinent. The idea of a welcoming Indian culture functioned as a way to refer to the democratic character of diversity within the national concept of India, as well as making mainstream the calls for an Indian definition of the term. By claiming that Indian history dictated democracy as proper to India, Nehru used this moment as an opportunity to reclaim a conceptual rethinking about democratic structure that had previously been argued primarily by minority and marginal political organizations.

The question that Nehru raised at the opening of the Constituent Assembly"What form of democracy?"-was, in effect, a restatement of the kind of questioning that "an Indian Christian" asked in the "Minority Corner" column of the All India Muslim League-affiliated newspaper, Dawn, at the beginning of 1946: "Is the Anglo-Saxon type of democracy suited to Indian conditions or not?" 45 An Indian Christian was reminding all of those organizations clamoring for democracy in independence that democracy as commonly practiced placed minorities, whether political or communal, under the control of majority sensibility for their safeguards and participations. ${ }^{46}$ Firmly placing the query about the structure of democracy in India in the hands of "Minority Corner" and an Indian Christian reflects the way that minority concerns drove debates about expansive democracy through the 1940s. In Nehru's hands, however, the question was more about making a claim to a legitimate national history, in which a specifically 
Indian ethics of democracy was entwined with a fundamental similarity across Indian diversity ${ }^{47}$ In this way, majority representation of minority reworking of democracy required a commitment not to the Indian state or nation, but to the majority representation of Indian-ness. Indeed, the sense of affinity for democracy is still prevalent in scholarly discourse on Indian democracy, and the focus on a national democratic character functions as a fine-tuning of Indian identity and belonging. ${ }^{48}$

Yet, considering the Constituent Assembly response to Nehru's call for a distinctly Indian democracy and the debate about democratic values over the next three years until the ratification of the constitution, the attempt to rethink the questioning of democratic structures into a reification of majority politics was undermined by a thorough examination of the ethics and practice of an Indian democracy. Looking at the debates about the ratification of the constitution in the Constituent Assembly, it is clear that members of the constitution committee saw the Constituent Assembly as modeling Indian modes of democratic engagement. One of the best examples is the discussion by Frank Anthony, a member representing the Anglo-Indian community, describing the committee's discussions:

We have ranged through the whole gamut of democratic factors; there has been careful thought; there has been close analysis; there has been argument and counter-argument; there has been fierce controversy and at one time I thought that the controversy was so fierce that we might reach the stage of what the Romans called Argumentum ad baculum; that is, settling it by actual physical force. But in the final analysis has pervaded a real sense of accommodation and a real feeling of forbearance. ${ }^{49}$

For Anthony, the question of democracy was both about conceptual inclusion and also about the space to perform what he called earlier "the processes of democratic manufactory. ${ }^{, 50}$ Democracy functioned not only as a clear perception of the good of democratic action (thoughtful, analytic, argumentative, and ultimately accommodating), but also as a negotiation of needs and wants across many spaces, something requiring accommodation and forbearance. There were several specific ways that minority organizations tried to pragmatically enforce a unifying democracy for India as Anthony described that recognized and respected minority safeguards and participation, pushed to engage the state across class and geography, and made marginal constituencies into equal citizens, depending on the organizations' aims and populations.

\section{Belonging, minority, and citizenship in democracy}

One way to understand the complicated relationship between Indian minority groups and the Indian nation is by thinking through the sometimes-contentious relationship between the Indian nation and the Indian state. In her article about nationalism and the Indian flag, Srirupa Roy argues, "The articulation of nationhood contains within it a particular understanding of the state (or of the question 
of institutional authority in general)." ${ }^{.51}$ In any profession of commitment to the nation, there exists recognition of the need for a state, and perhaps more importantly, an expectation that participation in the state can help define the nation. Thus, the potential for the post-independence state and state machinery represented the kind of material good that national identification and agitation could produce. The institutions of state, and the call to be included in the reestablishment of those institutions after independence, were important because the state was seen to physically and socially represent the conceptually defined nation. Indeed, in the quest to wrangle the nation into a definable body, the state had to realign the imagination of India and Indian-ness into specific services and representations of diversity and unity. ${ }^{52}$

Although minorities and marginal players were willing to invest in anticolonial nationalism, it was not clear what citizenship benefits their participation translated to, if any. In the immediate post-independence period, the new Indian state needed to be flexible in the way it defined citizenship, borders, and belonging because the state required a relatively significant buy-in in order to successfully transition away from colonial governance. Often, especially for minorities, active citizenship was refigured by the state into a referential relationship. Minority political and social organizations were urged by the government to bring their grievances to political parties in power, and accept safeguards and welfare resources in return, rather than seek to actively engage in the state. ${ }^{53}$

For potential minority citizens, the engagement of the state through the quest for services and resources was both necessary and counterproductive. The idea that resources could serve as proxy for recognition of the minority place in the national story - as indeed they often did in the immediate post-independence period — only served to highlight the "not-quite" status of the minority citizen. Resources as recognition of majority care served to structure the minority as both unable to support their own difference, and fundamentally part of the majority's vision of the nation, and as such, the vision of a fundamental, naturally defined Indian unity. Minority organizations, especially in the lead-up to independence, were striving for resources, but also for recognition and responsibility. Organizations like the All India Scheduled Castes Federation and the All India Women's Conference wanted to invest in a potential national unity that accorded them a place of responsibility. Indeed, not content with a kind of fragmented national identity, many minority organizations were looking to reframe the vision of the nation, seeking to define it by its commitment to including minority and majority populations as active citizens without distiniction; as a state that did not marginalize minority efforts for responsible action by resorting to back-dooring minority citizenship through resource allocation.

Majority organizations like the Indian National Congress, especially when considering the relationship between provincially organized Congress branches and the national organization, were often diverse in both their membership and their governance style and beliefs. Yet the attempt to draw together a single, unified vision of the nation, defined by a specific, normative Indian citizen, made organizations representing nonnormative citizens, (religious, class, sex and 
gender, or caste minority groups), concerned about their place in India should foundational terms like Indian unity and Indian democracy go unchallenged. ${ }^{54}$

Unwilling to take on the stigma of being asked to affirm that the term "Indian" meant a specific identity that they would always be on the margins of, the two organizations discussed in this book emphasized their responsibility for creating an Indian identity that, far from being fragmented, was invested in unity and difference, but not in a fundamentally singular way of being Indian. These organizations attempted to claim their constituency's role as a distinct part of a negotiated Indian nation, and their own role as participants in the production of the state machinery that would invest minority citizens with equal responsibility in running India.

The issue of political minority has often been overlooked with regard to constituencies who were integral to the majority yet subaltern to the society, such as women or Dalits..$^{55}$ The strategies involved in defining democracy differently were necessarily distinct among different minorities, because these strategies needed to take into consideration the specific ways that the constituency was considered "not-quite" Indian. For the All India Muslim League, for example, their insistence on an Indian/Muslim nation was indicative of a rethinking of the politics of state (or "brute majority," as Muhammad Ali Jinnah famously called the Congress party in a speech before the Constituent Assembly), but not necessarily a rethinking of the politics of recognition. ${ }^{56}$ In part this is because, although often troublingly discriminatory, the distinctness of Muslim politics was almost never disputed seriously. In many situations, Muslims and other religious (and ocassionally regional) minorities were seen as enough "not-Indian" to sometimes be more than just "not-quite" Indian. This recognition of distinctness mattered to the All India Muslim League critique of and advocacy for democracy, because it meant that as dismissed as their concerns often were, they were also seen as legitimately "other" enough to raise public concerns as an entity entirely distinct from the Congress and the religious Hindu majority. For Dalits and women, however, the appropriateness of calling their politics a form of minority politics was (and often still is) under debate. ${ }^{57}$ Dalit politics of the 1940s, led by the All India Scheduled Castes Federation, had to wrestle constantly with the idea promoted by the Hindu majority that they were in fact not distinct from the majority, and that as such their concerns were internal to majority politics rather than distinct and could be dismissed as an internal matter. Similarly, the All India Women's Conference had to deal with claims that their constituency was simultaneously both too dispersed and not functionally separate enough from the majority. The closeness perceived between these two minorities and the majority made their redefinitions of democracy more subtle but just as necessary as those of the All India Muslim League, because they defined for the state and the nation difference within itself.

Conflicts that arose immediately after independence, especially partition, allowed the new government to challenge its citizens' loyalty to the nation, support claims of conservative national values, and attempt to actively pursue a singular vision of "Indian values." 
organizations, such as the All India Scheduled Castes Federation, made to promote their joint interest in the constituency and the nation were, in the wake of partition, labeled as communal or provincial, leaving minorities in exactly the position that the "All India" naming strategy was trying to prevent. These moves solidified the "not-quite" status of many Indian citizens in a reading of their own national identity.

\section{Unity and nation-ness ${ }^{59}$}

One of the problems with mainstream nationalistic articulations of Indian unity, like those articulated by many Congress leaders, was that it created a vision of Indian-ness that either failed to consider minority ideas of the nation or failed to conceive of minorities in the national story. The nationalist narrative of Indian history often started with Aryan, Sanskrit, and Vedic Hinduism and ended with India at the time of publication. In this vision, people living in the South, speaking non-Sanskrit-derived languages, tribal peoples, Dalits, and non-Hindus just did not fit in the Indian imagery. Still, the nationalist movement tried to include these "outliers" as part of the rhetoric of the Indian nation by arguing that India had "diversity in unity." The problem was that the nationalist vision of unity was a conflation between a fundamental homogeneity, though admittedly overlaid by diversity, and the idea of unity. ${ }^{60}$ Indeed this concept of a mocked-up unity and diversity claim is one that seems to be resonant throughout the postcolonial world, with many other postcolonial countries using similar slogans. ${ }^{61}$ Although at pains to deny it, in the Indian nationalist vision of the nation, minorities were Indians disguised as something else, but in the minority reading of these nationalist histories, minorities were "not-quite" Indians, defined as much by their poor fit into the national story as by their commitment to the nation that story was supporting. ${ }^{62}$ In a sense, the national minority could only be defined as "the remainder" of the Indian nation: Part of the nation, but outside the nation's own mythos. ${ }^{63}$

The connection between history and the production of the state has long been postulated for precisely the reason that Indian history was complicit in the discussion of state-building. National identities are not natural, but drawing them back to into time immemorial makes them feel as if they were. ${ }^{64}$ The problem with history as a statist enterprise is that writing history to define the nation fundamentally writes some people out of history. The move to recognize the importance of the state in framing and writing history, even of peoples often excluded from state rhetoric, has been an important tenant not just of Indian history, but also of postcolonial studies across the globe. ${ }^{65}$

While a history of Indian unity written by historians falls well within common attempts to create a unified national identity, and into the broadly statist mission of historical studies in general, the historicizing of Indian unity was not confined to the pens of historians. Discussions of literature, music, and art often began with the long history of a particular idea of India's culture. ${ }^{66}$ At the same time, political causes, such as women's rights and reform, couched their own demands 
with a claim that Indian women (and in this claim Indian women meant uppercaste Hindu women) had been far better off in ancient times than they were in the late nineteenth and early twentieth centuries. ${ }^{67}$ To many anticolonial activists in the 1940s, national independence, if it could be achieved well, seemed like the solution to the problems of repression, injustice, and poverty that plagued the country, because it followed as the likely fulfillment of Indian history. ${ }^{68}$ Yet it was clear to many that the success of the nation, the achievement of a "good" independence, depended on the near-universal decision that India was capable of being unified in the colonial present; hence the number of repetitions of the fundamental historic unity of India. ${ }^{69}$

Still, a strong discussion of the fundamental unity of India was troublesome, and not merely because of strong inclinations toward nonnational identities, but also because of the failure of the narrative to account adequately for its own claims of inclusivity. The narrative of prehistoric similarity and the penchant for inclusivity often started - as Jawaharlal Nehru's memoir of a nation, Discovery of India, does - by recognizing the diversity in Indian life. This recognition is a necessary beginning, because it places the colonial critique of Indian misadventure with unity within the claim to intrinsic unity. Yet the recognition of distinctness is often quickly subsumed within a narrative of sameness. ${ }^{70}$ Difference, then, functioned in one of two ways: Either as a spice added to the stew, or as a scheme on the part of the colonial power to undermine India's ability to function like a nation. Especially among minority historians, the impetus to claim a unified history, particularly in the face of historical conflict, meant that difference had to manifest as diversity, and diversity had to manifest as trivial, and as something that could be overcome, as in the idea of "gradual unity." "71

The result of the unifying of historical narrative for the purpose of the state was that irreconcilable difference became the perversion of the natural history of the state. Anyone who felt left out of the narrative was seen to be at fault for his or her own disengagement from the state. As B. R. Ambedkar claimed in his book Pakistan or the Partition of India, the sense of Indian cultural and historical unity was only a powerful inducement insofar as it readily engaged the population. ${ }^{72}$ Thus Ambedkar argued that if the All India Muslim League persisted in demanding Pakistan, there was not a space for unity within India, because an India that included activists for Pakistsan was not a possible event. ${ }^{73}$ What did seem possible, for many of the minority and marginal organizations, whose differences were often denied by the majority-created histories of the Indian state, was a negotiated unity based on the very enlargement of Indian citizenship that Ambedkar implied, a unity for which the foundation was not similarity but commitment.

The concerns about Indian unity functioned as an effective rallying tool for anticolonial activists trying to create a more effective argument against British colonial rule. Congress and its allies argued that British policies (such as the census and land taxes), as well as British politics, encouraged religious and regional groups to organize separately and to negotiate with the government separately. ${ }^{74}$ Congress pointed out that the British policies were enacted to define 
people by their differences, so that various groups would be less likely-even less able - to work together or see each other as similarly Indian. These fissures allowed the British to continue to claim the intractable difference in India and would encourage a continuation of colonial rule there. Congress and other anticolonial activists often cited divide-and-rule tactics to describe communal and regional disputes. Implicitly, the argument made by anticolonial activists was that recognizing divide-and-rule tactics for what they were then allowed for "communities, interests, and political leaders" to set aside divisive colonial practices and affirm their commitment to Indian independence. ${ }^{75}$

Many scholars across several colonial contexts have recognized that nationalism constitutes exclusion and that this exclusion is often made in terms that are broadly recognized as "majority constitutive group" and "minority other." is certainly the most common way that Indian nationalism has been described. Focusing on contemporary (or historical) effusions of Hindu nationalism, Gyan Pandey has argued that Indian-ness was prefaced on making the majority national and the minority somehow suspect or not-quite Indian enough. ${ }^{77}$ National identity is therefore often defined as "majority identity," expansively defined. This is as much the case in India as elsewhere, and as Dilip Menon argues the Indian citizen continues to be imagined as northern, light-skinned, male, and upper-caste Hindu. ${ }^{78}$ Still, this does not mean that men and women outside this picture were uninterested in the project of building a nation that could include them more intimately.

Minority attempts to create an Indian nation inclusive of minority identities were seen both in their rejection of the trite Indian unity and in the challenge to establish a democracy that was interested in unity defined by both minority and majority. Yet Indian independence did not automatically make minorities into normative citizens, and the affirmation of any serious consideration of difference as an internal throwback to colonial hegemony made rethinking unity as negotiated or democratic difficult. Some Indian nationalist organizations, and especially Congress, were unable to think about how unity could be defined in such a way as to allow difference to be fundamental; as a result, the crisis of unity continued as a national motif. ${ }^{79}$

\section{On the meaning of democracy}

Organizational actors expressed a commitment to democracy and Indian nationhood that engaged with the crisis of unity, whose foundations were laid by colonialism, strengthened to a panic by partition, and finally consolidated on the backs of marginal populations. Democracy, especially the vision of an ethical or substantive democracy, was aspirational for minorities long trained to imagine themselves as contingent to the majority for their rights and duties. As All India organizations began to name their commitments (unity, nation, constituency, all negotiated) and make them their creed, the refiguring of democracy from an exclusionary term to an inclusionary one was an attractive strategy. What exactly did these attempts to shake the term "democracy" loose from its bonds to liberalism, individualism, and 
majority entail? It had to be more, certainly, than a refining of procedures and policies, and more than a simplistic vision of national exceptionalism that built upon a rhetorical desire for equality. Rather, the redefinition of democracy was seen as a fundamental realignment of how the Indian nation and all the commitments inherent in its possibility could be combined with the functionality of the impending Indian state. Interestingly, one of the ways that democracy was being interrogated was at the level of practice. This is to say, the protests were not simply to make large-scale changes to the structures of the state, but also spoke to the way that actors in the state represented democratic practice.

Even before independence, debates about such topics as the purpose ascribed to democracy, the content of existent democratic institutions, and how to structure an Indian democracy began to intensify. B. R. Ambedkar examined both the promise of and the objection to democracy in a speech he gave at the Second Round Table Conference in 1930-1931. Ambedkar, a delegate to the minorities committee at the talks, "handed in" a speech toward the end of deliberations advocating separate electorates for Dalits and other minority populations, in an effort, as he explained, to make potential regional and central governments responsive to underrepresented minorities.$^{80} \mathrm{He}$ argued that the function of the roundtable was to think about the administration of India in such a way as to "organize the political life of a community" to function as a both responsible and representative government to all of its citizens. The implication in the speech was that states should be responsible to citizens' welfare and representative of their voices. ${ }^{81}$

Ambedkar saw his role as supporting a government that was representative of the participation of the masses, and in particular the depressed classes, through mechanisms of inclusive governance, properly described as a democracy ${ }^{82}$ Yet he was not content with a democracy that promoted representation among the majority but only safeguards and resources for minority and marginal populations. Instead, Ambedkar argued that democracy was acceptable only so far as it could be reconsidered to make real the prospect of "one man, one value" socially, politically, and economically in India. ${ }^{83}$ Ambedkar specifically focused here on the expansive question of the broad role of democracy to extend each individual equal value, not merely in terms of equal votes, which both undervalued minority representation and failed to recognize democracy's more expansive potential. Structurally, Ambedkar was arguing for separate electorates for Dalits, which in his argument would allow for greater representation of Dalits in government, and for greater potential for making social and economic democracy more feasible in India.

Interestingly, Ambedkar himself made this distinction clear in his more famous speech to the Constituent Assembly on the passing of the constitution in 1949:

In politics we will be recognizing the principle of one man, one vote and one vote, one value. In our social and economic life, we shall, by reason of our social and economic structure, continue to deny the principle of one man, one value. ${ }^{84}$ 
The principle of universal suffrage, one of the mainstays of Congress's democracy promises, was delivered almost immediately upon independence. Ambedkar was pointing to the broader hope of, indeed the more expansive requirement for, democracy in India. ${ }^{85} \mathrm{He}$ argued that simple suffrage assured only base political membership in society. Indeed, the idea of "one man, one vote; one vote, one value" functions as a mode that divorces political freedom from mass equality, emphasizing Chantel Mouffe's claim that democracy is often used to forward two fundamentally different values - freedom and equality-without recognizing their incompatibility. ${ }^{86}$ In some ways, then, universal suffrage was meant to accomplish democracy with moderate aims toward equality and radical aims toward independence. ${ }^{87}$ Without a similar commitment by the state to encourage social, economic, and structural democratic change, however, democracy would be in name only. ${ }^{88}$

Christine Keating points out that there were several ways that democracy structured by a simple affiliation with Western concepts was questioned during the construction of the Indian constitution, many of which pitted radical interests against each other. She argues that the Constituent Assembly used a conception of an inclusive Indian democracy as a showpiece in the creation of a "postcolonial social contract." 89 The postcolonial social contract was not fully articulated and propagated throughout the constitution, nor was it equally thick in its protection of marginal populations, particularly for women..$^{90}$ The recognition in the fundamental freedoms section of the constitution of full citizenship rights regardless of caste, class, sex, religion, or region marked the document as radically admonishing colonial strictures attempting to define partial or underdetermined citizenship broadly. ${ }^{91}$ Indeed, recent descriptions of state violence or state neglect in Naxal regions as "fundamental unfreedoms" taps into the kind of broad redefinition of democracy characterized by respect and radical equality that many scholars of the Indian constitution point to as the guiding promise of the fundamental freedoms section, which is being structurally undermined by exclusionary state practices, unequal treatment of citizens on the basis of place, religion, sex, and/or caste, and lack of recognition for every citizen's one value. $^{92}$

While the divide-and-rule tactics of the British government of India were both real and injurious to the idea of a unified India, the argument for the effect of divide and rule is somewhat less clear. Mainstream nationalism, led by Congress, focused on divide and rule to suggest that the best chance to witness India unity was the fight for independence, and it assumed that because the British helped to manufacture and encourage separate lifeworlds in the communities, regions, and political affiliations of India, these differences were superficial and ultimately scurrilous. The concern that the movement for independence was the only way to effectively describe Indian unity was one of the major contributing factors to the "crisis of unity." When independence failed to produce a clear vision of India as a unified nation, the nationalists were forced to wrestle with the causes of this failure. The easy answer was that the failure to achieve Indian unity was the result of the after effects of colonial domination. ${ }^{93}$ This claim, 


\section{Introduction: Becoming All India}

while certainly at least partially true, threatened to make any attempt to be more interested in minority political expression into a move that reinscribed colonialism into the nation by reaffirming colonial divide-and-rule categories. ${ }^{94}$ Thus after partition in India many centrists and even several high-ranking Congressmen saw working with minorities, and especially Muslims, as tantamount to disloyalty to India. ${ }^{95}$

The need to engage beyond their constituencies forced minority All India organizations like AISCF and AIWC to ask pointed questions about democracy, unity, and Indian belonging that allowed for the democracy debates discussed. They argued that their organizations, by their "All India" commitment, had the right to be considered in more than just an ancillary position. At the same time, their awareness of their own inability to create the "All India" prefix that defined the whole of India caused several of these "All India" groups to propose new kinds of democratic politics in order to define unity along more broadly ideological lines. Some "All India" organizations couched their commitment to the nation as a focus on local action, while others suggested a democracy was created not in the actual end result of legislation but in the commitment to constant negotiation based on a commitment to freedom and unity expansively defined. Underlying each of these attempts to redefine the nature of democracy was an argument about the way India, differently defined, could be reborn as "All India."

Democracy and Unity in India focuses on the All India Scheduled Castes Federation and the All India Women's conference as two All India organizations that came at the democracy and unity debated through a complicated set of issues. Both organizations recognized that they could not, and did not, exclusively speak for the entirety of their constituency across political and social lines. Neither organization sought to be the "sole spokesman" for their group, in part because both organizations recognized that their constituency was broad and at times at odds with itself. Yet both organizations attempted to acknowledge the insufficiency of their representative character within the context of working toward an understanding of general insufficiency of universal representation. In the next several chapters, this book will attempt to consider the strategies that both organizations used to rethink ideas of unity and democracy.

\section{Notes}

1 "A Review of the Various All India Conferences," The Hindu, January 13, 1941.

2 Bernard S. Cohn, "The Census, Social Structure and Objectification in South Asia," in An Anthropologist among the Historians and Other Essays (New Delhi: Oxford University Press, 1987), 224-254; Aamir Mufti, "Orientalism and the Institution of World Literatures," Critical Inquiry 36, no. 3 (Spring 2010): 458-493, especially 481-488.

3 Rosinka Chaudhuri, "The Politics of Naming: Derozio in Two Formative Moments of Literary and Political Discourse, Calcutta, 1825-31," Modern Asian Studies 44, no. 4 (2010): 885; Assa Doron, "Caste Away? Subaltern Engagement with the Modern Indian State," Modern Asian Studies 44, no. 4 (2010): 760. 
4 Dipesh Chakrabarty, Provincializing Europe: Postcolonial Thought and Historical Difference (Princeton, NJ: Princeton University Press, 2000), 99-113, especially 100-102; Gyanendra Pandey, "Can the Muslim be an Indian?," Comparative Studies in Society and History 41, no. 4 (October 1999): 608-629; Faisal Devji, "The Minority as Political Form," in From the Colonial to the Postcolonial: India and Pakistan in Transition, ed. Dipesh Chakrabarty, Rochona Majumdar, and Andrew Sartori (New Delhi: Oxford University Press, 2007), 85-95; Faisal Devji, "Hindu/Muslim/Indian," Public Culture 5, no. 1 (1992): 1-18; Anupama Rao, "Ambedkar and the Politics of Minority: A Reading," in From the Colonial to the Postcolonial, ed. Dipesh Chakrabarty, Rochona Majumdar, and Andrew Sartori (New Delhi: Oxford University Press, 2007), 137-159; Shahid Amin, "Representing the Musalman: Then and Now, Now and Then," in Subaltern Studies XII: Muslims Dalits and the Fabrications of History, ed. Shail Mayarom, M. S. S. Pandian, and Ajay Skaria (New Delhi: Permanent Black, 2005), 1-35; Zoya Hasan, "Minority Identity, State Policy, and the Political Process," in Writing the Women's Movement, ed. Mala Khullar (New Delhi: Zubaan, 2005), 202-217.

5 Chakrabarty, Provincializing Europe, 100.

6 Choudhary Rahmat Ali, "What Does the Pakistan National Movement Stand For?," in Complete Works of Rahmat Ali, ed. K. K. Aziz (Islamabad: National Commission on Historical and Cultural Research, 1978), 15. Ali published three editions of this pamphlet; the final edition was published in 1942 and, unlike the other issues, distributed in South Asia. It is worth noting as a side bar that the pamphlet's distribution in 1942 came two years after the Lahore resolution that declared the All India Muslim League's commitment to securing Pakistan (whose name also comes from Ali, initially).

7 Ali, "What Does the Pakistan National Movement Stand For?," 15.

8 Ibid.

9 Ibid., 19-20.

10 Choudhary Rahmat Ali, "The Millat and Her Ten Nations: Foundation of the AllDinia Milli Movement," in Complete Works of Rahmat Ali, 158-160.

11 Dhanvanti Rama Rau, Roshni Special Number (1946).

12 Ernesto Laclau, "Subject of Politics, Politics of the Subject," differences: A Journal of Feminist Cultural Studies 7, no. 1 (1995): 145-164.

13 For a discussion of the politics of shifting identification, see Arjun Appadurai, Modernity at Large: Culture Dimensions of Globalizations (Minneapolis: University of Minnesota Press, 1996).

14 Mohandas Gandhi, "The National Flag," in Collected Works of Mahatma Gandhi, vol. 48, 21 November 1929-2 April 1930, (New Delhi: Ministry of Information and Broadcasting, 2000), 352.

15 Faisal Devji, "Nationalism as Antonym of Communalism," The Hindu, December 19, 2014; Sumit Sarkar, "Indian Nationalism and the Politics of Hindutva," in Making India Hindu: Religion, Community, and the Politics of Democracy in India, ed. David Ludden (New Delhi: Oxford University Press, 2005), 275-276.

16 Jinnah-Nehru Correspondence including Gandhi-Jinnah and Nehru Nawab Ismail Correspondence (Lahore: Accurate Printers, 1948). In several letters, Nehru actively questioned the right of the All India Muslim League to use the prefix "All India" because of their exclusive membership.

17 Ibid.

18 Jawaharlal Nehru, "The Unity of India," Foreign Affairs 16, no. 2 (January 1938): $230-232$.

19 Ibid., 243.

20 Ibid.

21 Jawaharlal Nehru, The Discovery of India (New Delhi: Penguin, 2004), 51-52; P. Oomman Phillips, "Nehru Survives Challenge, Demands National Unity," Christian Century (November 1, 1950): 1308. 


\section{Introduction: Becoming All India}

22 When the final date of independence was announced, it was also announced that the British had decided to partition the subcontinent into two independent states, Pakistan and India. Pakistan would have two "wings," East Pakistan, which was created out of the Muslim majority provinces of Bengal primarily, (and which would later become Bangladesh), and West Pakistan, which was formed out of the provinces west of the Punjab and parts of the Punjab. Pakistan's independence day was actually a day before Indian independence, on August 14, 1947. Communal violence especially between Hindus and Muslims along the border began in 1946, and escalated through independence and after.

23 There are a large number of books dedicated to the conflict between the All India Muslim League and the Indian National Congress during the early twentieth century. See, for example, Mushirul Hasan, ed., India's Partition: Process, Strategy, and Mobilization (New York: Oxford University Press, 1993); Ayesha Jalal, The Sole Spokesman: Jinnah, the Muslim League, and the Demand for Pakistan (Cambridge: Cambridge University Press, 1994).

24 Barbara D. Metcalf and Thomas R. Metcalf, A Concise History of Modern India (Cambridge: Cambridge University Press, 2006), 225.

25 Ali Parchami, Hegemonic Peace and Empire: The Pax Romana, Britannica, and Americana (Oxon: Routledge, 2009), 94-95. Parchami includes several examples of British claims about Pax Britannica as it pertains to India.

26 Ibid.

27 Maulana Mohammed Ali, "Speech at the Fourth Plenary Session of the Round Table Conference in London, 19th November, 1930," in Pakistan Movement Historical Documents, ed. G. Allana (Karachi: Department of International Relations, University of Karachi, nd. [1969]), 61-75, accessed online at www.columbia.edu/itc/mealac/ pritchett/00islamlinks/txt_muhammadali_1930.html.

28 For example, a December 19, 1940, cartoon in the Hindustan Times depicts the then viceroy, Lord Linlithgow, arms outstretched, each hand holding a noose attached to, on the left, a Hindu man, and on the right, a Muslim man. On his arms is written the words "divide and rule." The caption to the cartoon is a quote from Lord Linlithgow:

We are entitled to claim, we do claim, and I claim today that it is for the Indian parties themselves; for those communities, interests, and political leaders concerned to get together and to see what they can do by way of reaching accommodation with one another.

("The Indian Axis at Work," Hindustan Times, December 19, 1940, 4)

29 R. J. Moore, The Crisis of Indian Unity, 1917-1940 (Oxford: Clarendon Press, 1974).

30 Jayaprakash Narayan, "The Challenge of Democracy," Indian Listener, August 30, 1953 , 3. In later years, Narayan continued to question the way that the Indian state understood their democratic values, and his movement, Total Revolution, was named as the primary reason for the emergency legislation in the 1970s.

31 Narayan, 3.

32 Ibid.

33 Ibid.

34 B. Shiva Rao, "National Programme: The Challenge to Democracy," Indian Listener, June 28, 1953; J. P. Narayan, "National Programme: The Challenge to Democracy," Indian Listener, August 30, 1953; Dr. John Matthai, "National Programme: The Challenge to Democracy," Indian Listener, September 6, 1953.

35 Stanley Wolpert, Tilak and Gokhale: Revolution and Reform in the Making of Modern India (New Delhi: Oxford University Press, 1991), 268.

36 Many organizations included support for democracy in their constitutions, as the All India Women's Conference did when it rewrote their constitution in 1939 (Nehru Memorial Museum and Library, All India Women's Conference Papers, File no. 211).

37 Christophe Jaffrelot, Religion, Caste, and Politics in India (New York: Colombia University Press, 2011), 213. 
38 Sudipta Kaviraj, The Imaginary Institutions of India: Politics and Ideas (New York: Columbia University Press, 2010), 26.

39 Leela Gandhi, The Common Cause: Postcolonial Ethics and the Practice of Democracy, 1900-1955 (Chicago: University of Chicago Press, 2014): 14-15, 20.

40 Faisal Devji, "The Minority as Political Form," 87-88; Barbara Metcalf, "Observant Muslims, Secular Indians: The Political Vision of Maulana Husain Ahmed Madani, 1938-57," in From Colonial to Postcolonial, 106-110; Zoya Hasan, Politics of Inclusion: Castes, Minorities, and Affirmative Action (New Delhi: Oxford University Press, 2009), 18-40; Neera Chandhoke, "Individual and Group Rights: A View from India," in India's Living Constitution: Ideas, Practices, Controversies, ed. Zoya Hasan, E. Sridharan, and S. Sudarshan (London: Anthem Press, 2005), 222; Granville Austin, "The Expected and Unintended in Working a Democratic Constitution," in India's Living Constitution, 322.

41 Rajni Kothari, Rethinking Democracy (London: Zed Books, 2007), 96.

42 "Constituent Assembly of India, Volume 1," Friday 13 December 1946. http:// parliamentofindia.nic.in/ls/debates/vol.1p5.htm, last accessed January 14, 2015.

43 Ibid.

44 Ibid.

45 An Indian Christian, "Minorities Corner," Dawn, January 11, 1946, 10.

46 Ibid.

47 Peter Geschiere, The Perils of Belonging: Autochthony, Citizenship, and Exclusion in Africa \& Europe (Chicago: University of Chicago Press, 2009), 6-7.

48 Farhat Hasan, "Forms of Civility and Publicness in Pre-British India," in Civil Society, Public Sphere and Citizenship: Dialogues and Perceptions, ed. Rajeev Bhargava and Helmut Reifeld (New Delhi: Sage Publications, 2005), 101-105; Satish Saberwal, "Introduction: Civilization, Constitution, Democracy," India's Living Constitution: Ideas, Practices, Controversies, 15.

49 Frank Anthony speech in "Constituent Assembly of India, Volume 11," November 25, 1949 (http://parliamentofindia.nic.in/ls/debates/vol.11p11.htm), last accessed March 12, 2015.

50 Ibid.

51 Srirupa Roy, "A Symbol of Freedom: The Indian Flag and the Transformations of Nationalism, 1906-2002," Journal of Asian Studies 65, no. 3 (August 2006): 496.

52 Roy, Beyond Belief, 157-158.

53 Ornit Shani, "Conceptions of Citizenship in India and the 'Muslim Question,'” Modern Asian Studies 44, no. 1 (2010): 146.

54 Sunil Khilnani, The Idea of India (New York: Farrar, Straus and Giroux, 1998), $27-28$.

55 Gyandendra Pandey, "Introduction," in Subalternity and Difference: Investigations from the North and the South (Oxon: Routledge, 2011), 4.

56 The Dawn (December 15, 1946), 7.

57 Pandey, 6.

58 Barbara Metcalf, "Observant Muslims, Secular Indians: The Political Vision of Maulana Husain Ahmad Madani, 1938-57," in From the Colonial to the Postcolonial: India and Pakistan in Transition, ed. Dipesh Chakrabarty, Rochona Majumdar, and Andrew Sartori (New Delhi: Oxford University Press, 2007), 96-118.

59 This section is revised and reprinted in Emily Rook-Koepsel, "Ghosts of Indian Unity: Difference, Diversity, and Violence," Kairos: A Journal of Critical Symposium 2, no. 1 (2017): 69-71.

60 Gyandendra Pandey, Remembering Partition, 154.

61 Ethiopia's current state slogan is "Diversity in Unity," for example. For more on this, see Lahra Smith, Making Citizens in Africa: Ethnicity, Gender, and National Identity in Ethiopia (Cambridge: Cambridge University Press, 2013). Thanks to Daniel Mains for drawing my attention to this point. 
62 Madhava Prasad writes interestingly about the idea of commitment that allows a person to hold one position and think critically about it at the same time. Madhava Prasad, "On the Question of a Theory of (Third) World Literature," in Dangerous Liaisons: Gender, Nation, and Postcolonial Perspectives, ed. Anne McClintock, Aamir Mufti, and Ella Shohat (Minneapolis: University of Minnesota Press, 1997), 158.

63 John Beverley, "Theses on Subalternity, Representation, and Politics," Postcolonial Studies 1, no. 3 (1999): 308.

64 Amartya Sen, "The Politics of History," in Pluralism and Democracy in India: Debating the Hindu Right, ed. Wendy Doniger and Martha C. Nussbaum (New York: Oxford University Press, 2015), 26; Ramachandra Guha, "Arguments with Sen," Economic and Political Weekly 40 (October 8-14, 2005): 4420-4425.

65 In one of the group's most famous essays, Ranajit Guha pushed scholars to listen to the "small" voice of history by paying attention to the ways that nationalist history leaves out subaltern voices. Ranajit Guha, "The Small Voice of History," in Subaltern Studies 9: Writings on South Asian History and Society, ed. Shahid Amin and Dipesh Chakrabarty (New Delhi: Oxford University Press, 1996), 1-12. Also in this volume, see Kamala Visweswaran, "Small Speeches, Subaltern Gender: Nationalist Ideology and its Historiography," in Subaltern Studies 9, ed. Amin and Chakrabarty, 83-125. Guha followed this discussion of the need for an expansive history with another more rousing call for it in his book History at the Limit of World-History (New York: Columbia University Press, 2003). Other authors in the group, notably Shahid Amin, Event, Memory, Metaphor: Chauri Chaura, 1922-1992 (New Delhi: Oxford University Press, 1995); and Gyanendra Pandey, Remembering Partition: Violence, Nationalism and History in India (Cambridge: Cambridge University Press, 2001), have put pressure on nationalist constructions of the nation and its pivotal movements. There have been many other discussions of history's statist past, especially as it acted as a cover for colonial domination and later as a ploy of nationalism. One need only read Hegel's Introduction to the Philosophy of History, with its global historical explanation for European colonial domination, to understand the power of history as a tool for defining the state as ideal. G. W. F. Hegel, Introduction to the Philosophy of History, trans. Leo Rauch (Indianapolis: Hackett Publishing Company, 1988). Mahua Sarkar, "Difference in Memory," Comparative Studies in Society and History 48, no. 1 (2006): 140-141; Durba Ghosh, "National Narratives and the Politics of Miscegenation: Britain and India," in Archive Stories: Facts, Fictions, and the Writing of History, ed. Antoinette Burton (Durham, NC: Duke University Press, 2005), 28-29. The English should not have been surprised when their colonial subjects used the British history trick on the British themselves. For more on this subject, see Richard Roberts, "History and Memory: The Power of Statist Narratives," International Journal of African Historical Studies 33, no. 3 (2000): 513-522.

66 R. R. Diwakar, "Forward," in An Anthology of Indian Literatures, ed. K. Santhanam (Bombay: Bharatiya Vidya Bhavan, 1969); Indian Literatures of Today, ed. Bharatan Kumarappa (Bombay: All India PEN Centre, 1947); Indian Writers in Council Proceedings of the First All-India Writers' Conference, Jaipur 1945, ed. K. R. Srinivasa Iyengar (Bombay: International Bookhouse Ltd., 1945); Aspects of Indian Music: A Series of Special Articles and Papers Read at the Music Symposia Arranged by All India Radio (New Delhi: Ministry of Information and Broadcasting, 1957); Kamaladevi Chattopadhey, Toward a National Theatre (Aundh: Aundh Publishing Trust, 1945).

67 Renuka Ray, "The All India Conference as a National Forum," All India Women's Conference Souvenir: 1927-1970 (New Delhi: All India Women's Conference, 1971).

68 Jawaharlal Nehru, "Tryst with Destiny," on Voices of Freedom: The Spirit of Freedom and Progress Speaks through Our Leaders, disc 1 track 2, Saregama Recordings (2009). 
69 Jyotsna G. Singh, Colonial Narratives/Cultural Dialogues: "Discoveries" of India in the Language of Colonialism (London: Routledge, 1996), 155-157; Nizar Ahmed, "A Note on Gandhi, Nation and Modernity," Social Scientist 34, no. 5/6 (May-June 2000): 50-69.

70 Jancy James, "Literary Research as National Integration: A Tribute to K. M. George," Indian Literature 48, no. 2 (2004): 140.

71 Humayun Kabir, The Indian Heritage (Bombay: Asia Publishing House, 1955).

72 B. R. Ambedkar, Pakistan or the Partition of India (Bombay: Thacker, 1946), 11-21. Ambedkar was explicitly analyzing India's claims to national coherence on the basis of Ernest Renan's essay, "What is a Nation." Ernest Renan, "What is a Nation," trans. Martin Thom, in Nation and Narration, ed. Homi Bhabha (Oxon: Routledge, 1990), 8-22.

73 Ambedkar, Pakistan, 11-21.

74 Interestingly, while Congress complained vigorously about separate electorates and the harm they did to unity in India, they were careful not to criticize all of the British colonial states' divisive practices. Most glaringly, however, the party was careful not to rail against the enactment of religion-specific personal laws, at least in fair measure because they were popular with their right-leaning Hindu constituency. Bernard S. Cohn, Colonialism and Its Forms of Knowledge: The British in India (Princeton, NJ: Princeton University Press, 1996); Bernard S. Cohn, "Notes on the History of the Study of Indian Society and Culture," in An Anthropologist Among the Historians and Other Essays (New Delhi: Oxford University Press, 2001), 136-171; Ranajit Guha, A Rule of Property for Bengal: An Essay on the Idea of Permanent Settlement (Durham, NC: Duke University Press, 1996).

75 "Dr. Khan Saheb on the Unity of India," Modern Review 75, no. 2 (1944): 95. For an interesting look at the idea of divide and rule in the African colonial context, see Patricia Lorcin, "Imperialism, Colonial Identity, and Race in Algeria, 1830-1870: The Role of the French Medical Corp," Isis 90, no. 4 (December 1999): 653-679.

76 James Scott, Seeing like a State: How Certain Schemes to Improve the Human Condition have Failed (New Haven: Yale University Press, 1999); Etienne Balibar and Immanuel Wallerstein, Race, Nation, Class: Ambiguous Identities (London: Verso, 1991); Joan Scott, Gender and the Politics of History (New York: Columbia University Press, 1999).

77 Gyandendra Pandey makes an excellent argument against the use of the word "Hindutva," literally translated as "Hindu-ness," as an equivalent to Hindu Nationalism both because it adopts Hindu nationalists' self-definition into arguments critiquing their ideology, and because it allows Hindu Nationalists' idea of Hindu-ness to define Hindu-ness more generally. Gyandendra Pandey, "Monumental History," in Routine Violence: Nations, Fragments, and History (Stanford: Stanford University Press, 2006), 89.

78 Dilip Menon, "An Inner Violence: Why Communalism in India is about Caste," in The Future of Secularism, ed. T. N. Srinivasan (New Delhi: Oxford University Press, 2009).

79 Publications continued to come out defending and affirming the fundamental unity of India even long after independence. One example is Facets of Indian Unity (New Delhi: Ministry of Information and Broadcasting, 1965).

80 "Speech handed in by Dr. Ambedkar," Dr. B. R. Ambedkar Papers, AccNo 478, National Archives of India (NAI). When a speech is "handed in," it means that the speech is entered into the records of the meeting as written.

81 Ibid., 21.

82 Ibid. On democracy and "the masses," see Upendra Baxi, "Indian Democracy: A Critique," in Challenges to Democracy in India, ed. Rajesh Basrur (New Delhi: Oxford University Press, 2009), 56-57.

83 Ibid., 23. 


\section{Introduction: Becoming All India}

84 B. R. Ambedkar, Speech on the Ratification of the Constitution, "Constituent Assembly of India, Volume 11," November 25, 1949, http://parliamentofindia.nic.in/ 1s/debates/vol.11p11.htm, last accessed March 12, 2015.

85 It is worth pointing out, as Christine Keating does, that universal suffrage as a settled promise of Indian independence did entail activism. Moreover, the claim that it was an untaught impulse by the Congress disregards the kind of labor that was necessary to advocate for marginal populations as citizens of a potential independent India. Women's activist organizations petitioned both the colonial government of India and Indian political parties to gain votes for women, and later to remove franchise rules about marital status and land tenure. Similarly, activists for greater inclusion of lowercaste and lower-class populations in the franchise fought to make universal suffrage seem reasonable. It is still the case that people implicitly critique and/or praise Indian democracy for its willingness to include such a large population of poor and illiterate citizens in the franchise. See Christine Keating, Decolonizing Democracy: Transforming the Social Contract in India (University Park, PA: Pennsylvania State University Press, 2011), 44-50; on continued disbelief/praise of Indian poverty franchise, see "What's Gone Wrong with Democracy?," The Economist (March 1-7, 2014): 48.

86 Chantel Mouffe, The Democratic Paradox (London: Verso, 2005), 2-3, 5; Neera Chandhoke, "Participation, Representation, and Democracy in Contemporary India," American Behavioral Scientist 52, no. 6 (February 2009): 814.

87 Pratap Bhanu Mehta, "The State of Indian Democracy," in Challenges to Democracy (New Delhi: Oxford University Press, 2009), 49.

88 Zoya Hasan, "Indian Democracy and Inequalities," in Challenges to Democracy (New Delhi: Oxford University Press, 2009), 128.

89 Keating, Decolonizing Democracy, 59-60.

90 Ibid., 70.

91 Ibid., 63.

92 "Fundamental Unfreedoms: A Note on the Situation of Adivasis in Bastar," India Resists, January 5, 2015. www.indiaresists.com/fundamental-unfreedoms-a-note-onthe-situation-of-adivasis-in-bastar/, last accessed March 12, 2015.

93 Sudipta Kaviraj, The Imaginary Institutions of India: Politics and Ideas (New York: Columbia University Press, 2010), 13-15.

94 Ibid.; Sunil Khilnani, The Idea of India (New York: Farrar, Straus and Giroux, 1999), 21,30 .

95 For some rhetoric along these lines, see Vallabhbhai Patel's speech on the question of minority rights in the constitution during the Constituent Assembly. "Constituent Assembly Vol. 5," Thursday August 28, 1947, http://parliamentofindia.nic.in/ls/ debates/vol.5p9a.htm. 
mean anti-national politics. ${ }^{78}$ Yet for the All India Scheduled Castes Federation, dissent against the majority and participation in democratic politics on their own terms were taken both as a firm commitment to the nation and as an attempt to define Indian unity with an emphasis on the Indian nation (of which they were resolutely a part) and not on the Indian state (from which they were consistently kept out). Indeed, the idea of creating a minority-majority, emphasizing relationships with other class and caste minorities, as well as seeking relationships with political parties that were aligned with the All India Scheduled Castes Federation's principles, was an attempt to engage a federated minority, if not to establish a presence for the entirety of India's citizenry within the democratic process of the Indian nation. For the All India Scheduled Castes Federation, political unity defined by a vocal majority and silenced minorities was not so much unity as exclusion.

\section{Notes}

1 I would like to explain my choice of the term "Dalit" to define the constituency of the All India Scheduled Castes Federation in this book. By using "Dalit," I hope to consciously recognize what Anupama Rao argues in her excellent history of Dalit politics in India as the "Untouchable" subject's continued struggle to "become Dalit" (emphasis in the original). While the term "Dalit" is anachronistic to the time, it reflects the struggle, violence, and ultimately the insistence of the politics of the All India Scheduled Castes Federation and its advocates and members. Additionally, it is important to make a distinction, as the All India Scheduled Castes Federation did, between the political minority, defined by the bureaucratic term "Scheduled Castes," and the community building and advocacy work done by the self-referential term "Dalit." Although other names were commonly used to describe the community at the time, including Depressed Classes, Very Backward Classes, and Untouchable, I agree with Rao that Dalit offered a name that was organized as a category of self-definition, and used broadly around the country to indicate self-determined advocacy and community building. I am similarly using an uppercase "D" for the Dalit population for, as Rao (xxi) so effectively articulates, "165 million Indians are entitled to a capital letter." Kathleen O'Reilly has noted that in areas where she has seen more extreme forms of internalized caste-ism among Dalits, the term "Dalit" is not used. She hypothesizes that the lack of the advocacybased politics and community inherent in the use of the term "Dalit" is one indicator in the willingness of local Dalit communities to protest caste-based discrimination. In a current political climate where the Indian central government has advised press and media to not use the term "Dalit," instead substituting the more governmental Scheduled Castes, it does feel important to recognize and emphasize the most commonly and preferentially used term of the Dalit political community at large by continuing to use the term here. Anupama Rao, The Caste Question: Dalits and the Politics of Modern India (Berkeley: University of California Press, 2009), xi-xiv; Kathleen O'Reilly, "Toilet Insecurity: Urban Women's Everyday Experience of Inadequate Sanitation in India" (paper presented at Security Challenges in a Turbulent World: International Security Studies Symposium, Norman, Oklahoma, February 25-26, 2015); Jeya Rani, "So the Term 'Dalit' Can't Be Used but 'Brahmin' and 6000 Other Caste Names Can," The Wire, September 14, 2018, https://thewire.in/caste/dalit-brahmin-caste-names.

2 Rao Bahadur N. Sivaraj, "Presidential Address," in Report of the Proceedings of the Third Session of the All India Depressed Classes Conference, Nagpur, July 18 and 19 1942, ed. G. T. Meshram (Nagpur: All India Depressed Classes Association, 1942), $22-23$. 
3 Kunal Debnath, “Ambedkar's Ideas of Nation Building in India," Studies in People's History 5, no. 1 (2018): 104-110.

4 Gail Omvedt, Dalits and the Democratic Revolution: Dr. Ambedkar and the Dalit Movement in Colonial India (New Delhi: Sage Publications, 2014).

5 "Debate on Resolution V: Establishment of All India Scheduled Castes Federation," in Report of the Proceedings of the Third Session of the All India Depressed Classes Conference, 43.

6 G. T. Meshram, "Forward," in Report of the Proceedings of the Third Session of the All India Depressed Classes Conference, 1.

7 Dr. B. R. Ambedkar, "Keynote Address," in Report of the Proceedings of the Third Session of the All India Depressed Classes Conference, 35.

8 "Resolutions," in Report of the Proceedings of the Third Session of the All India Depressed Classes Conference, 5.

9 Luis Cabrera, “Gandhiji I Have No Homeland': Cosmopolitan Insights from BR Ambedkar, India's Anti-Caste Campaigner and Constitutional Architect," Political Studies 65, no. 3 (October 2017): 576-593.

10 Anupama Rao, "Ambedkar and the Politics of Minority: A Reading," in From the Colonial to the Postcolonial: India and Pakistan in Transition (New Delhi: Oxford University Press, 2007), 149-152.

11 Gopal Guru, "They Always Speak with their Eyes Cast Down: Dalits on the Margin of Indian Democracy," Social Text, February 27, 2015, accessed March 10, 2015, http://socialtextjournal.org/periscope_article/they-always-speak-with-their-eyes-castdown-dalits-on-the-margin-of-indian-democracy/\#sthash.UfWTS4Q6.58hlz8K7.dpuf.

12 Ajay Skaria, “'Can the Dalit Articulate a Universal Position?': The Intellectual, the Social, and the Writing of History," Social History 39, no. 3 (2014): 343.

13 Christophe Jaffrelot, Dr. Ambedkar and Untouchability: Fighting the Indian Caste System (New York: Columbia University Press, 2005), 5. In their book Dalit Liberation Movement in the Colonial Period, Gail Omvedt and Bharat Patankar argue that there are several differences between the set of people whom they properly call Dalit, and those who were indicated in the Scheduled Castes. Patankar and Omvedt point out that the Scheduled Castes "includes lower-level, semi-tribal groups, who were not dalits as defined here." Bharat Patankar and Gail Omvedt, The Dalit Liberation Movement in the Colonial Period (New Delhi: Critical Quest, 2004), 7.

14 Dilip M. Menon, The Blindness of Insight: Essays on Caste in Modern India (Chennai: Navayana, 2006), 10.

15 On the other often-used name for Dalits, "Harijan," G. T. Meshram stated that "no useful purpose is served by calling our community by that hated name of 'Harijan." "' He argued that the use of the name "Harijan" for the community merely let Congress and Caste Hindus in general off the hook for their poor treatment of Dalits, and allowed them to pass over the need for "amends." G. T. Meshram, "Reception Committee Address," Report of the Proceedings of the Third Session of the All India Depressed Classes Conference, 14.

16 Gopal Guru and Anuradha Chakravarty, "Who are the Country's Poor?: Social Movement Politics and Dalit Poverty," in Social Movements in India: Poverty, Power, and Politics, ed. Raka Ray and Mary Fainsod Katzenstein (Lanham, MD: Rowman and Littlefield Publishing, 2005), 139.

17 Gopal Guru, "Experience, Space, and Justice," in The Cracked Mirror: An Indian Debate on Experience and Theory, ed. Gopal Guru and Sundar Sarukkai (New Delhi: Oxford University Press, 2012), 106; Sankaran Krishna, "On Introducing Ambedkar," Economic and Political Weekly 49, no. 16 (April 19, 2014): 24.

18 Dennis Dalton, "Introduction to Writings about Untouchability," in Mahatma Gandhi: Selected Political Writings, ed. Dennis Dalton (Indianapolis: Hackett Publishing Company, 1996), 117; Mohandas K. Gandhi, "Speech at Public Meeting, Trinchinopoly," in Mahatma Gandhi: Selected Political Writings, ed. Dennis Dalton, 122-124. 
On the feeling about the name "Harijan" at the All India Depressed Classes Conference, see G. T. Meshram, 14.

19 This is as opposed to the Congress-affiliated social uplift organization, the Harijan Sevak Sangh (or Harijan Service Society), which focused on Caste Hindu "service" to their "Harijan" brothers, a formulation that was both demeaning and undermining to Dalit arguments about their status as a political minority and separate social element in India.

20 B. R. Ambedkar, Annihilation of Caste, in The Essential Writings of B. R. Ambedkar, ed. Valerian Rodrigues (New Delhi: Oxford University Press, 2002), 263, emphasis in the original.

21 B. R. Ambedkar, "Caste in India," in Caste and Democratic Politics in India, ed. Ghanshyam Shah (London: Anthem Press, 2002), 66.

22 R. R. Bhole, "An Untouchable Speaks," Bhole Papers, Speeches and Writings by him S. no. 4, Nehru Memorial Museum and Library (NMML), Private Papers Archives.

23 B. R. Ambedkar, Memorandum on Linguistic States, B. R. Ambedkar Papers, NMML, reel 4.

24 Sundar Sarukkai, "Phenomenology of Untouchability," in The Cracked Mirror: An Indian Debate on Experience and Theory, ed. Gopal Guru and Sundar Sarukkai (New Delhi: Oxford University Press, 2012), 184-187.

25 Ibid., 199

26 V. Geetha, "Bereft of Being: The Humiliations of Untouchability," in Humiliation: Claims and Context, ed. Gopal Guru (New Delhi: Oxford University Press, 2009), 96.

27 Sanjay Palshikar, "Understanding Humiliation," in Humiliation: Claims and Context, ed. Gopal Guru (New Delhi: Oxford University Press, 2009), 87-88. It is worth saying that the term "Dalit," which means, "ground down," could have similar valences. "Untouchable" offers no remediation or expectation of the need of remediation, it is simply taint, whereas "ground-down" references the importance of the structural conditions of domination by moving the taint of the inequality from the discriminated against to the aggressor. Upendra Baxi, "Emancipation as Justice: Legacy and Vision of Dr. Ambedkar," in From Periphery to Centre Stage: Ambedkar, Ambedkarism, and Dalit Future, ed. K. C. Yadav (New Delhi: Manohar Books, 2000), 68.

28 Anupama Rao, The Caste Question, 270-272.

29 Report of the Proceedings of the Third Session of the All India Depressed Classes Conference, 5.

30 B. K. Gaikwad, "Introduction of the Resolutions of the Third Session of the All India Depressed Classes Conference," in Report of the Proceedings of the Third Session of the All India Depressed Classes Conference, 40.

31 On the forced labor system, see Ranajit Guha, Dominance without Hegemony: History and Power in Colonial India (Cambridge, MA: Harvard University Press, 1998), 26-31; J. Mohan Rao, "Agrarian Power and Unfree Labour," Journal of Peasant Studies 26, no. 2-3 (1999): 242-262.

32 Jaffrelot, 81-82. He points out that the move for Dalit villages was similar and possibly influenced by the Periyar claim for Dravidasthan.

33 Eleanor Zelliot, Dr. Babasaheb Ambedkar and the Untouchable Movement (New Delhi: Blumoon Books, 2004), 194-195.

34 Gail Omvedt, "Ambedkar vs. Gandhi: A Part that Parted," Outlook Magazine, August 20, 2012, www.outlookindia.com/article/a-part-that-parted/281929; B. R. Ambedkar, States and Minorities: What are Their Rights and How to Secure Them in the Constitution of Free India (Memorandum on the Safeguards for the Scheduled Castes submitted to the Constituent Assembly on behalf of the All India Scheduled Castes Federation) (Bombay: Thacker, 1947), Article II, Clause IV, part 2; B. R. Ambedkar, "Outside the Fold," in The Essential Writings of B. R. Ambedkar, ed. Valerian Rodrigues, 323-331; All India Scheduled Castes Federation Standing Committee, 
Election Manifesto of the Scheduled Castes Federation, 1952, 4-8, Ambedkar Papers, NMML.

35 Shabnum Tejani, "The Necessary Conditions of Democracy: B. R. Ambedkar on Nationalism, Minorities, and Pakistan," Economic and Political Weekly 48, no. 50 (December 14, 2013): 116.

36 Gopal Guru, "Understanding Ambedkar's Construction of the National Movement," Economic and Political Weekly 33, no. 4 (January 30, 1998): 157.

37 V. N. Barve, "A Note on the Harijan Problem in Maharashtra, 1941," page 43 in Ambedkar Papers, NMML.

38 Rao, The Caste Question, 157-160; M. S. Gore, The Social Context of an Ideology: Ambedkar's Social and Political Thought (New Delhi: Sage Publications, 1993), 140.

39 Barve, 44.

40 Gyanendra Pandey, "Citizenship and Difference: The Muslim Question in India," in The Unfinished Agenda: Nation-Building in South Asia, ed. Mushirul Hasan and Nariaki Nakazato (New Delhi: Manohar Books, 2001), 115-116.

41 Jawaharlal Nehru, An Autobiography (New Delhi: Jawaharlal Nehru Memorial Fund, 2002), 552.

42 C. Rajagopalachari, Ambedkar Refuted (Bombay: Hind Kitab, 1946), 20-22, 31-33.

43 Partha Chatterjee, Nationalist Thought and the Colonial World: A Derivative Discourse (Tokyo: The United Nations University, 1986), 51.

44 G. M. Thaware, "Salvation of the Depressed Classes Lies in Joint Electorates," Hitavada Press, Nagpur, March 31, 1932, Ambedkar Papers, NMML.

45 Sehkar Bandyopadhyay, "Transfer of Power and the Crisis of Dalit Politics in India, 1945-47," Modern Asian Studies 34, no. 4 (2000): 940.

46 Francesca R. Jensenius, "Mired in Reservations: The Path-Dependent History of Electoral Quotas in India," Journal of Asian Studies 74, no. 1 (February 2015): 100.

47 Aamir Mufti, Enlightenment in the Colony: The Jewish Question and the Crisis of Postcolonial Culture (Princeton, NJ: Princeton University Press, 2007), 13.

48 Nicholas Dirks, Castes of Mind: Colonialism and the Making of Modern India (Princeton, NJ: Princeton University Press, 2001), 13.

49 Based on context, the speech, though undated, must have been given after Ambedkar left the government in 1951 but before the 1952 elections. File no. 3 Ambedkar papers, NMML.

50 Ibid.

51 B. R. Ambedkar, "Castes in India," 63.

52 Rao, The Caste Question, 24-27; Zoya Hasan, Politics of Inclusion: Castes, Minorities, and Affirmative Action (New Delhi: Oxford University Press, 2009), 26.

53 Even among the Jats encompassed by the Scheduled Castes, people claim a hierarchy based on occupation and caste name. Additionally, clear caste hierarchy has in recent years become somewhat blurred as activists of some Other Backward Castes have posited that they are under significantly harder caste-based disability because they have been less well organized. See Assa Doron, "Caste Away? Subaltern Engagement with the Modern Indian State," Modern Asian Studies 44, no. 4 (2009): 753-783; Sumit Chaturvedi "Caste Publications: The Space for Upper Caste Subculture Politics," Economic and Political Weekly 49, no. 17 (April 26, 2014): 33-37.

54 Even the most sensitive of scholars occasionally call the party the "All India Scheduled Caste Federation," which flattens the party's politics significantly.

55 "Address by Dr. B. R. Ambedkar," in Report of the Proceedings of the Third Session of the All India Depressed Classes Conference, 35.

56 Letter from Kamalakant Chitre to B. R. Ambedkar, January 14, 1952, in B. R. Ambedkar Papers, AccNo 434, National Archives of India (NAI), New Delhi.

57 Jaffrelot 81-86.

58 Gore, 174-175; Bandyopadhyay, 941-942; Gail Omvedt, Dalit Visions: The AntiCaste Movement and the Construction of an Indian Identity (New Delhi: Orient Longman, 2006), 50-51. 
59 Pavan Dahat, "JNU Scholars to Revive Dr. Ambedkar's Political School," The Hindu, July 2, 2016.

60 Letter from B. R. Ambedkar to Kamalakant Chitre January 18, 1952, Ambedkar papers, NAI.

61 Correspondence B. R. Ambedkar and Jawaharlal Nehru December 1947, Ambedkar Papers, NMML.

62 B. R. Ambedkar "Grievances of the Scheduled Castes: Memorandum Submitted to His Excellency the Governor-General on 29th October, 1942," Ambedkar Papers, NMML; Ambedkar, States and Minorities, Article II, Section II, Clause IV.

63 "Resolution V: Establishment of the All India Scheduled Castes Federation," Report of the Proceedings of the Third Session of the All India Depressed Classes Conference, 5.

64 On why national politics is primarily middle-class politics, see Patrick Barr-Melej, Reforming Chile: Cultural Politics, Nationalism, and the Rise of the Middle Class (Chapel Hill, NC: University of North Carolina Press, 2001), 1-18; Leela Fernandes, "Nationalizing 'the Global': Media Images, Cultural Politics, and the Middle Class in India," Media Culture Society 22, no. 5 (September 2000): 611-628. On the Dalit movement, Guru Gopal, "Misrepresenting the Dalit Movement," in Untouchable: Dalits in Modern India, ed. S. M. Michael (Boulder, CO: Lynne Rienner Publishers, 1999), 97.

65 Correspondence, B. K. Gaikwad to B. R. Ambedkar, 10/2/1945, Ambedkar Papers, NMML.

66 Ibid.

67 Ibid.

68 Ibid., and B. R. Ambedkar, "From Millions to Fractions," in The Essential Writings of B. R. Ambedkar, ed. Valerian Rodrigues (New Delhi: Oxford University Press, 2002), 350 .

69 B. R. Ambedkar, "Ranade, Gandhi, and Jinnah," in The Essential Writings of B. R. Ambedkar, ed. Valerian Rodrigues (New Delhi: Oxford University Press, 2002), 123.

70 All India Scheduled Castes Federation Standing Committee, Election Manifesto of the Scheduled Castes Federation, 1952, 14-15, Ambedkar Papers, NMML.

71 B. R. Ambedkar, Pakistan or the Partition of India (Bombay: Thacker, 1946), 11-21.

72 Broadcast talk from the Bombay Radio Station 9, November 1942, Dr. B. R. Ambedkar entitled "Why Indian Labour is Determined to Win this War," in the R. R. Bhole Files Printed Materials S., no. 5, Nehru Memorial Museum and Library (NMML), 7.

73 R. R. Bhole, "An Untouchable Speaks," Bhole Papers, NMML; Rajagopalachari, 6-7.

74 Ambedkar, "Why Indian Labour ..." NMML, 7.

75 R. R. Bhole, "An Untouchable Speaks," 9-10; Baxi, 72-73.

76 Ambedkar, "To the Princes and People of India: Funds for a Social Centre for the Untouchables in Bombay, The scheme needs Rs.325,000, Won't You Help? An Appeal," Ambedkar Papers, NMML.

77 Hyderabad Scheduled Castes Federation Speech, September 20, 1944, Ambedkar Papers, NMML. The speech is not reproduced in its entirety (as some of the other speeches from this event were), yet perhaps the report of the speech for the newsletter is just as important in thinking about a wider party understanding.

78 B. R. Ambedkar, "Caste, Class, and Democracy," in The Essential Writings of B. R. Ambedkar, ed. Valerian Rodrigues, 132-148. 
in his 1949 speech on the ratification of the constitution. Moreover, the façade of equality on the basis of similar treatment meant that many of the programs meant to benefit the constituency were underused. For example, there were quotas enacted for people from Scheduled Castes in government jobs, and a requirement that Scheduled Castes people be appointed at all levels; however, there were also restrictions on age and education at appointment for many of these positions, and if the successful candidate for the job was required to be a college graduate and younger than 28 years old at appointment, Scheduled Castes people were by and large ineligible to apply, because economic circumstances made it difficult for them to have consistent enough schooling to complete a bachelor's degree by age 28. As such, positions remained unfilled or, after searching in vain for an acceptable candidate from the Scheduled Castes, were filled with an upper-caste person. Despondently looking at these failures of democratic promise, Ambedkar urged that the only way to fully claim Dalit political rights, and fight for further social and economic democracy, was to push for a united front..$^{90}$

The frustration at the continuation of the denial of respect, responsibility, and politics of the Dalit constituency as a legitimate minority pushed Dalit leaders to form the All India Scheduled Castes Federation as a way to channel negative affect into action to rearticulate democratic values in India. Focusing on their party as a principled political body formed to advocate for the constituencies of the Scheduled Castes, the All India Scheduled Castes Federation emphasized the need for a democratic state that would be flexible enough to understand how true political equality was linked to social and economic change. Eschewing the simple dichotomy between need-based politics and minority, the leaders of the All India Scheduled Castes Federation contended that a negotiated political space where majority populations listened to minority voices and respected principled stands would benefit society as a whole and make for a more robust, strongly effective democracy.

While the party was largely unsuccessful electorally, the push to create a space for Dalit political action, and the critiques of simple political equality, continue to resonate. Dalit politicians and activists continue to place a high priority on channeling feelings of frustration and anger into political action and to call for a more clearly articulated social and economic democracy. ${ }^{91}$ Understanding the critiques of majority politics embedded in All India Scheduled Castes Federation writings about voice, principle, and communal politicssimilar to the critique of democracy posited by women's political activistsmeant mounting a thoroughgoing critique of the politics of universal citizenship.

\section{Notes}

1 Letter from Kamalakant Chitre to B. R. Ambedkar January 14, 1952, in B. R. Ambedkar Papers, NAI.

2 Dwaipayan Sen, The Decline of the Caste Question: Jogendranath Mandal and the Defeat of Dalit Politics in Bengal (Cambridge: Cambridge University Press, 2018).

3 Gail Omvedt, Ambedkar: Towards an Enlightened India (New Delhi: Viking Penguin Books, 2004), 103-106. 
4 Anupama Rao, The Caste Question: Dalits and the Politics of Modern India (Berkeley: University of California Press, 2009), 157-159; Ayesha Jalal, "Exploding Communalism: The Politics of Muslim Identity in India," in Nationalism, Democracy and Development: State and Politics in India, ed. Sugata Bose and Ayesha Jalal (New Delhi: Oxford University Press, 1999), 76-103; Gail Omvedt, Dalit Visions: The AntiCaste Movement and the Construction of an Indian Identity (New Delhi: Orient Longman, 2006), vii.

5 Anupama Roy, Mapping Citizenship in India (New Delhi: Oxford University Press, 2010), 174-175.

6 B. R. Ambedkar "Speech Handed in at the Round Table Conference" Ambedkar Papers, AccNo 434, National Archives of India (NAI), New Delhi.

7 Ibid., 21

8 Ibid., 23.

9 Neera Chandhoke, "Individual and Group Rights: A View from India," in India's Living Constitution: Ideas, Practices, Controversies, ed. Zoya Hasan, E. Sridharan, and S. Sudarshan (London: Anthem Press, 2005), 207-241.

10 Muhammad Iqbal, "Presidential Address, 1930," in Speeches, Writings, and Statements of Iqbal, ed. Latif Ahmed Sherwani (Lahore: Iqbal Academy, 1977), 3-26.

11 Gyan Prakash, "Secular Nationalism, Hindutva, and the Minority," in The Crisis of Secularims in India, ed. Anuradha Dingwaney Needham and Rajeswari Sunder Rajan (Durham, NC: Duke University Press, 2007), 183.

12 Lisa Mitchell, Language, Emotion, and Politics in South India: The Making of a Mother Tongue (Bloomington, IN: Indiana University Press, 2009).

13 Indeed, in Gandhi's observances on the book Ashram Observances, he argues that although "politics are part of our being," he limits knowledge and participation in politics to "our national institutions" and "our national growth," emphasizing that it is mostly appropriate for students and structurally minded adults but separate from the social uplift struggles. M. K. Gandhi, Ashram Observances in Action, trans. Valji Govindji Desai (Ahmedabad: Navajivan Publishing House, 1998), $87-88$.

14 M. K. Gandhi, From Yeravda Mandir: Ashram Observances, trans. Valji Govindji Desai (Ahmedabad: Navajivan Publishing House, 2005), 20.

15 James Massey, "Minority Rights in the South Asian Countries with Special Reference to India," in Reflections on Dalit and Minorities Issues: An Anthology, ed. Mohd. Mujtaba Khan (New Delhi: Dr. K. R. Narayanan Centre for Dalit and Minorities Studies, Jamia Millia Islamia, and Kanishka Publishers, 2007), 19, 37; Romila Thapur, "Communalism and the Historical Legacy: Some Facets," Social Scientist 18, no. 6/7 (June-July 1990): 18; Ashutosh Varshney, "Contested Meanings: India's National Identity, Hindu Nationalism, and the Politics of Anxiety," Daedalus 122, no. 3 (Summer 1993): 228.

16 All India Scheduled Castes Federation Standing Committee, Election Manifesto of the Scheduled Castes Federation, 1952, especially section entitled "A Problem of Raising the Backward Classes," 4, Ambedkar Papers, NMML.

17 Immanuel Wallerstein, "The Construction of Peoplehood: Racism, Nationalism, Ethnicity," in Race, Nation, Class: Ambiguous Identities, ed. Immanuel Wallerstein and Etienne Balibar (London: Verso, 1991), 71-85; Saad Eddin Ibrahim, Egypt, Islam, and Democracy (Cairo: American University in Cario Press, 2002); Nikhil Pal Singh, Black is a Country: Race and the Unfinished Struggle for Democracy (Cambridge, MA: Harvard University Press, 2004).

18 B. R. Ambedkar, Speech on the Ratification of the Constitution, "Constituent Assembly of India, Volume 11," November 25, 1949, http://parliamentofindia.nic.in/ 1s/debates/vol.11p11.htm, last accessed March 12, 2015.

19 J. H. Subbiah, "A Square Deal" speech, September 20, 1944, in Ambedkar Papers, NMML. 
20 See Chapter 2 in this book for a longer discussion of naming and the term "Dalit." Christophe Jaffrelot points out that the Marathi name of the All India Scheduled Castes Federation was the Dalit Federal Party, so it carried some currency locally. I will continue to call the community represented by the All India Scheduled Castes Federation Dalits per the broadly held preference of Dalit activists today. Christophe Jaffrelot, Dr. Ambedkar and Untouchability: Fighting the Indian Caste System (New York: Columbia University Press, 2005), 80; Rosalind O'Hanlon, Caste, Conflict and Ideology: Mahatma Jotirao Phule and Low Caste Protest in Nineteenth Century Western India (Cambridge, Cambridge University Press, 2002); Ramachandra Guha, "The Agrarian Radical: Jotirao Phule," in Makers of Modern India, ed. Ramachandra Guha (Cambridge, MA: Belknap Press, 2011), 71-74.

21 Ambedkar, Speech responding to Shastri, September 24, 1944, Ambedkar Papers, NMML.

22 Faisal Fatehali Devji, "Hindu/Muslim/Indian," Public Culture 5, no. 1 (1992): 3-4; Sekhar Bandyopadhyay "Transfer of Power and the Crisis of Dalit Politics in India," Modern Asian Studies, 34, no. 4 (2000): 895-896.

23 S. Anand, "Resurrecting the Radical Ambedkar" Indian Seminar 601 (September 2009), www.india-seminar.com/2009/601/601_s_anand.htm.

24 Prathama Banerjee, "Thinking Equality: Debates in Bengal, 1870-1940," in Subalternity and Difference: Investigations from the North and the South, ed. Gyanendra Pandey (Oxon: Routledge, 2011), 143.

25 The All India Scheduled Castes Federation was not the only group that was questioning the functioning of democracy in the Indian system. See the introduction of this volume for a more complete discussion of the democracy debates.

26 B. R. Ambedkar, Speech on the Ratification of the Constitution, "Constituent Assembly of India, Volume 11," November 25, 1949, http://parliamentofindia.nic.in/ 1s/debates/vol.11p11.htm, last accessed March 12, 2015.

27 Shabnum Tejani, "The Necessary Conditions for Democracy: B. R. Ambedkar on Nationalism, Minorities and Pakistan," Economic and Political Weekly 48, no. 50 (December 14, 2013): 117.

28 Stephan Haggard and Robert R. Kaufman, Development, Democracy, and Welfare States: Latin America, East Asia, and Eastern Europe (Princeton, NJ: Princeton University Press, 2008).

29 B. R. Ambedkar, "Caste in India," in Caste and Democratic Politics in India, ed. Ghanshyam Shah (London: Anthem Press, 2002), 68.

30 Srirupa Roy, Beyond Belief: India and the Politics of Postcolonial Nationalism (Durham, NC: Duke University Press, 2007), 24-26.

31 B. R. Ambedkar, "Annihilation of Caste," in The Essential Writings of B. R. Ambedkar, ed. Valerian Rodrigues (New Delhi: Oxford University Press, 2002).

32 B. R. Ambedkar, "Why Indian Labour is Determined to Win This War," Broadcast talk from the Bombay Radio Station, November 9, 1942, R. R. Bhole Files Printed Materials, S. no. 5, NMML, 5.

33 V. T. Rajshekar Shetty, Harijan Atrocities: Why Blame the Police Pamphlet 2 (Bangalore: Dalit Action Committee, 1978), 1.

34 Gurpreet Mahajan, "Contextualizing Minority Rights," in Minority Identities and the Nation-State, ed. D. L. Sheth and Gurpreet Mahajan (New Delhi: Oxford University Press, 1999), 64-67.

35 Rao, The Caste Question, 140; Correspondence between R. R. Bhole and M. K. Gandhi, 1935, R. R. Bhole Papers, Speeches and Writing by Him. S. No. 2, NMML.

36 B. R. Ambedkar, Communal Deadlock and the Way to Solve it (Bombay: Bhim Patrika Publications, 1945).

37 Jinnah-Nehru Correspondence including Gandhi-Jinnah and Nehru Nawab Ismail Correspondence (Lahore: Accurate Printers, nd), 79; Nehru/Ambedkar correspondence, December 1947, Ambedkar Papers, NMML. 
38 Gyanendra Pandey, "Can a Muslim Be an Indian," Comparative Studies in Society and History 41, no. 4 (October 1999).

39 Hamara Harijan Bhai, pamphlet, 1967 in LOC Asia Reading Room, Pamphlet and Ephemera Collection.

40 Gramsci argued that hegemony often function through a reversion to a sense of common sense as the truth defined by a majority-leaving the minority voiceless. Antonio Gramsci, Selections from the Prison Notebooks of Antonio Gramsci, ed. and trans. Quintin Hoare and Geoffrey Nowell Smith (New York: International Publishers, 1999), 327-343; Arun K. Patnaik, "Gramsci's Concept of Common Sense: Towards a Theory of Subaltern Consciousness in Hegemony Processes," Economic and Political Weekly 23, no. 5 (January 30, 1988): PE2-PE10.

41 In this, Sivaraj is specifically referring to the exclusion of Scheduled Castes concerns in the Cripps mission. Report of the Proceedings of the Third Session of the All India Depressed Classes Conference Nagpur, July 18 and 19, 1942, 24.

42 B. R. Ambedkar, Labour and Parliamentary Democracy, Delhi (Indian Federation of Labour), 1943; R. R. Bhole Papers, NMML, Printed Materials, S. no. 6.

43 Upendra Baxi, "Indian Democracy: A Critique," in Challenges to Democracy in India, ed. Rajesh Basrur (New Delhi: Oxford University Press, 2009), 57.

44 Carl Schmitt, The Crisis of Parliamentary Democracy, trans. Ellen Kennedy (Boston: MIT Press, 1988), 9-17.

45 B. R. Ambedkar, "Why Indian Labour is Determined to Win this War," 2.

46 B. R. Ambedkar, Labour and Parliamentary Democracy, 6.

47 Valerian Rodrigues, "Two Discourses on Democracy in India," in Challenges to Democracy in India, ed. Rajesh Basrur (New Delhi: Oxford University Press, 2009), 33.

48 Chandra Bhan Prashad, Dalit Phobia: Why Do They Hate Us (New Delhi: Vitasta Publishing, 2006), 125-113; D. N., "Gandhi, Ambedkar, and Separate Electorates Issue," Economic and Political Weekly 26, no. 21 (May 25, 1991): 1328-1330.

49 Gail Omvedt, Ambedkar: Towards an Enlightened India (New Delhi: Viking Publications for Penguin, 2004), 140.

50 There were Dalit organizations, especially the Congress-affiliated All India Depressed Classes League, who argued that joint electorates were necessary for the full inclusion of Dalits into Indian society. G. M. Thaware, "Salvation of the Depressed Classes Lies in Joint Electorates," Hitavada Press, Nagpur, March 31, 1932, in Ambedkar Papers, NMML.

51 Jaffrelot, 85.

52 Letter between Sivaraj and the Standing Committee All India Scheduled Castes Federation marked confidential, June 18, 1945, Ambedkar Papers, NMML.

53 In late 1951, Ambedkar wrote a letter to Kamalakant Chitre arguing that a low cap should be placed on the allowed expenditures permitted in races for seats reserved for Scheduled Castes people, because in general neither the candidates nor the party had money to spend on their campaigns, and this meant good candidates were declining to run for office. Ambedkar papers, NAI.

54 Speech, 10/27/1951 in Ramdasspur Jullundar, Punjab, Ambedkar Papers, NMML.

55 Dwaipayan Sen, "No Matter how, Jogendranath Had to Be Defeated: The Scheduled Castes Federation and the Making of the Partition in Bengal, 1945-1947," Indian Economic and Social History Review 49, no. 3 (2012): 327-335.

56 Speech 10/27/1951, Ambedkar Papers, NMML.

57 Ibid.

58 V. N. Barve, “A Note on the Harijan Problem in Maharashtra, 1941," page 43 in Ambedkar papers, NMML.

59 Grievances of the Scheduled Castes: Memorandum submitted to His Excellency the Governor-General on 29th October, 1942, Ambedkar Papers, File no. 10, NMML, 8.

60 Ibid., 9. 
61 Sivaraj, Report of the Proceedings of the Third Session of the All India Depressed Classes Conference, Nagpur, July 18 and 19, 1942.

62 Dipesh Chakrabarty, Provincializing Europe: Postcolonial Thought and Historical Difference (Princeton, NJ: Princeton University Press, 2000), 97-113; Gyanendra Pandey, "It's Not About the Number," Outlook India, August 25, 2014, www.outlook india.com/article/its-not-about-the-numbers/291654;

63 A. Satyanarayana, "Articulation of Self and the Other: Emergence of the Dalit Movement in Andhra Pradesh," in Reflections on Dalit and Minorities Issues: An Anthology, ed. Mohd. Mujtaba Khan (New Delhi: Dr. K. R. Narayanan Centre for Dalit and Minorities Studies, Jamia Millia Islamia, and Kanishka Publishers, 2007), 50-51.

64 Ramnarayan S. Rawat, "Partition Politics and Achhut Identity: A Study of the Scheduled Castes Federation and Dalit Politics," in The Partitions of Memory: The Afterlife of the Division of India, ed. Suvir Kaul (Bloomington, IN: Indiana University Press, 2002), 129-130.

65 Grievances of the Scheduled Castes, 10.

66 Bandyopadhyay, 932.

67 Partha Chatterjee, Politics of the Governed: Reflections on Popular Politics in Most of the World (New York: Columbia University Press, 2004), 14-20.

68 Gayatri Spivak, "Responsibility," boundary 2 21, no. 3 (Autumn, 1994): 22.

69 R. R. Bhole, "An Untouchable Speaks," Bhole Papers, Speeches and Writings by him, no. 4, NMML, Private Papers Archives, 11.

70 B. R. Ambedkar, "Political Safeguards for Depressed Classes," in The Essential Writings of B. R. Ambedkar, ed. Valerian Rodrigues (New Delhi: Oxford University Press, 2002), 369-381.

71 B. R. Ambedkar, Labour and Parliamentary Democracy, 7.

72 B. R. Ambedkar, Speech on the Ratification of the Constitution, "Constituent Assembly of India, Volume 11," November 25, 1949.

73 T. H. Marshall and Tom Bottomore, Citizenship and Social Class (London: Pluto Press, 1992).

74 B. R. Ambedkar, Speech on the Ratification of the Constitution, "Constituent Assembly of India, Volume 11," November 25, 1949.

75 Ibid.

76 B. R. Ambedkar, "Communal Deadlock and the Way to Solve it," Address to the Session of the All India Scheduled Castes Federation, Bombay, May 6 1945, 16.

77 Milind Wakankar, Subalternity and Religion: The Prehistory of Dalit Empowerment in South Asia (London: Routledge, 2010), 4.

78 B. R. Ambedkar, What Congress and Gandhi Have Done to the Untouchables, chapter 8, "The Real Issue," www.ambedkar.org/ambcd/41I.What\%20Congress $\% 20$ and\%20Gandhi\%20CHAPTER\%20VIII.htm.

79 B. R. Ambedkar, "Scheduled Castes Will Fight for National Independence," Speech, September 20, 1944, Ambedkar Papers, NMML.

80 Gyanendra Pandey, "Introduction: The Difference of Subalternity," in Subalternity and Difference: Investigations from the North and the South, ed. Gyanendra Pandey (London: Routledge, 2011), 8-10; Rao, The Caste Question, 123-130.

81 B. R. Ambedkar, "Communal Deadlock and the Way to Solve it," 1.

82 Wakankar, 18.

83 B. R. Ambedkar to Kamalakant Chitre, October 21, 1951, Ambedkar Papers, NAI.

84 "Election Manifesto of the All India Scheduled Castes Federation," 1952 in Ambedkar Papers, NMML, 1.

85 Ibid., 2.

86 Ibid., 4.

87 Ibid., 14.

88 "Statement Issued by B.K. Gaikwad, President, Bombay State Scheduled Castes Federation," Ambedkar Papers, NAI. 
72 Democracy, voice, and principle

89 Speech at Ramdasspur 10/27/1951 Ambedkar Papers, NMML.

90 Ibid.

91 Kanshi Ram, The Chamcha Age: An Era of the Stooges (Released on 24 September, 1982 on the 50th Anniversary of the Poona Pact (New Delhi: Kanshi Ram, 1982)), especially sections III and IV; Kancha Ilaia The Weapon of the Other: Dalitbahujan Writings and the Remaking of Indian Nationalist Thought (New Delhi: Pearson, 2010). 


\section{Notes}

1 An example of the ability to organize at both the regional and AIWC levels was found in Kolhapur, where the local AIWC branch asked permission to join a regionally organized umbrella organization, the Central Kolhapur Mahila Mandal. The AIWC agreed provisionally, assuming the Kolhapur branch remained primarily loyal to the central AIWC. "Standing Committee Minutes," F. No. 337, All India Women's Conference (AIWC) papers NMML, 15-16.

2 Rameshwari Nehru, "Tour of the Sind," Roshni 2, no. 4 (December 1940): 46. Rameshwari Nehru was an exemplary worker in the women's movement. She married a nephew of Motilal Nehru, and thus, was Jawaharlal Nehru's cousin. In 1909, she edited Stree Darpan, a women's journal. She was the president of the AIWC several times. After independence she worked with the diplomatic service, leading missions to Tokyo among other places.

3 Nehru "Tour of the Sind," 46.

4 Margaret Cousins, Indian Womanhood Today (Allahabad: Kitabistan, 1947), 30; Kamaladevi Chattopadhyay, Indian Women's Battle for Freedom (New Delhi: Abhinav, 1983), 7-8.

5 "On the Amendment of the Constitution," F. No. 211, AIWC Papers, NMML.

6 If pragmatism were the issue, the AIWC could have easily become a vassal organization for the Indian National Congress, which would immediately swell their membership and raise their profile nationally. Indeed the AIWC had a problem with a branch that tried to do exactly this in the mid-1940s. Instead the focus on principle over pragmatism in political expression mimics the claims by the All India Scheduled Castes Federation, see Chapter 2 of this volume.

7 Rajkumari Amrit Kaur, "On Social Service," in Selected Speeches and Writings of Rajkumari Amrit Kaur, ed. G. Borkar (New Delhi: Archer Publications, 1961), 200.

8 Geraldine Forbes, "From Purdah to Politics: The Social Feminism of the All India Women's Organizations," in Separate Worlds: Studies of Purdah in South Asia, ed. Hanna Papanek and Gail Minault (New Delhi: Chanakya Publications, 1982), 226-227; Shahida Lateef "Defining Women through Legislation," in Zoya Hasan Forging Identities: Gender, Communities, and the State (New Delhi: Kali for Women, 1994), 54-55.

9 "Rules for Affiliation," F. No. 337, and "Standing Committee Minutes," F. No. 217 AIWC papers, NMML.

10 Mrinalini Sinha, Specters of Mother India: The Global Restructuring of an Empire (Durham, NC: Duke University Press, 2006).

11 Dhanvanti Rama Rau, Roshni Special Number (1946); It seems worth noting that the AIWC only worked with women already organized or women who organized themselves into women's branches of the central AIWC. At the same time that this movement was underfoot, women were participating in grassroots movements and local agitations that were not defined as "organized." Denying that these women and their activities were part of the "women's movement" would deny the importance of poor women's work for women's equality, as many of these movements were waged by poor women, Dalits, or adivasis, exactly the women that the organized women's groups were trying to reach out to, both as aid beneficiaries and less elite members. See Sharmila Rege, "Dalit Women Talk Differently: A Critique of Difference and Toward a Dalit Feminist Standpoint Position," Economic and Political Weekly 33, No. 44 (October 31-November 6, 1998): WS39-WS46.

12 "1951 Grant Application," F. No. 263, All India Women's Conference (AIWC) Papers, NMML.

13 Maitrayee Chaudhuri, "Introduction," in Feminism in India, ed. Maitrayee Chaudhuri (New Delhi: Kali for Women, 2004), xxxiv; Partha Chatterjee, "The Nation and its Women: The Paradox of the Women's Questions," in The Nation and Its Fragments: 
Colonial and Postcolonial Histories (Princeton, NJ: Princeton University Press, 1994), 116-121; Indu Agnihotri and Vina Mazumdar, "Changing Terms of Political Discourse: Women's Movement in India, 1970-1990," Economic and Political Weekly 30, no. 29 (July 22, 1995): 1869.

14 Kenneth Bo Nielson, "Women's Activism in the Singur Movement," in Women, Gender, and Everyday Social Transformation in India, ed. Kenneth Bo Nielson and Anne Valthrop (London: Anthem Press, 2014), 204.

15 Some of these writings include "Tides in the Affairs of Branches," Roshni 2, no. 2 (August 1940): 16-21; "And This Also," Roshni 2, no. 8 (December 1941): 3-4; "The Future," Roshni 1, no. 2 (March 1946): 4; “A Year Hence," Roshni 2, no. 5 (June 1947): 3; Hansa Mehta "August 15 Address," Roshni 3, no. 7 (August 1948): 3-8; "Our Movement," Roshni 3, no. 11 (December 1948): 34.

16 Hansa Mehta, "Random Thoughts on the Women's Conference, 1936," reprinted in Indian Women, ed. Sarala Jag Mohan (New Delhi: Butala and Company, 1981), 175-177; Lakshmi Menon, The Position of Women: Oxford Pamphlets on Indian Affairs (London: Oxford University Press, 1944), 31-32; Mary E. John, "Reframing Globalization: Perspectives from the Women's Movement," Economic and Political Weekly 44, no. 10 (March 7-13, 2009): 48.

17 "The Indian Women's Charter of Rights and Duties (as Ratified by the All India Women's Conference, Calcutta, 1946)," in Female Labour in India, ed. Usha Sharma (New Delhi: Mittal Publications, 2006), 119-128.

18 Radha Kumar, The History of Doing: An Illustrated Account of Movements for Women's Rights and Feminism in India, 1800-1990 (New Delhi: Zubaan, 1993), 54.

19 Geraldine Forbes, "Education for Women," in Women and Social Reform in Modern India, ed. Sumit Sarkar and Tanika Sarkar (Bloomington, IN: Indiana University Press, 2008), 58-77.

20 Aparna Basu and Bharti Ray, Women's Struggle: A History of the All India Women's Conference, 1927-1990 (New Delhi: Manohar, 1990), 4-10.

21 Purdah is the practice of keeping women out of sight of men who were not close family members.

22 Margaret Cousins, Indian Womanhood Today (Allahabad: Kitabistan, 1947).

23 Mangala Subramaniam, The Power of Women's Organizing: Gender, Caste, and Class in India (Oxford: Lexington Books, 2006), 30.

24 Mrinalini Sinha, "Gender in the Critiques of Colonialism and Nationalism: Locating the 'Indian Woman," " in Women and Social Reform in Modern India: A Reader, ed. Sumit Sarkar and Tanika Sarkar (Bloomington, IN: Indiana University Press, 2008), 462-467.

25 “All India Women's Conference," The Modern Review 83, no. 1 (January 1948): 17.

26 Wendy Singer, A Constituency Suitable for Ladies: And Other Social Histories of Indian Elections (Oxford: Oxford University Press, 2007).

27 Srimati Vijaya Lakshmi Pandit, "Welcome Address" given at the 14th Session of the All India Women's Conference Allahabad, 1940, pp. 3-4, AIWC archives, NMML.

28 Sharmila Rege, "Dalit Women Talk Differently," WS 39-WS46.

29 Janaki Nair, "The Troubled Relationship of Feminism and History," Economic and Political Weekly 43, no. 43 (October 25-31, 2008): 60; Ritu Menon, "Do Women Have a Country?," in From Gender to Nation, ed. Rada Ivekovic and Julie Mostov (New Delhi: Zubaan, 2004), 55-59; Christine Keating, Decolonizing Democracy: Transforming the Social Contract in India (University Park, PA: Pennsylvania State University Press, 2011), 56; Maitrayee Chaudhuri, xix; This is still a problem in the women's movement today, see discussions about the women's reservation movement and the other backward castes in Rajeswari Sunder Rajan, The Scandal of the State: Women, Law, and Citizenship in Postcolonial India (Durham, NC: Duke University Press, 2003), 16; Smita Patel, "Locating Dalit Women in Women's and Dalit Movements," in Development of 
Scheduled Castes and Scheduled Tribes in India, ed. Jagan Karade (Newcastle: Cambridge Scholars Press, 2008), 141-142.

30 Renuka Ray, "Wanted-Social Workers," Roshni 2, no. 1 (December 1940): 29.

31 Aparna Basu and Bharti Ray, Women's Struggle: A History of the All India Women's Conference, 1927-1990, 15.

32 Basu and Ray, 5-6.

33 They felt this way despite the fact that their organizing body, the Women's India Association, worked as a central organizing committee directing the activities of its branches nationwide. Clearly there was more than concern about ability to function that was dictating their decision.

34 Renuka Ray, "An Analysis of Our Movement," Roshni 2 (December 1941): 17-18.

35 Ila Patel, "The Contemporary Women's Movement and Women's Education in India," International Review of Education 44, no. 2/3 (1998): 159.

36 “Communal Unity," Roshni 2, no. 3 (October 1940): 13.

37 Kumar, The History of Doing, 97

38 This section has been revised from Emily Rook-Koepsel, "Constructing Women's Citizenship: The Local, National, and Global Civics Lessons of Rajkumari Amrit Kaur," Journal of Women's History 27, no. 3 (Fall 2017): 159.

39 Upendra Baxi "Indian Democracy: A Critique," in Challenges to Democracy in India, ed. Rajesh Basrur (New Delhi: Oxford University Press, 2009), 63; Anupama Roy, "Democratic Citizenship: From Proportionality to a Continuum Approach to Political Participation," Occasional Working Paper Series Center for Women's Development Studies, New Delhi, 2006.

40 Mary E. John, "Alternate Modernities?: Reservations and Women's Movement in 20th Century India," Economic and Political Weekly 35, no. 43/44 (October 21-November 3, 2000); Maitrayee Chaudhuri, "The Indian Women's Movement," in Feminism in India, ed. Maitrayee Chaudhuri (London: Zed Books, 2004), 117-133.

41 Mrinalini Sinha, Specters of Mother India, 168-173.

42 Padma Anagol, "Rebellious Wives and Dysfunctional Marriages: Indian Women's Discourses and Participation in the Debates over Restitution of Conjugal Rights and the Child Marriage Controversy in the 1880s and 1890s," in Women and Social Reform in Modern India: A Reader, ed. Sumit Sarkar and Tanika Sarkar (Bloomington, IN: Indiana University Press, 2008), 302-304; Mary E. John, “Alternate Modernities?: Reservations and Women's Movement in 20th Century India," Economic and Political Weekly 35, no. 43/44 (October 21-November 3, 2000): 3823-3825.

43 T. H. Marshall, "Citizenship and Social Class," in Citizenship, Social Class, and Other Essays (Cambridge: Cambridge University Press, 1950); Ruth Lister, "Citizenship: Toward a Feminist Perspective," Feminist Review 57 (Autumn 1997): 29; Kathleen Canning, Gender History in Practice: Historical Perspectives on Bodies, Class, and Citizenship (Ithaca: Cornell University Press, 2006), 193-238.

44 Wendy Brown, "Finding the Man in the State," Feminist Studies 18, no. 1 (Spring 1992): 7-34; Nivedita Menon, Recovering Subversion: Feminist Politics Beyond the Law (Urbana: University of Illinois Press, 2004), 209; Nira Yuval-Davis, "Women, Citizenship, Difference," Feminist Review 57 (Autumn 1997): 15.

45 Drucilla K. Barker and Susan F. Feiner, "Affect, Race, and Class: An Interpretive Reading of Caring Labor," Frontiers 30, no. 1 (2009): 55-56.

46 Nitza Berkovitch, From Motherhood to Citizenship: Women's Rights and International Organizations (Baltimore: Johns Hopkins University Press, 1999), 13-14; Rosie Peppin Vaughan "Girls' and Women's Education within UNESCO and the World Bank, 1945-2000," Compare 40, no. 4 (July 2010): 408; Margaret Thornton, "Rapunzel and the Lure of Equal Citizenship," Law Text Culture 8 (2004): 231-262; Anupama Roy, Mapping Citizenship in India (New Delhi: Oxford University Press, 2010), 10-11. 
47 Wendy Sarvasy, "Social Citizenship for a Feminist Perspective," Hyptia 12, no. 4 (1997): 56. Another perspective on this is Susie Tharu, "Citizenship and Its Discontents," in A Question of Silence: The Sexual Economies of Modern India, ed. Janaki Nair and Mary E. John (London: Zed Books, 2000), 216-242.

48 Thanks to Wendy Singer and Uditi Sen for their clarifying comments on this subject.

49 Rajkumari Amrit Kaur, "The Educated Woman in Indian Life, 1952," Selected Speeches and Writings of Rajkumari Amrit Kaur, 191-193.

50 Saroj Gulati, "Rajkumari Amrit Kaur: Profile of a Feminist," Woman with a Mission: Rajkumari Amrit Kaur Centenary Volume (New Delhi: All India Women's Conference, 1989), 68.

51 Rajkumari Amrit Kaur, "Birth of the Indian Women's Movement, 1932," in Challenge to Women (Allahabad: New Literature, 1946), 13; "Sixteenth Session of All India Women's Conference," Modern Review 71, no. 1 (January 1942): 17-18.

52 "The Indian Women's Charter of Rights and Duties," 119-128.

53 Ornit Shani, How India Became Democratic: Citizenship and the Making of the Universal Franchise (Cambridge: Cambridge University Press, 2017).

54 Margaret Cousins, Indian Womanhood Today, 58-59; Leila J. Rupp, "Constructing Internationalism: The Case of Transnational Women's Organizations, 1888-1945," The American Historical Review 99, no. 5 (1994): 1571-1600; Eleanor Newbigin, "Personal Law and Citizenship in India's Transition to Independence," Modern Asian Studies 45, no. 1 (January 2011): 7-32.

55 Sumit Sarkar, "Indian Democracy: The Historical Inheritance," in The Success of India's Democracy, ed. Atul Kohli (Cambridge: Cambridge University Press, 2001), 29-30; Mrinalini Sinha, "Suffragism and Internationalism: The Enfranchisement of British and Indian Women under an Imperial State," Indian Economic Social History Review 36, no. 4 (December 1999): 467; Nivedita Menon, "Citizenship and the Passive Revolution: Interpreting the First Amendment," Economic and Political Weekly, 39, no. 18 (May 1-7, 2004): 1813-1815.

56 Lakshmi Menon, “Women's Rights,” Indian Listener, September 6, 1953.

57 The historiography certainly emphasizes the distinctions that were made between women's organizations involved in social work and women's organizations involved in political action, with many arguing that the transition to national focus was of political agitation overtaking social work. At least for the AIWC, it seems clear to me that local action (the social work aspect of the divide) was seen as political work, but in a local context. I do agree, however, that there was a feeling that as the conference transitioned to more legal and national campaigns the idea of local work that influenced the national agenda became less clear. For explanations of the distinction between political and social work, see Radha Kumar, The History of Doing: An Illustrated Account of Movements for Women's Rights and Feminism in India, 1800-1990 (New Delhi, Kali for Women, 2002); Janaki Nair, Women and Law in Colonial India (New Delhi: Kali for Women; 1996); P. M. Mathew and M. S. Nair, Women's Organizations and Women's Interests (New Delhi: Ashish Publishing House, 1986).

58 Purnima Banerji, "Reconstructing India," Roshni 2, no. 3 (October 1940): 26.

59 Ibid.

60 Samita Sen, "Motherhood and Mothercraft: Gender and Nationalism in Bengal," Gender and History 5, no. 2 (Summer 1993): 239-240.

61 Banerji, 26-27.

62 Norma Alarcon, Caren Kaplan, and Minoo Moallem, "Introduction: Between Woman and Nation," in Between Woman and Nation: Nationalisms, Transnational Feminisms, and the State, ed. Caren Kaplan, Norma Alarcon, and Minoo Moallem (Durham, NC: Duke University Press, 1999), 6-7.

63 Mala Khullar, "Introduction," in Writing the Women's Movement: A Reader, ed. Mala Khullar (New Delhi: Kali for Women, 2006), 4. 
64 Mrinalini Sinha, "Refashioning Mother India: Feminism and Nationalism in LateColonial India," Feminist Studies 26, no. 3 (2000): 623-644.

65 Mathew and Nair argue that welfarist organizations were conservative in the sense that they replicated rhetoric around women's abilities to act in the public. See Mathew and Nair, Women's Organizations, 3-5.

66 Kumkum Sangari and Sudesh Vaid, "Introduction," in Recasting Women: Essays in Colonial History, ed. Kumkum Sangari and Sudesh Vaid (New Delhi: Kali for Women, 1986), 19. The concepts of conservative and progressive women's politics have often been tied to the reform versus political work debate. Reform or social work, often carried out in local areas has been seen as at least conservative if not regressive in its politics, whatever its actual effect, whereas political agitation especially national, legislative work has often been seen as a more progressive, social justice approach to women's politics.

67 Lata Singh, "Visibilising the 'Other' in History: Courtesans and the Revolt," Economic and Political Weekly 42, no. 19 (May 12-18, 2007): 1677-1678.

68 Nandini Deo and Duncan McDuie-Ra, The Politics of Collective Advocacy in India: Tools and Traps (Sterling: Kumarian Press, 2011), 27; Madhu Kishwar, "The Daughters of Aryavarta," Indian Economic and Social History Review 23 (1986): $151-186$.

69 "Grievance against Andhra Branch," F. No. 354 AIWC papers, NMML; Samita Sen, "Towards a Feminist Politics? The Indian Women's Movement in Historical Perspective," in The Violence of Development: The Politics of Identity, Gender and Social Inequality, ed. Karin Kapadia (New Delhi: Kali for Women, 2002), 478-479.

70 Stephanie Tawa Lama-Rewal, "Fluctuating, Ambivalent Legitimacy of Gender as a Political Category," Economic and Political Weekly 36, no. 17 (April 28-May 4, 2001): 1436

71 “All-India Conference Day,” Roshni 1, no. 10/11 (November/December 1946): 4.

72 On the injustices of excluding women from police and married women from schools, see "In the Light," Roshni 3, no. 6 (July 1948): 3; On local service work, see "From Lucknow," Roshni 3, no. 3 (April 1948): 11; "From the Capital," Roshni 3 no. 3 (April 1948): 12; Amrita Basu, "Feminism and Nationalism in India, 1917-1947," Journal of Women's History 7, no. 4 (Winter 1995): 104.

73 Begum Sultan Mir Amiruddin, "The Women's Movement and its Implications," Roshni 2, no. 6 (July 1941): 38-49; "Standing Committee Minutes," F. No. 211, AIWC papers, NMML.

74 Sarojini Naidu, "Message," Roshni 2, no. 7 (August 15, 1947): 3-4.

75 Ritu Menon and Kamla Bhasin, Borders and Boundaries: Women in India's Partition (New Brunswick, NJ: Rutgers University Press, 1998), 190-201; Debjani Sengupta, "From Dandakaranya to Marichjhapi: Rehabilitation, Representation, and the Partition of Bengal (1947)," Social Semiotics 21, no. 1 (February 2011): 116-117.

76 Veena Das, Life and Words: Violence and the Descent into the Ordinary (Berkeley: University of California Press, 2006), 39-41; Urvashi Butalia, The Other Side of Silence: Voices From the Partition of India (Durham, NC: Duke University Press, 2000), 142-144; Anjali Bhardwaj Datta, "Renegotiating the Self: Recovery and Restoration-The 'Gendered' Histories of Partition," The Indian Historical Review 85, no. 2 (July 2008): 194-195.

77 Butalia, 150-152; Debali Mookerjea-Leonard, "Quarantined: Women and the Partition," Comparative Studies of South Asia, Africa and the Middle East 24, no. 1 (2004): 33-46.

78 Gyanendra Pandey, Remembering Partition: Violence, Nationalism and History in India (Cambridge: Cambridge University Press, 2001), 167-174; MookerjeaLeonard, Rajendra Singh Bedi, "Lajwanti," trans. Alok Bhalla, reprinted in Manoa 19, no. 1 (2007) 21-31; Jill Didur, Unsettling Partition: Literature, Gender, Memory (Toronto: University of Toronto Press, 2006), 36-41. 
79 Ritu Menon and Kamla Bhasin, "Recovery, Rupture, Resistance: Indian State and Abduction of Women During Partition," Economic and Political Weekly 28, no. 17 (April 24, 1993) WS2-WS11.

80 Uditi Sen, Citizen Refugee: Forging the Indian Nation After Partition (Cambridge: Cambridge University Press, 2018), 204.

81 Menon and Bhasin, “Recovery, Rupture, Resistance,” WS7; Butalia, 143.

82 Pandey, Remembering Partition, 173.

83 Nirmala Banerjee, "Whatever Happened to the Dreams of Modernity? The Nehruvian Era and Woman's Position," Economic and Political Weekly 33, no. 17 (1998): 2-7.

84 I was not able to find the original pamphlet, and the AIWC papers did not include it, so I do not know exactly what the pamphlet said, or even what critiques were made in it. But based on the content and tone of the correspondence between the central AIWC and the Baroda Branch, I suspect the pamphlet was advocating for an AIWC that encouraged more mass outreach and a more "democratic" tone.

85 F. No. 43, 23 AIWC papers, NMML.

86 Ibid., 24-25.

87 Ibid., 25.

88 "Grievance against Andhra Branch," F. No. 354 AIWC papers, NMML; "Grievance against Chittagong Branch," F. No. 415, AIWC papers, NMML.

89 NMML, AIWC papers F. No. 44, 122.

90 NMML, AIWC papers F. No. 38, 47.

91 Rochona Majumdar, "Family Values in Transition: Debates around the Hindu Code Bill," in From the Colonial to the Postcolonial: India and Pakistan in Transition, ed. Dipesh Chakrabarty, Rochona Majumdar, and Andrew Sartori (New Delhi: Oxford University Press, 2007), 223-226; Lateef, 50-53.

92 Basu and Ray, Women's Struggle, 50.

93 There have been many books written about the interpretation of the idea of "local laws" as it was translated into the Indian context. See, for example, C. A. Bayly, Empire and Information: Intelligence Gathering and Social Communication in India, 1780-1870 (Cambridge: Cambridge University Press, 2000).

94 Personal law is still functioning in India today. Recently cases, like the Shah Bano case, have tried to dislodge the power of personal law, but the valence of personal law is very complicated. In the Shah Bano case, for example, the idea of personal law as a barrier to uniform legal rights for divorced women was tied into a discussion about whether or not Islam was fundamentally discriminatory against women. The question of minority rights, as a function of personal law is an important problem. For some discussion on debates surrounding the issues inherent in the personal law debate, see Rajeswari Sunder Rajan, "Women between Community and State: Some Implications of the Uniform Civil Code Debates in India," Social Text 65, no. 8 (2000): 55-82; Susie Tharu and Tejaswini Niranjana, "Problems for a Contemporary Theory of Gender," in Gender and Politics in India, ed. Nivedita Menon (New Delhi: Oxford University Press, 2000), 496-497; Flavia Agnes, Law and Gender Equality: The Politics of Women's Rights in India (New Delhi: Oxford University Press, 1999); Zoya Hasan, Forging Indentites: Gender, Communications, and the State (New Delhi: Kali for Women, 1996).

95 Eleanor Newbigin, The Hindu Family and the Emergence of Modern India: Law, Citizenship, and Community (Cambridge: Cambridge University Press, 2013).

96 Rajan, "Women between the Community and the State," 63.

97 "The Forces of Reaction," Roshni 3, no. 8 (September 1948): 2-3.

98 Mithan Lam, An All India Civil Code [Bombay: All India Women's Conference, 1947].

99 Zoya Hasan, "Gender Politics, Legal Reform, and the Muslim Community in India," in Appropriating Gender: Women's Activism and Politicized Religion in South Asia, 
ed. Patricia Jeffery and Amrita Basu (New York: Routledge, 1998), 74-76; Susanne Hoeber Rudolph and Lloyd I. Rudolph, "Living with Difference in India," The Political Quarterly 71 (August 2000): 32-34.

100 Newbigin, 1-27.

101 Janaki Nair, Women and Law in Colonial India (New Delhi: Kali for Women; 1996), 200.

102 Many very important AIWC leaders were vocal about their religious minority status. Rajkumari Amrit Kaur spoke out about the discriminatory practices against Christian women, while Begum Shareefah Hamid Ali spoke publicly about being an Indian Muslim. Still the vast majority of women in the AIWC were upper-caste Hindus. As far as normativity of Hinduism, see Madhu Kishwar, "Codified Hindu Law: Myth and Reality," Economic and Political Weekly 29, no. 33 (August 13, 1994): 2145-2161; Rochona Majumdar, “A History of Women's Rights: A NonHistoricist Reading," Economic and Political Weekly 38, no. 22 (May 31-June 6 2003): 2130-2134.

103 "Well Done Begum Eshan Qadir," Roshni 1, no. 1 (1946): 2.

104 Chitra Sinha, "Images of Motherhood: The Hindu Code Bill Discourse," Economic and Political Weekly 42, no. 43 (October 27-November 2, 2007): 49-57.

105 Hansa Mehta, "Role of Women in the Social Development of India," in Indian Women, ed. Sarala Jag Mohan (Delhi: Butala and Company, 1981), 105.

106 Renuka Ray, "The Background of the Hindu Code Bill," Pacific Affairs 25, no. 3 (September 1952): 268-277.

107 Rameshwari Nehru, “The Half-Yearly Meeting of the All India Women's Conference," Roshni 2, no. 6 (July 1941): 8-19.

108 "The Indian Women's Charter of Rights and Duties (as Ratified by the All India Women's Conference, Calcutta, 1946)," in Female Labour in India, ed. Usha Sharma (New Delhi: Mittal Publications, 2006), 119-128.

109 Ibid. 127.

110 Kumar, The History of Doing, 97; John, "Reframing Globalisation," 48.

111 Kumar, The History of Doing, 97-114.

112 Nandita Gandhi, "Masses of Women, but where is the Movement? A Case Study of the Anti Price Rise Movement in Bombay, 1972-1975," in Subversive Women: Women's Movements in Africa, Asia, Latin America, and the Caribbean, ed. Saskia Wieringa (New Delhi: Kali for Women, 1995), 213-228.

113 Stree Shakti Sanghatana, We Are Making History...: Life Stories of Women in the Telengana People `s Struggle (New Delhi: Kali for Women, 1989); Urvashi Butalia, Making a Difference: Feminist Publishing in the South (Chestnut Hill, MA: Bellagio, Pub. Network, 1995). 
stock taking and blame assigning, and have often led to central government committees of experts, like the National Integration Council, making suggestions on ways of exposing the innate national unity.

What is not often explored in these countrywide soul-searching missions is the possibility that national unity might be better defined as commitment to the nation rather than base similarity to the ideal Indian. Dissenting politics from the 1940 s and '50s through today have tried to engage critically with the Indian nation in ways that make it more accessible to more and different kinds of Indians; however, the results of such attempts are, by design, less totalizing, less ideal, and less finished than the exclusive style of Indian nationalism often favored by the state machinery. The more ad hoc and incomplete a solution seems, the less appetizing it is for the state, and as a result most of the attempted redefinitions of base concepts considered in this text were ultimately discarded by the state, but retained by politically active citizens. Both of the organizations profiled in this book succeeded in changing the focus of the democracy debates; to emphasize active participation, national inclusion, local and regional determination, or recognition of minorities - all of which continue to be concentrated areas of debate in the Indian public to this day.

The continued popularity of the "All India" naming strategy indicates that the pull toward active citizenship and negotiated unity has survived the state's attempt to unilaterally define the Indian nation. In thinking through the question of the meaning of "All India," democracy, and unity, the All India Scheduled Castes Federation and the All India Women's Conference, among many other organizations, made a commitment to India that changed the meaning of politics in the nation. In many ways, the structure of the All India commitment to a messy democracy and contested but committed unity has continued to be the bedrock of Indian political activism. The two organizations featured here emphasize that the politics of minority in India are not a struggle between "All" and "India," but a reimagining of India where all of the "Alls" are necessary.

\section{Notes}

1 "JNUs Journey from Prestigious to Anti-National," The Hindu, December 29, 2016. www.thehindu.com/news/cities/Delhi/JNU\%E2\%80\%99s-journey-from-\%E2\%80\% 98prestigious\%E2\%80\%99-to-\%E2\%80\%98anti-national\%E2\%80\%99/article169562 39.ece.

2 Mayank Jain, "JNU Student Union President Arrested-Even Though Organisation Had Condemned 'Seditious' Slogans.” Scroll.in, February 12, 2016. https://scroll.in/ article/803497/jnu-student-union-president-arrested-even-though-organisation-hadcondemned-seditious-slogans.

3 Vikas Pathak, Shiv Sunny, and Kritika Sharma Sebastian, "Government Acts Tough, JNU Student Leader Charged with Sedition," The Hindu, February 12, 2016, www. thehindu.com/news/cities/Delhi/Govt.-acts-tough-JNU-student-leader-charged-withsedition/article14075511.ece.

4 Kanhaiya Kumar, "If Anti-National Means This, God Save Our Country," trans. J. P. Yadav, Telegraph, February 16, 2016, www.telegraphindia.com/1160216/jsp/ frontpage/story_69576.jsp; Nalin Mehta, 'Redefining 'Azadi' in India: The Prose of Anti-Sedition,” South Asian History and Culture 7, no. 3 (April 2016): 322-323. 


\section{Conclusion}

5 Paroj Banerjee, "The Crackdowns on Universities and the Narrowing of "Nationalism" in India," South Asia@LSE blog, February 29, 2016, http://eprints.lse.ac. uk/74780/1/blogs.1se.ac.uk-The\%20crackdowns\%20on\%20universities\%20and\%20the $\% 20$ narrowing\%20of\%20nationalism\%20in\%20India.pdf; Saanya Gulati, "Why the JNU Ordeal is about More Than Just Tolerance," South Asia@ LSE blog, February 24, 2016, http://eprints.lse.ac.uk/74782/1/blogs.lse.ac.uk-Why\%20the\%20JNU\%20 ordeal \%20is\%20about $\% 20$ more\%20than\%20just\%20intolerance.pdf.

6 K. N. Panikkar, "Nationalism and Its Detractors," Social Scientist 44, no. 9/10 (September-October 2016): 5.

7 Mehta, 2016; Rochana Majumdar, "Policing Higher Education: A Historian's Perspective," South Asian History and Culture 7, no. 3 (2016): 312-314; Jean-Thomas Martelli and Khaliq Parkar, "Diversity, Democracy, and Dissent: A Study of Student Politics in JNU," Economic and Political Weekly 53, no. 11 (March 17, 2018), www. epw.in/engage/article/diversity-democracy-dissent-study-student-politics-JNU.

8 "JNU Upholds Khalid's Explusion, Kanhaiya's Fine for Anti-India Act," The Daily Pioneer, July 6, 2018, www.dailypioneer.com/2018/page1/jnu-upholds-khalidsexpulsion-kanhaiyas-fine-for-anti-india-act.html.

9 Imran Ahmed Siddiqui, "Vicious Assault on Kanhaiya," Telegraph, February 17, 2016, www.telegraphindia.com/1160218/jsp/frontpage/story_69943.jsp.

10 Kanhaiya Kumar, "If Anti-National Means This, God Save Our Country," trans. J. P. Yadav. Telegraph, February 16, 2016.

11 Harshvardhan, "From Anti-National to Urban Naxal: The Trajectory of Dissent in India," Newsclicks, September 18, 2018, www.newsclick.in/anti-national-urbannaxal-trajectory-dissent-india; Apoorvanand, "Instead of Defending India the Raksha Mantri is Instigating Violence within," The Wire, September 23, 2018, https://thewire. in/politics/nirmala-sitharaman-jnu-anti-national-instigating-violence; Panikkar, 5.

12 "What Happened at Hyderabad Central University that led to Rohith Vemula's Suicide?," India Today, January 18, 2016, www.indiatoday.in/fyi/story/whathappened-at-hyderbad-central-university-that-led-to-rohit-vemula-suicide-304365-2016$01-18$.

13 G. Arunima, "Thought, Policies, and Politics: How May We Imagine the Public University in India," Kronos, 43, no. 1 (2017): 174.

14 Sharmila Rege, "Education as a 'Trutiya Ratna': Towards Phule-Ambedkarite Feminist Pedagogical Practice," Economic and Political Weekly 45, no. 44/45 (October 30-November 12, 2010): 93.

15 Kanchan Chandra, "Caste, Representation, and Enduring Inequality," Current History, 115, no. 780 (2016): 151.

16 Panikkar, 4.

17 Susie Tharu, "Citizenship and its Discontents," in A Question of Silence? The Sexual Economies of Modern India, ed. Mary E. John and Janaki Nair (New Delhi: Kali for Women, 1998), 224-225.

18 Sudipta Kaviraj, The Imaginary Institutions of India: Politics and Ideas (New York: Columbia University Press, 2010), 13-15; Sunil Khilnani, The Idea of India (New York: Farrar, Straus and Giroux, 1999), 21, 30.

19 Cf Arunima, 168.

20 Chandra, 151.

21 Gyanendra Pandey, A History of Prejudice: Race, Caste, and Difference (Cambridge: Cambridge University Press, 2013), 213.

22 Prabash K. Dutta, “What Happened at Bhima Koregaon?” India Today, August 29, 2018, www.indiatoday.in/india/story/what-happened-at-bhima-koregaon-13261752018-08-29.

23 Ibid.

24 Akshay Deshmane, "Bhima Koregaon: 'Urban Naxal' Theory a Ploy to Shield Hindutva Accused?," Huffington Post, August 30, 2018, www.huffingtonpost. 
in/2018/08/30/bhima-koregaon-urban-naxal-theory-a-ploy-to-shield-hindutva-accused a $23512437 /$.

25 Shoumojit Banerjee, "Bhima Koregaon Clashes: Pune Police Arrest Five Activists in Mumbai, Delhi, and Nagpur," The Hindu, June 6, 2018, www.thehindu.com/news/ national/other-states/bhima-koregaon-clashes-pune-police-arrest-five-activists-across3-cities/article24094372.ece.

26 The Naxal movement in India was a Maoist political action started in Naxalbari in Northeast India. The movement itself petered out in the late 1960s, but Maoist/Naxal political and paramilitary movements have continued especially in low economic areas like Chhattisgarh and Odisha. In 2010, then Prime Minister Manmohan Singh claimed that Naxalites remain the number-one threat to the Indian nation.

27 Ajaz Ashraf, "Interview: Why are the BJP and RSS (and the Indian State) Obsessed by 'Urban Naxals'?," Scroll.in, October 20, 2018, https://scroll.in/article/897506/ interview-why-are-the-bjp-and-rss-and-the-indian-state-obsessed-by-urban-naxals.

28 "Who Is an Urban Naxal Asks Romila Thapar," The Hindu, September 30, 2018, www.thehindu.com/news/national/who-is-an-urban-naxal-asks-romila-thapar/article25 088465.ece.

29 Shalini Rajvanshi, "What is the Bhim Army?," Indian Express, May 18, 2018, https:// indianexpress.com/article/what-is/what-is-the-bhim-army-5171341/.

30 Vinay Lal, "Manmohan and the Naxalites," Manas, October 2009, http://southasia. ucla.edu/history-politics/current-affairs/manmohan-singh-naxalites/.

31 Vivashwan Singh, " "Ghoul' and the Specter of Totalitarianism," Economic and Political Weekly 53, no. 42 (October 20, 2018), www.epw.in/engage/article/\%E2\% 80\%98ghoul\%E2\%80\%99-and-spectre-totalitarianism?0=ip_login_no_cache\%3D796 9f5f5edac5a359a8e44c7064b3d58.

32 "JNU Students Eat Meat, Smoke, Dance Naked, and Have Sex: BJP MLA Gyan," India Today, February 23, 2016, www.indiatoday.in/india/story/in-jnu-studentsdance-naked-use-3-000-condoms-and-eat-meat-says-bjp-mla-310035-2016-02-23.

33 Partha Chatterjee, "Colonialism, Nationalism, and Colonized Women: The Contest in India," American Ethnologist: Journal of the American Ethnological Society 16, no. 4 (November 1989): 622-633; Uma Narayan, Dislocating Cultures: Identities, Traditions, and Third World Feminisms (New York: Routledge, 1997), 1-44; Geraldine Forbes, "Politics of Respectability: Indian Women and the Indian National Congress," in The Indian National Congress: Centenary Highlights, ed. D. A. Low (New Delhi: Oxford University Press, 1988), 54-97.

34 "Shehla Rashid Speaks up for Interfaith Love, Receives Rape Threats," The Quint, February 14, 2018, www.thequint.com/news/india/shehla-rashid-interfaith-marriagesrape-threats-facebook-deactivated.

35 The experience of being harassed for writing about women's issues, being an outspoken feminist, or even being a professional woman across many geographic contexts, has been eagerly reported. Being shamed or threatened as a way to make women less visible has always been a powerful political tactic. The harassment is also more pronounced when the women who are speaking are minority women (Dalits, women of color, Jewish women, or women in male-dominated fields.) See Michelle Goldberg, "Feminist Writers are so besieged by online abuse that some have begun to retire," Washington Post, February 20, 2015, www.washingtonpost.com/opinions/ online-feminists-increasingly-ask-are-the-psychic-costs-too-much-to-bear/2015/02/19/ $3 \mathrm{dc} 4 \mathrm{ca} 6 \mathrm{c}-\mathrm{b} 7 \mathrm{dd}-11 \mathrm{e} 4-\mathrm{a} 200-\mathrm{c} 008 \mathrm{a} 01 \mathrm{a} 6692$ _story.html? noredirect $=$ on\&utm_term $=$. fb09e4aa22e2; Afua Hirsch, "Rape Threats and Racism Are Vile but Women Won't Be Trolled into Silence," Guardian, June 13, 2018, www.theguardian.com/commentisfree/2018/jun/13/rape-threats-racism-women-trolled-silence-jess-phillips; Catalina Ruiz-Navarro, "Political Violence is Directly Linked to Online Harassment," Women's Media Center April 22, 2016, www.womensmediacenter.com/speechproject/political-violence-directly-linked-online-harassment-catalina-ruiz-navarro; 


\section{Conclusion}

Anne Helen Peterson, "The Cost of Reporting while Female," Columbia Journalism Review (Winter 2016), www.cjr.org/special_report/reporting-female-harassmentjournalism.php/; Kristina M. W. Mitchell, "It's a Dangerous Business, Being a Female Professor," The Chronicle of Higher Education, June 15, 2017, www.chronicle.com/ article/It-s-a-Dangerous-Business/240336; Avital Norman Nathman, "Women Writers Have Always Been Targeted for Anti-Semitic Hatred," Women's Media Center, November 16, 2016, www.womensmediacenter.com/speech-project/women-writershave-always-been-targeted-for-anti-semitic-hatred.

36 Malathi de Alwis, "Motherhood as a Space of Protest: Women's Political Participation in Contemporary Sri Lanka," in Appropriating Gender: Women's Activism and Politicized Religion in South Asia, ed. Patricia Jeffery and Amrita Basu (New York: Routledge, 1998): 188.

37 Tharu, 226.

38 Srila Roy, "Breaking the Cage." Dissent 63, no. 4 (Fall 2016): 75; Kavita Krishnan, "Gendered Discipline in Globalising India," Feminist Review 119 (2018): 76-77.

39 Krishnan, 78.

40 Roy, 74.

41 Nivedita Menon, Recovering Subversion: Feminist Politics Beyond the Law (Urbana: University of Illinois Press, 2004), 166-203.

42 Krishnan, 81.

43 Suvira Jaiswal, "Caste, Gender, and Ideology in the Making of India," Social Scientist 36, no. $1 / 2$ (January-February 2008): 5-6.

44 Jaiswal, 22; Kalpana Wilson, Jennifer Ung Loh, and Navtej Purewale, "Gender, Violence, and the Neoliberal State in India," Feminist Review 119 (2018): 3.

45 Charu Gupta, The Gender of Caste: Representing Dalits in Print (Seattle: University of Washington Press, 2016); Shailaja Paik, Dalit Women's Education in Modern India: Double Discrimination (New York: Routledge, 2014); Sharmila Rege, Writing Caste, Writing Gender: Dalit Women's Testimonios (New Delhi: Zubaan Books, 2006); Anupama Rao, The Caste Question: Dalits and the Politics of Modern India (Berkeley: University of California Press, 2009).

46 Nivedita Menon, "Sexuality, Caste, Governmentality: Contests over 'Gender' in India," Feminist Review 91 (2009): 96.

47 Ibid.

48 Christine Keating, Decolonizing Democracy: Transforming the Social Contract (University Park, PA: Pennsylvania State University Press, 2011).

49 Gyanendra Pandey, "Introduction: The Difference of Subalternity," in Subalternity and Difference: Investigations from the North and the South, ed. Gyanendra Pandey (Oxon: Routledge, 2011), 1-20.

50 Dipesh Chakrabarty, "The In-Human and the Ethical in Communal Violence," in Habitations of Modernity: Essays in the Wake of Subaltern Studies (Chicago: University of Chicago Press, 2002), 140-148.

51 Chantel Mouffe, The Democratic Paradox (London: Verso, 2005), 2-3.

52 Leela Gandhi, Common Cause: Post Colonial Ethics and the Practice of Democracy, 1900-1950 (Chicago: University of Chicago Press, 2014).

53 Jawaharlal Nehru, Discovery of India (New Delhi: Penguin Books India, 2004), 52-54. In the most famous scene of the book, villagers shouting "Bharat Mata ki Jai," which translates to "Victory to Mother India," greet Nehru. In the scene, he baffles the "poorly educated" crowd by asking them to define Mother India. After eliciting stares and insufficient answers, Nehru tells the assembled crowd that Mother India is made up from all the land and all the people of the land that makes up India. The story ends by claiming that as he told the crowds this, "their eyes would light up as if they had made a great discovery" (54). The discovery is, of course, their integral connection to Indian unity. 


\section{Bibliography}

\section{Archival sources}

Aiyer, C. P. Ramaswamy. Personal Papers. National Archives of India, New Delhi.

All India Women's Conference. Papers. Nehru Memorial Museum and Library, New Delhi.

All India P.E.N. Centre. Archival Collection. All India P.E.N. Centre, Mumbai.

Ambedkar, B. R. Papers. National Archives of India, New Delhi.

Ambedkar, B. R. Papers. Nehru Memorial Museum and Library, New Delhi.

Bhole, R. R. Papers. Papers, Speeches and Writings. Private Papers Archives. Nehru

Memorial Museum and Library, New Delhi.

Indian Listener. New York Public Library for the Performing Arts Archive, New York. India Office Records. British Library, London.

Modern Review. Ames Library of South Asia. University of Minnesota, Minneapolis, $\mathrm{MN}$.

Naidu, Sarojini. Personal Papers. National Archives of India, New Delhi.

Newspapers Archives. Nehru Memorial Museum and Library, New Delhi.

Pamphlet and Ephemera Collection. Asia Reading Room. Library of Congress, Washington, DC.

Records Office. Government Papers and Correspondence. National Archives of India, New Delhi.

Roshni. All India Women's Conference Archive. Nehru Memorial Museum and Library, New Delhi.

\section{Published sources}

Agnes, Flavia. Law and Gender Equality: The Politics of Women's Rights in India. New Delhi: Oxford University Press, 1999.

Agnihotri, Indu, and Vina Mazumdar. "Changing Terms of Political Discourse: Women's Movement in India, 1970-1990." Economic and Political Weekly 30, no. 29 (July 22, 1995): 1869-1878.

Ahmed, Nizar. "A Note on Gandhi, Nation and Modernity." Social Scientist 24, no. 5/6 (May-June 2000): 50-69.

Alarcon, Norman, Caren Kaplan, and Minoo Moallem. "Introduction: Between Woman and Nation." In Between Woman and Nation: Nationalisms, Transnational Feminisms, and the State, edited by Caren Kaplan, Norman Alarcon, and Minoo Moallem, 1-16. Durham, NC: Duke University Press, 1999. 


\section{Bibliography}

Ali, Choudhary Rahmat. Complete Works of Rahmat Ali, edited by K. K. Aziz. Islamabad: National Commission on Historical and Cultural Research, 1978.

Ali, Maulana Mohammed. "Speech at the Fourth Plenary Session of the Round Table Conference in London, 19th November, 1930." In Pakistan Movement Historical Documents, edited by G. Allana, 61-85. Karachi: Department of International Relations, University of Karachi, 1969. www.columbia.edu/itc/mealac/ pritchett/00islamlinks/txt_muhammadali_1930.html.

de Alwis, Malathi. "Motherhood as a Space of Protest: Women's Political Participation in Contemporary Sri Lanka." In Appropriating Gender: Women's Activism and Politicized Religion in South Asia, edited by Patricia Jeffery and Amrita Basu, 185-202. New York: Routledge, 1998.

Ambedkar, B. R. What Congress and Gandhi have done to the Untouchables. Gautam Book Center, 1945. www.ambedkar.org/ambcd/41I.What $\% 20$ Congress $\% 20$ and $\% 20$ Gandhi\%20CHAPTER\%20VIII.htm.

Ambedkar, B. R. Pakistan or the Partition of India. Bombay: Thacker, 1946.

Ambedkar, B. R. States and Minorities: What are Their Rights and How to Secure Them in the Constitution of Free India (Memorandum on the Safeguards for the Scheduled Castes Submitted to the Constituent Assembly on Behalf of the All India Scheduled Castes Federation). Bombay: Thacker, 1947.

Ambedkar, B. R. The Essential Writings of B. R. Ambedkar, edited by Valerian Rodrigues. New Delhi: Oxford University Press, 2002.

Ambedkar, B. R. "Caste in India." In Caste and Democratic Politics in India, edited by Ghanshyam Shah, 56-58. London: Anthem Press, 2003.

Amin, Shahid. Event, Memory, Metaphor: Chauri Chaura, 1922-1992. New Delhi: Oxford University Press, 1995.

Amin, Shahid. "Representing the Musalman: Then and Now, Now and Then." In Subaltern Studies XII: Muslims, Dalits and the Fabrications of History, edited by Shail Mayarom, M. S. S. Pandian, and Ajay Skaria, 1-35. Delhi: Permanent Black, 2005.

Anagol, Padma. "Rebellious Wives and Dysfunctional marriages: Indian Women's Discourses and Participation in the Debates over Restitution of Conjugal Rights and the Child Marriage Controversy in the 1880s and 1890s." In Women and Social Reform in Modern India: A Reader, edited by Sumit Sarkar and Tanika Sarkar, 282-312. Bloomington, IN: Indiana University Press, 2008.

Anand, S. "Resurrecting the Radical Ambedkar." Indian Seminar 601 (September 2009). www.india-seminar.com/2009/601/601 s anand.htm.

Apoorvanand. "Instead of Defending India the Raksha Mantri is Instigating Violence within." The Wire, September 23, 2018. https://thewire.in/politics/nirmala-sitharamanjnu-anti-national-instigating-violence.

Appadurai, Arjun. Modernity at Large: Culture Dimensions of Globalization. Minneapolis: University of Minnesota Press, 1996.

Arunima, G. "Thought, Policies, and Politics: How May We Imagine the Public University in India." Kronos 43, no. 1 (2017): 165-184.

Aspects of Indian Music: A Series of Special Articles and Papers Read at the Music Symposia Arranged by All India Radio. New Delhi: Ministry of Information and Broadcasting, 1957.

Ashraf, Ajaz. "Interview: Why are the BJP and RSS (and the Indian State) Obsessed by 'Urban Naxals'?” Scroll.in, October 20, 2018. https://scroll.in/article/897506/interviewwhy-are-the-bjp-and-rss-and-the-indian-state-obsessed-by-urban-naxals. 
Austin, Granville. "The Expected and the Unintended in Working a Democratic Constitution." In India's Living Constitution: Ideas, Practices, Controversies, edited by Zoya Hasan, E. Sridharan, and S. Sudarshan, 319-343. London: Anthem Press, 2005.

Balibar, Etienne, and Immanuel Wallerstein. Race, Nation, Class: Ambiguous Identities. London: Verso, 1991.

Bandyopadhyay, Sehkar. "Transfer of Power and the Crisis of Dalit Politics in India, 1945-47.” Modern Asian Studies 34, no. 4 (2000): 893-942.

Banerjee, Nirmala. "Whatever Happened to the Dreams of Modernity? The Nehruvian Era and Woman's Position." Economic and Political Weekly 33, no. 17 (1998): WS2WS7.

Banerjee, Paroj. "The Crackdowns on Universities and the Narrowing of 'Nationalism' in India.”South Asia@LSE blog, February 29, 2016. http://eprints.lse.ac.uk/74780/1/ blogs.1se.ac.uk-The $\% 20$ crackdowns $\% 20$ on $\% 20$ universities $\% 20$ and $\% 20$ the $\% 20$ narrowing\%20of\%20nationalism\%20in\%20India.pdf.

Banerjee, Prathama. "Thinking Equality: Debates in Bengal, 1870-1940." In Subalternity and Difference: Investigations from the North and the South, edited by Gyanendra Pandey, 131-149. Oxon: Routledge, 2011.

Banerjee, Shoumojit. "Bhima Koregaon Clashes: Pune Police Arrest Five Activists in Mumbai, Delhi, and Nagpur." The Hindu, June 6, 2018. www.thehindu.com/news/ national/other-states/bhima-koregaon-clashes-pune-police-arrest-five-activists-across3-cities/article24094372.ece.

Bannerji, Himani. "Making India Hindu and Male: Cultural Nationalism and the Emergence of the Ethnic Citizen in Contemporary India." Ethnicities 6, no. 3 (2006): 362-390.

Barker, Drucilla K., and Susan F. Feiner. "Affect, Race, and Class: An Interpretive Reading of Caring Labor.” Frontiers: A Journal of Women Studies 30, no. 1 (2009): 41-54.

Barr-Melej, Patrick. Reforming Chile: Cultural Politics, Nationalism, and the Rise of the Middle Class. Chapel Hill, NC: University of North Carolina Press, 2001.

Baruah, Sanjib. "India and Its Northeast: A New Politics of Race." IIC Quarterly 32, no. 2-3 (Winter 2005): 165-176.

Basu, Amrita. "Feminism and Nationalism in India, 1917-1947." Journal of Women's History 7, no. 4 (Winter 1995): 95-107.

Basu, Amrita, and Srirupa Roy. "Beyond Exceptionalism: Violence and Democracy in India." In Violence and Democracy in India, edited by Amrita Basu and Srirupa Roy, 1-35. Calcutta: Seagull Books, 2007.

Basu, Aparna, and Bharti Ray. Women's Struggle: A History of the All India Women's Conference, 1927-1990. New Delhi: Manohar Books, 1990.

Baxi, Upendra. "Emancipation as Justice: Legacy and Vision of Dr. Ambedkar." In From Periphery to Centre Stage: Ambedkar Ambedkarism, and Dalit Future, edited by K. C. Yadav, 49-74. New Delhi: Manohar Books, 2000.

Baxi, Upendra. "Indian Democracy: A Critique." In Challenges to Democracy in India, edited by Rajesh Basrur. New Delhi: Oxford University Press, 2009.

Bayly, C. A. Empire and Information: Intelligence Gathering and Social Communication in India, 1780-1870. Cambridge: Cambridge University Press, 2000.

Berkovitch, Nitza. From Motherhood to Citizenship: Women's Rights and International Organizations. Baltimore: Johns Hopkins University Press, 1999.

Berlant, Lauren. "Cruel Optimism." In The Affect Theory Reader, edited by Melissa Gregg and Gregory J. Seigworth, 93-117. Durham, NC: Duke University Press, 2010. 
Bernadini, Elena. "Everyday Border Surveillance and Trespassing." In Experiences of Freedom in Postcolonial Literatures and Cultures, edited by Annalisa Oboe and Shaul Bassi, 163-175. Oxon: Routledge, 2011.

Beverly, John. "Theses on Subalternity, Representation, and Politics." Postcolonial Studies 1, no. 3 (1999): 305-319.

Bora, Papori. "Between the Human, the Citizen, and the Tribal: Reading Feminist Politics in India's Northeast." International Feminist Journal of Politics 12, no. 3/4 (2010): 241-260.

Brown, Wendy. "Finding the Man in the State." Feminist Studies 18, no. 1 (Sprint 1992): 7-32.

Butalia, Urvashi. Making a Difference: Feminist Publishing in the South. Chestnut Hill, MA: Bellagio Pub. Network, 1995.

Butalia, Urvashi. The Other Side of Silence: Voices from the Partition of India. Durham, NC: Duke University Press, 2000.

Cabrera, Luis. "Gandhiji I Have No Homeland': Cosmopolitan Insights from BR Ambedkar, India's Anti-Caste Campaigner and Constitutional Architect." Political Studies 65, no. 3 (October 2017): 576-593.

Canning, Kathleen. Gender History in Practice: Historical Perspectives on Bodies, Class, and Citizenship. Ithaca: Cornell University Press, 2006.

Chakrabarty, Dipesh. "Postcoloniality and the Artifice of History: Who Speaks for 'Indian' Pasts?" Representations 37 (1992): 1-26.

Chakrabarty, Dipesh. Provincializing Europe: Postcolonial Thought and Historical Difference. Princeton, NJ: Princeton University Press, 2000.

Chakrabarty, Dipesh. "The In-Human and the Ethical in Communal Violence." In Habitations of Modernity: Essays in the Wake of Subaltern Studies, 138-148. Chicago: University of Chicago Press, 2002.

Chakrabarty, Dipesh. "'In the Name of Politics': Democracy and the Power of the Multitude in India." In From the Colonial to the Postcolonial: India and Pakistan in Transition, edited by Dipesh Chakrabarty, Rochona Majumdar, and Andrew Sartori, 31-54. New Delhi: Oxford University Press, 2007.

Chandavarkar, Rajnarayan. "Customs of Governance: Colonialism and Democracy in Twentieth Century India.” Modern Asian Studies 41 (2007): 441-470.

Chandhoke, Neera. "Individual and Group Rights: A View from India." In India's Living Constitution: Ideas, Practices, Controversies, edited by Zoya Hasan, E. Sridharan, and S. Sudarshan, 207-241. London: Anthem Press, 2005.

Chandhoke, Neera. "Participation, Representation, and Democracy in Contemporary India." American Behavioral Scientist 52, no. 6 (February 2009): 807-825.

Chandra, Kanchan. "Caste, Representation, and Enduring Inequality." Current History 115, no. 780 (2016): 150-154.

Chatterjee, Partha. Nationalist Thought and the Colonial World: A Derivative Discourse. Tokyo: The United Nations University, 1986.

Chatterjee, Partha. "Colonialism, Nationalism, and Colonized Women: The Contest in India." American Ethnologist: Journal of the American Ethnological Society 16, no. 4 (November 1989): 622-633.

Chatterjee, Partha. "The Nation and its Women: The Paradox of the Women's Questions." In The Nation and Its Fragments: Colonial and Postcolonial Histories, 116-134. Princeton, NJ: Princeton University Press, 1994.

Chatterjee, Partha. Politics of the Governed: Reflections on Popular Politics in Most of the World. New York: Columbia University Press, 2004. 
Chattopadhey, Kamaladevi. Toward a National Theatre. Aundh: Aundh Publishing Trust, 1945.

Chattopadhey, Kamaladevi. Indian Women's Battle for Freedom. New Delhi: Abhinav, 1983.

Chaturvedi, Sumit. "Caste Publications: The Space for Upper Caste Subculture Politics." Economic and Political Weekly 49, no. 17 (April 26, 2014): 33-37.

Chaudhuri, Maitrayee. "Introduction." In Feminism in India, edited by Maitrayee Chaudhuri, xi-xlvi. London: Zed Books, 2004.

Chaudhuri, Maitrayee. "The Indian Women's Movement." In Feminism in India, edited by Maitrayee Chaudhuri, 117-133. London: Zed Books, 2004.

Chaudhuri, Rosinka. "The Politics of Naming: Derozio in Two Formative Moments of Literary and Political Discourse, Calcutta, 1825-31." Modern Asian Studies 44, no. 4 (2010): 857-885.

Chenoy, Anuradha M. "Women and the Breakdown of the Public Sphere." In Civil Society, Public Sphere, and Citizenship: Dialogues and Perceptions, edited by Rajeev Bhargava and Helmut Reifield, 365-384. New Delhi: Sage Publications, 2005.

Cohn, Bernard S. An Anthropologist among the Historians and Other Essays. New Delhi: Oxford University Press, 1987.

Cohn, Bernard S. Colonialism and Its Forms of Knowledge: The British in India. Princeton, NJ: Princeton University Press, 1996.

Constituent Assembly of India, Volume 1, 2, 5. http://parliamentofindia.nic.in/ls/debates/ debates.htm.

Cousins, Margaret. Indian Womanhood Today. Allahabad: Kitabistan, 1947.

Cousins, Margaret. Indian Women's Battle for Freedom. New Delhi: Abhinav, 1983.

Dahat, Pavan. "JNU Scholars to Revive Dr. Ambedkar's Political School." The Hindu July 2, 2016.

Dalton, Dennis. "Introduction to the Writings about Untouchability." In Mahatma Gandhi: Selected Political Writings, edited by Dennis Dalton, 117. Indianapolis: Hackett Publishing Company, 1996.

Das, Veena. Life and Words: Violence and the Descent into the Ordinary. Berkeley: University of California Press, 2006.

Datta, Anjali Bhardwaj. "Renegotiating the Self: Recovery and Restoration-The 'Gendered' Histories of Partition." The Indian Historical Review 85, no. 2 (July 2008): 191-208.

Debnath, Kunal. “Ambedkar's Ideas of Nation Building in India." Studies in People's History 5, no. 1 (2018): 104-110

Deo, Nandini, and Duncan McDuie-Ra. The Politics of Collective Advocacy in India: Tools and Traps. Sterling: Kumarian Press, 2011.

Deshmane, Akshay. "Bhima Koregaon: 'Urban Naxal' Theory a Ploy to Shield Hindutva Accused?" Huffington Post, August 30, 2018. www.huffingtonpost.in/2018/08/30/ bhima-koregaon-urban-naxal-theory-a-ploy-to-shield-hindutva-accused_a_23512437/.

Devji, Faisal. "Hindu/Muslim/Indian." Public Culture 5, no. 1 (1992): 1-18.

Devji, Faisal. "The Minority as Political Form." In From the Colonial to the Postcolonial: India and Pakistan in Transition, edited by Dipesh Chakrabarty, Rochona Majumdar, and Andrew Sartori, 85-95. New Delhi: Oxford University Press, 2007.

Devji, Faisal. "Nationalism as Antonym of Communalism." The Hindu, December 19, 2014.

Didur, Jill. Unsettling Partition: Literature, Gender, Memory. Toronto: University of Toronto, 2006. 


\section{Bibliography}

Dirks, Nicholas. Castes of Mind: Colonialism and the Making of Modern India. Princeton, NJ: Princeton University Press, 2001.

Diwakar, R. R. "Forward." In An Anthology of Indian Literatures, edited by K. Santhanam. Bombay: Bharatiya Vidya Bhavan, 1969.

Doron, Assa. "Caste Away? Subaltern Engagement with the Modern Indian State." Modern Asian Studies 44, no. 4 (2010): 753-783.

Dutta, Prabash K. "What Happened at Bhima Koregaon?" India Today, August 29, 2018. www.indiatoday.in/india/story/what-happened-at-bhima-koregaon-13261752018-08-29.

Facets of Indian Unity. New Delhi: Ministry of Information and Broadcasting, 1965.

Fernandes, Leela. "Nationalizing 'the Global': Media Images, Cultural Politics, and the Middle Class in India." Media Culture Society 22, no. 5 (September 2000): 611-628.

Forbes, Geraldine. "From Purdah to Politics: The Social Feminism of the All India Women's Organizations." In Separate Worlds: Studies of Purdah in South Asia, edited by Hanna Papanek and Gail Minault, 219-245. Delhi: Chanakya Publications, 1982.

Forbes, Geraldine. "Politics of Respectability: Indian Women and the Indian National Congress." In The Indian National Congress: Centenary Highlights, edited by D. A. Low, 54-97. Delhi: Oxford University Press, 1988.

Forbes, Geraldine. Women in Modern India. Cambridge: Cambridge University Press, 1996.

Forbes, Geraldine. "Education for Women." In Women and Social Reform in Modern India, edited by Sumit Sarkar and Tanika Sarkar, 58-77. Bloomington, IN: Indiana University Press, 2008.

Gandhi, Leela. Affective Communities: Anticolonial Thought, Fin-de-siecle Radicalism, and the Politics of Friendship. Durham, NC: Duke University Press, 2006.

Gandhi, Leela. "The Pauper's Gift: Postcolonial Theory and the New Democratic Dispensation." Public Culture 23, no. 1 (2011): 9-23.

Gandhi, Leela. The Common Cause: Postcolonial Ethics and the Practice of Democracy, 1900-1955. Chicago: University of Chicago Press, 2014.

Gandhi, M. K. Mahatma Gandhi: Selected Political Writings, edited by Denis Dalton. Indianapolis: Hackett Publishing Company, 1996.

Gandhi, M. K. Hind Swaraj and Other Writings, edited by Anthony Parel. Cambridge: Cambridge University Press, 1997.

Gandhi, M. K. Ashram Observances in Action, translated by Valji Govindji Desai. Ahmedabad: Navajivan Publishing House, 1998.

Gandhi, M. K. "The National Flag." In Collected Works of Mahatma Gandhi, vol. 4821 November 1929-2 April 1930, edited by the Ministry of Information and Broadcasting, 351-352. New Delhi: Ministry of Information and Broadcasting, 2000.

Gandhi, M. K. From Yeravda Mandir: Ashram Observances, translated by Valji Govindji Desai, Ahmedabad: Navajivan Publishing House, 2005.

Gandhi, Nandita. "Masses of Women, but Where is the Movement? A Case Study of the Anti Price Rise Movement in Bombay, 1972-1975." In Subversive Women: Women's Movements in Africa, Asia, Latin America, and the Caribbean, edited by Saskia Wieringa, 213-228. New Delhi: Kali for Women, 1995.

Geetha, V. "Bereft of Being: The Humiliations of Untouchability." In Humiliation: Claims and Context, edited by Gopal Guru, 95-107. New Delhi: Oxford University Press, 2009.

Geschiere, Peter. The Perils of Belonging: Autochthony, Citizenship, and Exclusion in Africa \& Europe. Chicago: University of Chicago Press, 2009. 
Ghosh, Durba. "National Narratives and the Politics of Miscegenation: Britain and India." In Archive Stories: Facts, Fictions, and the Writing of History, edited by Antoinette Burton, 27-44. Durham, NC: Duke University Press, 2005.

Goldberg, Michelle. "Feminist Writers Are So Besieged by Online Abuse That Some Have Begun to Retire." Washington Post, February 20, 2015, www.washingtonpost. com/opinions/online-feminists-increasingly-ask-are-the-psychic-costs-too-much-tobear/2015/02/19/3dc4ca6c-b7dd-11e4-a200-c008a01a6692_story.html?noredirect=on\& utm_term=.fb09e4aa22e2.

Gore, M. S. The Social Context of an Ideology: Ambedkar's Social and Political Thought, New Delhi: Sage Publications, 1993.

Gramsci, Antonio. Selections from the Prison Notebooks of Antonio Gramsci, edited by Quiotin Hoare and Geoffrey Nowell Smith. New York: International Publishers, 1999.

Guha, Ramachandra. "Arguments with Sen: Arguments about India." Economic and Political Weekly 40 (October 8-14, 2005): 4420-4425.

Guha, Ramachandra. India After Gandhi: The History of the World's Largest Democracy. New York: HarperCollins, 2007.

Guha, Ramachandra. "The Agrarian Radical: Jotirao Phule." In Makers of Modern India, edited by Ramachandra Guha. Cambridge, MA: Belknap Press, 2011.

Guha, Ranajit. "The Small Voice of History." In Subaltern Studies 9: Writings on South Asian History and Society, edited by Shahid Amin and Dipesh Chakrabarty, 1-12. New Delhi: Oxford University Press, 1996.

Guha, Ranajit. A Rule of Property for Bengal: An Essay on the Idea of Permanent Settlement. Durham, NC: Duke University Press, 1996.

Guha, Ranajit. Dominance without Hegemony: History and Power in Colonial India, Cambridge, MA: Harvard University Press, 1998.

Guha, Ranajit. History of the Limit of World-History. New York: Columbia University Press, 2003.

Gulati, Saanya. "Why the JNU Ordeal Is about More Than Just Intolerance." South Asia@ LSE blog, February 24, 2016. http://eprints.lse.ac.uk/74782/1/blogs.lse.ac.uk-Why\%20 the \%20JNU\%20ordeal\%20is\%20about\%20more\%20than\%20just\%20intolerance.pdf.

Gulati, Saroj. "Rajkumari Amrit Kaur: Profile of a Feminist." In Woman with a Mission: Rajkumari Amrit Kaur Centenary Volume, S. N. Visvanat, 17-32. New Delhi: All India Women's Conference, 1989.

Gupta, Charu. The Gender of Caste: Representing Dalits in Print. Seattle: University of Washington Press, 2016.

Guru, Gopal. "Understanding Ambedkar's Construction of the National Movement." Economic and Political Weekly 33, no. 4 (January 30, 1998): 155-159.

Guru, Gopal. "Misrepresenting the Dalit Movement." In Untouchable: Dalits in Modern India, edited by S. M. Michael, 93-102. Boulder: Lynn Rienner Publishers, 1999.

Guru, Gopal. "Citizenship in Exile: A Dalit Case." In Civil Society, Public Sphere and Citizenship: Dialogues and Perceptions, edited by Rajeev Bhargava and Helmut Reifeld, 260-276. New Delhi: Sage Publications, 2005.

Guru, Gopal. "Experience, Space, and Justice.” In The Cracked Mirror: An Indian Debate on Experience and Theory, edited by Gopal Guru and Sundar Sarukkai, 71-106. New Delhi: Oxford University Press, 2012.

Guru, Gopal. "They Always Speak with their Eyes Cast Down: Dalits on the Margins of Indian Democracy.” Social Text, February 27, 2015. Accessed March 10, 2015. http:// socialtextjournal.org/periscope_article/they-always-speak-with-their-eyes-cast-downdalits-on-the-margin-of-indian-democracy/\#sthash.UfWTS4Q6.58hlz8K7.dpuf. 


\section{Bibliography}

Guru, Gopal, and Anuradha Chakravarty, "Who Are the Country's Poor?: Social Movement Politics and Dalit Poverty." In Social Movements in India: Poverty, Power, and Politics, edited by Raka Ray and Mary Fainsod Katzenstein, 135-160. Lanham, MD: Rowman and Littlefield Publishing, 2005.

Haggard, Stephan, and Robert R. Kaufman. Development, Democracy, and Welfare States: Latin America, East Asia, and Eastern Europe. Princeton, NJ: Princeton University Press, 2008.

Harshvardhan. "From Anti-National to Urban Naxal: The Trajectory of Dissent in India." Newsclicks, September 18, 2018. www.newsclick.in/anti-national-urban-naxaltrajectory-dissent-india.

Hasan, Farhat. "Forms of Civility and Publicness in Pre-British India." In Civil Society, Public Sphere and Citizenship: Dialogues and Perceptions, edited by Rajeev Bhargava and Helmut Reifeld, 84-105. New Delhi: Sage Productions, 2005.

Hasan, Zoya. "Gender Politics, Legal Reform, and the Muslim Community in India." In Appropriating Gender: Women's Activism and Politicized Religion in South Asia, edited by Patricia Jeffery and Amrita Basu, 69-88. New York: Routledge, 1998.

Hasan, Zoya. Forging Identities: Gender, Communications, and the State. New Delhi: Oxford University Press, 1999.

Hasan, Zoya. "Minority Identity, State Policy, and the Political Process." In Writing the Women's Movement, edited by Mala Khullar, 202-217. New Delhi: Zubaan, 2005.

Hasan, Zoya. "Indian Democracy and Inequalities." In Challenges to Democracy in India, edited by Rajesh Basrur. New Delhi: Oxford University Press, 2009.

Hasan, Zoya. Politics of Inclusion: Castes, Minorities, and Affirmative Action. New Delhi: Oxford University Press, 2009.

Hasan, Mushirul, ed. India's Partition: Process, Strategy, and Mobilization. New York: Oxford University Press, 1993.

Hegel, G. W. F. Introduction to the Philosophy of History, translated by Leo Rauch. Indianapolis: Hackett Publishing Company, 1988.

Hirsch, Afua. "Rape Threats and Racism Are Vile but Women Won't Be Trolled into Silence." Guardian June 13, 2018 www.theguardian.com/commentisfree/2018/jun/13/ rape-threats-racism-women-trolled-silence-jess-phillips.

Ibrahim, Saad Eddin. Egypt, Islam, and Democracy. Cairo: American University in Cairo Press, 2002.

Ilaia, Kancha. The Weapon of the Other: Dalitbahujan Writings and the Remaking of Indian Nationalist Thought. New Delhi: Pearson, 2010.

Indian Literatures of Today, edited by Bharatan Kumarappa. Bombay: All India PEN Centre, 1947.

"The Indian Women's Charter of Rights and Duties (As Ratified by the Standing Committee of the All India Women's Conference at its Meeting in Calcutta in July 1946)." In Female Labour in India, edited by Usha Sharma, 119-128. New Delhi: Mittal Publications, 2006.

Indian Writers in Council Proceedings of the First All-India Writers' Conference, Jaipur 1945, edited by K. R. Srinivasa Iyengar. Bombay: International Bookhouse Ltd., 1945.

Iqbal, Muhammad. "Presidential Address, 1930." In Speeches, Writings, and Statements of Iqbal, edited by Latif Ahmed Sherwani, 3-26. Lahore: Iqbal Academy, 1977.

Jaffrelot, Christophe. Dr. Ambedkar and Untouchability: Fighting the Indian Caste System. New York: Columbia University Press, 2005.

Jaffrelot, Christophe. Religion, Caste, and Politics in India. New York: Columbia University Press, 2011. 
Jain, Mayank. "JNU Student Union President Arrested-Even Though Organisation Had Condemned 'Seditious' Slogans." Scroll.in, February 12, 2016. https://scroll.in/ article/803497/jnu-student-union-president-arrested-even-though-organisation-hadcondemned-seditious-slogans.

Jaiswal, Suvira. "Caste, Gender, and Ideology in the Making of India." Social Scientist 36, no. $1 / 2$ (January-February 2008): 1-35.

Jalal, Ayesha. "Exploding Communalism: The Politics of Muslim Identity in India." In Nationalism, Democracy and Development: State and Politics in India, edited by Sugata Bose and Ayesha Jalal, 76-103. New Delhi: Oxford University Press, 1999.

Jalal, Ayesha. The Sole Spokesman: Jinnah, the Muslim League, and the Demand for Pakistan. Cambridge: Cambridge University Press, 1994.

James, Jancy. "Literary Research as National Integration: A Tribute to K. M. George." Indian Literature 48, no. 2 (2004): 139-143.

Jensenius, Francesca R. "Mired in Reservations: The Path-Dependent History of Electoral Quotas in India." Journal of Asian Studies 74, no. 1 (February 2015): 85-105.

Jinnah-Nehru Correspondence Including Gandhi-Jinnah and Nehru Nawab Ismail Correspondence. Lahore: Accurate Printers, 1948.

John, Mary E. “Alternate Modernities?: Reservations and Women's Movement in 20th Century India." Economic and Political Weekly 35, no. 43/44 (October 21-November 3, 2000): 3822-3829.

John, Mary E. "Reframing Globalization: Perspectives from the Women's Movement." Economic and Political Weekly 44, no. 10 (March 7-13, 2009): 46-49.

"JNUs Journey from Prestigious to Anti-National." The Hindu, December 29, 2016. www.thehindu.com/news/cities/Delhi/JNU\%E2\%80\%99s-journey-from-\%E2\%80\% 98prestigious\%E2\%80\%99-to-\%E2\%80\%98anti-national\%E2\%80\%99/article 16956239.ece.

"JNU Students Eat Meat, Smoke, Dance Naked, and Have Sex: BJP MLA Gyan.” India Today, February 23, 2016. www.indiatoday.in/india/story/in-jnu-students-dance-nakeduse-3-000-condoms-and-eat-meat-says-bjp-mla-310035-2016-02-23.

"JNU Upholds Khalid's Explusion, Kanhaiya's Fine for Anti-India Act." The Daily Pioneer. July 6, 2018. www.dailypioneer.com/2018/page1/jnu-upholds-khalidsexpulsion-kanhaiyas-fine-for-anti-india-act.html.

Kabir, Humayun. The Indian Heritage. Bombay: Asia Publishing House, 1955.

Kaul, Suvir. "Introduction." In The Partitions of Memory: The Afterlife of the Division of India, edited by Suvir Kaul, 1-29. Bloomington, IN: Indiana University Press, 2002.

Kaur, Rajkumari Amrit. Challenges to Women. Allahabad: New Literature Press, 1946.

Kaur, Rajkumari Amrit. Selected Speeches and Writings of Rajkumari Amrit Kaur, edited by G. Borkar. New Delhi: Archer Publications, 1961.

Kaur, Rajkumari Amrit. The Concept of Social Service: Its Relation to World Needs and Problems. London: National Council of Social Service, 1961.

Kaviraj, Sudipta. The Imaginary Institutions of India: Politics and Ideas. New York: Columbia University Press, 2010.

Keating, Christine. Decolonizing Democracy: Transforming the Social Contract in India. University Park, PA: Pennsylvania State University Press, 2011.

Khilnani, Sunil. The Idea of India. New York: Farrar, Straus and Giroux, 1999.

Khullar, Mala. "Introduction." In Writing the Women's Movement: A Reader, edited by Mala Khullar, 1-43. New Delhi: Kali for Women, 2006.

Kishwar, Madhu. "The Daughters of Aryavarta." Indian Economic and Social History Review 23 (1986): 151-186. 
Kishwar, Madhu. "Codified Hindu Law: Myth and Reality." Economic and Political Weekly 29, no. 33 (August 13, 1994): 2145-2161.

Kothari, Rajni. Rethinking Democracy. London: Zed Books, 2007.

Krishna, Sankaran. "On Introducing Ambedkar." Economic and Political Weekly 49, no. 16 (April 19, 2014): 24.

Krishnan, Kavita. "Gendered Discipline in Globalising India." Feminist Review 119 (2018): 72-88.

Kumar, Kanhaiya. "If Anti-National Means This, God Save Our Country." Translated by J. P. Yadav. Telegraph, February 16, 2016. www.telegraphindia.com/1160216/jsp/ frontpage/story_69576.jsp.

Kumar, Radha. The History of Doing: An Illustrated Account of Movements for Women's Rights and Feminism in India, 1800-1990. New Delhi: Zubaan, 1993.

Laclau, Ernesto. "Subject of Politics, Politics of the Subject." Difference: A Journal of Feminist Cultural Studies 7, no. 1 (1995): 145-164.

Lal, Vinay. "Manmohan and the Naxalites." Manas (October 2009). http://southasia.ucla. edu/history-politics/current-affairs/manmohan-singh-naxalites/.

Lam, Mithan. An All India Civil Code. Bombay: All India Women's Conference, 1947.

Lama-Rewal, Stephanie Tawa. "Fluctuating, Ambivalent Legitimacy of Gender as a Political Category." Economic and Political Weekly 36, no. 17 (April 28-May 4, 2001): 1435-1440.

Lateef, Shahida. "Defining Women through Legislation." In Forging Identities: Gender, Communities, and the State, edited by Zoya Hasan. New Delhi: Kali for Women, 1994.

Liddle, Joanna, and Rama Joshi. "Gender and Imperialism in British India." Economic and Political Weekly 20, no. 43 (October 26, 1985): W72-W85.

Lister, Ruth. "Citizenship: Toward a Feminist Synthesis." Feminist Review 57 (Autumn 1997): 28-48.

Lorcin, Patricia. "Imperialism, Colonial Identity, and Race in Algeria, 1830-1870: The Role of the French Medical Corp." Isis 90, no. 4 (December 1999): 653-679.

Mahajan, Gurpreet. "Contextualizing Minority Rights." In Minority Identities and the Nation-State, edited by D. L. Sheth and Gurpreet Mahajan, 59-72. New Delhi: Oxford University Press, 1999.

Majumdar, Rochona. “A History of Women's Rights: A Non-Historicist Reading." Economic and Political Weekly 38, no. 22 (May 31-June 6, 2003): 2130-2134.

Majumdar, Rochona. "Family Values in Transition: Debates around the Hindu Code Bill." In From the Colonial to the Postcolonial: India and Pakistan in Transition, edited by Dipesh Chakrabarty, Rochona Majumdar, and Andrew Sartori, 223-240. New Delhi: Oxford University Press, 2007.

Majumdar, Rochona. "Policing Higher Education: A Historian's Perspective." South Asian History and Culture 7, no. 3 (2016): 312-314.

Marshall, T. H., and Tom Bottomore. Citizenship and Social Class. London: Pluto Press, 1992.

Martelli, Jean-Thomas, and Khaliq Parkar. "Diversity, Democracy, and Dissent: A Study of Student Politics in JNU." Economic and Political Weekly 53, no. 11 (March 17, 2018). www.epw.in/engage/article/diversity-democracy-dissent-study-studentpolitics-JNU.

Massey, James. "Minority Rights in the South Asian Countries with Special Reference to India." In Reflections on Dalit and Minorities Issues: An Anthology, edited by Mohd. Mujtaba Khan, 16-39. New Delhi: Dr. K. R. Narayanan Centre for Dalit and Minorities Studies, Jamia Millia Islamia, and Kanishka Publishers, 2007. 
Mathur, J. C. "Music on the A. I. R." In Aspects of Indian Music: A Series of Articles and Papers Read at the Music Symposia arranged by All India Radio. New Delhi: Ministry of Information and Broadcasting, 1957.

Matthew, P. M., and M. S. Nair. Women's Organizations and Women's Interests. New Delhi: Ashish Publishing House, 1986.

Mazzerella, William. "Affect: What Is It Good for?" In Enchantments of Modernity: Empire, Nation, Globalization, edited by Saurabh Dube, 291-309. London: Routledge, 2009.

Mehta, Hansa. "Random Thoughts on the Women's Conference." In Indian Women, edited by Sarala Jag Mohan. Delhi: Butala and Company, 1981.

Mehta, Hansa. "Role of Women in the Social Development of India." In Indian Women, edited by Sarala Jag Mohan. Delhi: Butala and Company, 1981.

Mehta, Nalin. "Redefining 'Azadi' in India: The Prose of Anti-Sedition," South Asian History and Culture 7, no. 3 (April 2016): 322-325.

Mehta, Pratap Bhanu. "The State of Indian Democracy." In Challenges to Democracy in India, edited by Rajesh Basrur, 127-144. New Delhi: Oxford University Press, 2009.

Menon, Dilip. The Blindness of Insight: Essays on Caste in Modern India. Chennai: Navayana, 2006.

Menon, Dilip. "An Inner Violence: Why Communalism in India is about Caste." In The Future of Secularism, edited by T. Tn. Srinivasan, 60-82. New Delhi: Oxford University Press, 2009.

Menon, Lakshmi. The Position of Women: Oxford Pamphlets on Indian Affairs. London: Oxford University Press, 1944.

Menon, Nivedita. Recovering Subversion: Feminist Politics Beyond the Law. Urbana: University of Illinois Press, 2004.

Menon, Nivedita. "Sexuality, Caste, Governmentality: Contests over 'Gender' in India." Feminist Review 91 (2009): 94-112.

Menon, Ritu. "Do Women Have a Country?" In From Gender to Nation, edited by Rada Ivekovic and Julie Mostov, 43-62. New Delhi: Zubaan, 2004.

Menon, Ritu, and Kamla Bhasin. "Recovery, Rupture, Resistance: Indian State and Abduction of Women During Partition." Economic and Political Weekly 28, no. 17 (April 24, 1993): WS2-WS11.

Menon, Ritu, and Kamla Bhasin. Borders and Boundaries: Women in India's Partition. New Brunswick, NJ: Rutgers University Press, 1998.

Metcalf, Barbara. "Observant Muslims, Secular Indians: The Political Vision of Maulan Hussain Ahmad Madani, 1938-57." In From the Colonial to the Postcolonial: India and Pakistan in Transition, edited by Dipesh Chakrabarty, Rochona Majumdar, and Andrew Sartori, 96-118. New Delhi: Oxford University Press, 2007.

Metcalf, Barbara D., and Thomas R. Metcalf. A Concise History of Modern India. Cambridge: Cambridge University Press, 2006.

Mitchell, Kristina M. W. "It's a Dangerous Business, Being a Female Professor." The Chronicle of Higher Education, June 15, 2017 www.chronicle.com/article/It-s-aDangerous-Business/240336.

Mitchell, Lisa. Language, Emotion, and Politics in South India: The Making of a Mother Tongue. Bloomington, IN: Indiana University Press, 2009.

Mookerjea-Leonard, Debali. "Quarantined: Women and the Partition." Comparative Studies of South Asia, Africa and the Middle East 24, no. 1 (2004): 33-46.

Mookerjea-Leonard, Debali, and Rajendra Singh Bedi. "Lajwanti." Translated by Alok Bhalla, reprinted in Manoa 19, no. 1 (2007): 21-31. 


\section{Bibliography}

Moore, R. J. The Crisis of Indian Unity, 1917-1940. Oxford: Clarendon Press, 1974.

Morton, Stephan. "Violence, Law, and Justice in the Colonial Present." In The Oxford Handbook for Post Colonial Studies, edited by Graham Huggan, 179-196. Oxford: Oxford University Press, 2013.

Mouffe, Chantel. The Democratic Paradox. London: Verso, 2005.

Mufti, Aamir. Enlightenment in the Colony: The Jewish Question and the Crisis of Postcolonial Culture, Princeton, NJ: Princeton University Press, 2007.

Mufti, Aamir. "Orientalism and the Institution of World Literatures." Critical Inquiry 36, no. 3 (Spring 2010): 458-493.

Nair, Janaki. Women and Law in Colonial India. New Delhi: Kali for Women, 1996.

Nair, Janaki. "The Troubled Relationship of Feminism and History." Economic and Political Weekly 43, no. 43 (October 25-31, 2008): 57-65.

Narayan, Uma. Dislocating Cultures: Identities, Traditions, and Third World Feminisms. New York: Routledge, 1997.

Nathman, Avital Norman. "Women Writers Have Always Been Targeted for Anti-Semitic Hatred." Women's Media Center November 16, 2016 www.womensmediacenter.com/ speech-project/women-writers-have-always-been-targeted-for-anti-semitic-hatred.

Nehru, Jawaharlal. "The Unity of India." Foreign Affairs 16, no. 2 (January 1938): 231-243.

Nehru, Jawaharlal. An Autobiography, New Delhi: Jawaharlal Nehru Memorial Fund, 2002.

Nehru, Jawaharlal. The Discovery of India. New Delhi: Penguin, 2004.

Nehru, Jawaharlal. "Tryst with Destiny." On Voices of Freedom: The Spirit of Freedom and Progress Speaks through Our Leaders, disc 1 track 2, Saregama Recordings, 2009.

Newbigin, Eleanor. "Personal Law and Citizenship in India's Transition to Independence." Modern Asian Studies 45, no. 1 (January 2011): 7-32.

Newbigin, Eleanor. The Hindu Family and the Emergence of Modern India: Law, Citizenship, and Community. Cambridge: Cambridge University Press, 2013.

Nielson, Kenneth Bo. "Women's Activism in the Singur Movement." In Women, Gender, and Everyday Social Transformation in India, edited by Kenneth Bo Nielson and Anne Valthrop, 203-218. London: Anthem Press, 2014.

O'Hanlon, Rosalind. Caste, Conflict and Ideology: Mahatma Jotirao Phule and Low Caste Protest in Nineteenth Century Western India. Cambridge, MA: Cambridge University Press, 2002.

O'Reilly, Kathleen. “Toilet Insecurity: Urban Women's Everyday Experience of Inadequate Sanitation in India." Paper presented at the Security Challenges in a Turbulent World: International Security Studies Symposium. Norman, Oklahoma, February 25-26, 2015.

Omvedt, Gail. Ambedkar: Towards an Enlightened India. New Delhi: Viking for Penguin Books, 2004.

Omvedt, Gail. Dalit Visions: The Anti-Caste Movement and the Construction of an Indian Identity. New Delhi: Orient Longman, 2006.

Omvedt, Gail. Dalits and the Democratic Revolution: Dr. Ambedkar and the Dalit Movement in Colonial India. New Delhi: Sage Publications, 2014.

Omvedt, Gail. "Ambedkar vs. Gandhi: A Part that Parted." Outlook Magazine (August 20, 2012), www.outlookindia.com/article/a-part-that-parted/281929.

Paik, Shailaja. Dalit Women's Education in Modern India: Double Discrimination. New York: Routledge, 2014.

Palshikar, Sanjay. "Understanding Humiliation." In Humiliation: Claims and Context, edited by Gopal Guru. New Delhi: Oxford University Press, 2009. 
Pandey, Gyanendra. "Can a Muslim be an Indian?" Comparative Studies in Society and History 41, no. 4 (October 1999): 608-629.

Pandey, Gyanendra. "Citizenship and Difference: The Muslim Question in India." In The Unfinished Agenda: Nation-Building in South Asia, edited by Mushirul Hasan and Nariaki Nakazato, 101-127. New Delhi: Manobar Books, 2001.

Pandey, Gyanendra. Remembering Partition: Violence, Nationalism and History in India. Cambridge: Cambridge University Press, 2001.

Pandey, Gyanendra. Routine Violence: Nations, Fragments, and History. Stanford: Stanford University Press, 2006.

Pandey, Gyanendra. "Introduction: The Difference of Subalternity." In Subalternity and Difference: Investigations from the North and the South, edited by Gyanendra Pandey, 1-20. Oxon: Routledge, 2011.

Pandey, Gyanendra. A History of Prejudice: Race, Caste, and Difference. Cambridge: Cambridge University Press, 2013.

Pandey, Gyanendra. "It's Not About the Number." Outlook India (August 25, 2014): www.outlookindia.com/article/its-not-about-the-numbers/291654.

Panikkar, K. N. "Nationalism and Its Detractors." Social Scientist 44, no. 9/10 (September-October 2016): 3-18.

Parchami, Ali. Hegemonic Peace and Empire: The Pax Romana, Britannica, and Americana. Oxon: Routledge, 2009.

Patankar, Bharat and Gail Omvedt. The Dalit Liberation Movement in the Colonial Period. New Delhi: Critical Quest, 2004.

Patel, Ila. "The Contemporary Women's Movement and Women's Education in India." International Review of Education 44, no. 2/3 (1998): 155-175.

Patel, Smita. "Locating Dalit Women in Women's and Dalit Movements." In Development of Scheduled Castes and Scheduled Tribes in India, edited by Jagan Karade. Newcastle: Cambridge Scholars Press, 2008.

Pathak, Vikas, Shiv Sunny, and Kritika Sharma Sebastian. "Government Acts Tough, JNU Student Leader Charged with Sedition.” The Hindu. February 12, 2016. www.thehindu.com/news/cities/Delhi/Govt.-acts-tough-JNU-student-leader-charged-withsedition/article14075511.ece.

Patnaik, Arun K. “Gramsci's Concept of Common Sense: Towards a Theory of Subaltern Consciousness in Hegemony Processes." Economic and Political Weekly 23, no. 5 (January 30, 1988): PE2-PE5, PE7-PE10.

Peterson, Anne Helen. "The Cost of Reporting while Female." Columbia Journalism Review (Winter 2016). www.cjr.org/special_report/reporting-female-harassment-journalism.php/.

Phillips, P. Oomman. "Nehru Survives Challenge, Demands National Unity." Christian Century (November 1, 1950).

Prakash, Gyan. "Secular Nationalism, Hindutva, and the Minority." In The Crisis of Secularisms in India, edited by Anuradha Dingwaney Needham and Rajeswari Sunder Rajan. 133-152. Durham, NC: Duke University Press, 2007.

Prasad, Madhava. "On the Question of a Theory of (Third) World Literature." In Dangerous Liaisons: Gender, Nation, and Postcolonial Perspectives, edited by Anne McClintock, Aamir Mufti, and Ella Shobat, 141-162. Minneapolis: University of Minnesota Press, 1997.

Prashad, Chandra Bhan. Dalit Phobia: Why Do They Hate Us. New Delhi: Vitasta Publishing, 2006.

Radhakrishnan, S. The Spirit of Asia. Washington, DC: Government of India Information Services, 1947.) 
Rajagopalachari, C. Ambedkar Refuted, Bombay: Hind Kitab, 1946.

Rajan, Nalini. Democracy and the Limits of Minority Rights. New Delhi: Sage Publications, 2002.

Rajan, Rajeshwari Sundar. "Women between Community and State: Some Implications of the Uniform Civil Code Debates in India." Social Text 65, no. 8 (2000): 55-82.

Rajan, Rajeshwari Sundar. The Scandal of the State: Women, Law, and Citizenship in Postcolonial India. Durham, NC: Duke University Press, 2003.

Rajvanshi, Shalini. "What is the Bhim Army?" Indian Express, May 18, 2018. https:// indianexpress.com/article/what-is/what-is-the-bhim-army-5171341/.

Ram, Kanshi. The Chamcha Age: An Era of the Stooges. New Delhi: Kanshi Ram, 1982.

Rani, Jeya. "So the Term 'Dalit' Can't Be Used but 'Brahmin' and 6000 Other Caste Names Can." The Wire, September 14, 2018. https://thewire.in/caste/dalit-brahmincaste-names.

Rao, Anupama. "Ambedkar and the Politics of Minority: A Reading." In From the Colonial to the Postcolonial, edited by Dipesh Chakrabarty, Rochona Majumdar, and Andrew Sartori, 137-158. New Delhi: Oxford University Press, 2007.

Rao, Anupama. The Caste Question: Dalits and the Politics of Modern India. Berkeley: University of California Press, 2009.

Rao, Mohan. "Agrarian Power and Unfree Labour." Journal of Peasant Studies 26, no. 2-3 (1999): 242-262.

Rawat, Ramnarayan S. "Partition Politics and Achhut Identity: A Study of the Scheduled Castes Federation and Dalit Politics." In The Partitions of Memory: The Afterlife of the Division of India, edited by Suvir Kaul, 113-139. Bloomington, IN: Indiana University Press, 2002.

Ray, Raka. Fields of Protest: Women's Movements in India. Minneapolis: University of Minnesota Press, 1999.

Ray, Renuka. "The Background of the Hindu Code Bill." Pacific Affairs 25, no. 3 (September 1952): 268-277.

Ray, Renuka. "The All India Conference as a National Forum.” All India Women's Conference Souvenir: 1927-1970. New Delhi: All India Women's Conference, 1971.

Rege, Sharmila. "Dalit Women Talk Differently: A Critique of Difference and Toward a Dalit Feminist Standpoint Position." Economic and Political Weekly 33, no. 44 (October 31-November 6, 1998): WSS9-WS46.

Rege, Sharmila. Writing Caste, Writing Gender: Dalit Women's Testimonios. New Delhi: Zubaan Books, 2006.

Rege, Sharmila. "Education as a "Trutiya Ratna": Towards Phule-Ambedkarite Feminist Pedagogical Practice." Economic and Political Weekly 45, no. 44/45 (October 30-November 12, 2010): 88-98.

Renan, Ernest. "What is a Nation." Translated by Martin Thom, in Nation and Narration, edited by Homi Bhabha. Oxon: Routledge, 1990: 8-22.

Report of the Proceedings of the Third Session of the All India Depressed Classes Conference, Nagpur, July 18 and 19 1942, edited by G. T. Meshram. Nagpur: All India Depressed Classes Association, 1942.

Roberts, Richard. "History and Memory: The Power of Statist Narratives." International Journal of African Historical Studies 33, no. 3 (2000): 513-522.

Rodrigues, Valerian. "Introduction.” In The Essential Writings of B. R. Ambedkar, edited by Valerian Rodrigues, 1-43. New Delhi: Oxford University Press, 2002.

Rodrigues, Valerian. "Two Discourses on Democracy in India." In Challenges to Democracy in India, edited by Rajesh Basrur. Oxford: Oxford University Press, 2009. 
Rook-Koepsel, Emily. "Constructing Women's Citizenship: The Local, National, and Global Civics Lessons of Rajkumari Amrit Kaur." Journal of Women's History 27, no. 3 (Fall 2015): 154-175.

Rook-Koepsel, Emily. "Ghosts of Indian Unity: Difference, Diversity, and Violence." Kairos: A Journal of Critical Symposium. 2, no. 1 (2017): 67-82.

Roy, Anupama. "Democratic Citizenship: From Proportionality to a Continuum Approach to Political Participation." Occasional Working Paper Series for Women's Development Studies, New Delhi, 2006.

Roy, Anupama. Mapping Citizenship in India. New Delhi: Oxford University Press, 2010.

Roy, Arundhati. Field Notes on Democracy: Listening to Grasshoppers. Chicago: Haymarket Books, 2009.

Roy, Srila. "Breaking the Cage." Dissent 63, no. 4 (Fall 2016): 74-83.

Roy, Srirupa. "Instituting Diversity: Official Nationalism in Post-independence India." South Asia 22, no. 1 (1999): 79-99.

Roy, Srirupa. "A Symbol of Freedom: The Indian Flag and the Transformations of Nationalism, 1906-2002." Journal of Asian Studies 65, no. 3 (August 2006): 495-527.

Roy, Srirupa. Beyond Belief: India and the Politics of Postcolonial Nationalism. Durham, NC: Duke University Press, 2007.

Rudolph, Susanne Hoeber, and Lloyd I. Rudoph. "Living with Difference in India." The Political Quarterly 71 (August 2000): 20-38.

Ruiz-Navarro, Catalina. "Political Violence is Directly Linked to Online Harassment." Women's Media Center April 22, 2016. www.womensmediacenter.com/speech-project/ political-violence-directly-linked-online-harassment-catalina-ruiz-navarro.

Rupp, Leila J. “Constructing Internationalism: The Case of Transnational Women's Organizations, 188801945." The American historical Review 99, no. 5 (1994): 1571-1600.

Saberwal, Satish. "Introduction: Civilization, Constitution, Democracy." India's Living Constitution: Ideas, Practices, Controversies, edited by Zoya Hasan, E. Sridharan, and S. Sudarshan, 1-30. London: Anthem Press, 2005.

Sangari, Kumkum, and Sudesh Vaid. "Introduction." In Recasting Women: Essays in Colonial History, edited by Kumkum Sangari and Sudesh Vaid, 1-27. New Delhi: Kali for Women, 1986.

Sanghatana, Stree Shakti. We Are Making History .... Life Stories of Women in the Telengana People's Struggle. New Delhi: Kali for Women, 1989.

Sarkar, Mahua. "Difference in Memory." Comparative Studies in Society and History 48, no. 1 (2006): 139-168.

Sarkar, Sumit. "Indian Democracy: The Historical Inheritance." In the Success of India's Democracy, edited by Atul Kohli, 23-46. Cambridge: Cambridge University Press, 2001.

Sarkar, Sumit. "Indian Nationalism and the Politics of Hindutva." In Making India Hindu: Religion, Community, and the Politics of Democracy in India, edited by David Ludden, 270-293. New Delhi: Oxford University Press, 2005.

Sarukkai, Sundar. "Phenomenology of Untouchability." In The Cracked Mirror: An Indian Debate on Experience and Theory, edited by Gopal Guru and Sundar Sarukkai, 39-48. New Delhi: Oxford University Press, 2012.

Sarvasy, Wendy. "Social Citizenship from a Feminist Perspective." Hyptia 12, no. 4 (1997): 54-73.

Satyanarayana, A. "Articulation of Self and the Other: Emergence of the Dalit Movement in Andhra Pradesh." In Reflections on Dalit and Minorities Issues: An Anthology, edited by Mohd. Muitaba Khan, 40-55. New Delhi: Kanishka Publishers, 2007. 


\section{Bibliography}

Schmitt, Carl. The Crisis of Parliamentary Democracy, translated by Ellen Kennedy. Boston: MIT Press, 1988.

Scott, James. Seeing like a State: How Certain Schemes to Improve the Human Condition have Failed. New Haven: Yale University Press, 1999.

Scott, Joan. Gender and the Politics of History. New York: Columbia University Press, 1999.

Sen, Amartya. "The Politics of History." In Pluralism and Democracy in India: Debating the Hindu Right, edited by Wendy Doniger and Martha C. Nussbaum, 21-35. New York: Oxford University Press, 2015.

Sen, Dwaipayan. "No Matter How, Jogendranath Had to Be Defeated: The Scheduled Castes Federation and the Making of the Partition in Bengal, 1945-1947." Indian Economic and Social History Review 49, no. 3 (2012): 327-335.

Sen, Dwaipayan. The Decline of the Caste Question: Jogendranath Mandal and the Defeat of Dalit Politics in Bengal. Cambridge: Cambridge University Press, 2018.

Sen, Ilina. "Women's Politics in India." In Feminism in India, edited by Maitrayee Chaudhuri, 444-462. New York: Kali for Women, 2004.

Sen, Samita. "Motherhood and Mothercraft: Gender and Nationalism in Bengal." Gender and History 5, no. 2 (Summer 1993): 231-243.

Sen, Samita. "Towards a Feminist Politics? The Indian Women's Movement in Historical Perspective." In The Violence of Development: The Politics of Identity, Gender and Social Inequality, edited by Karin Kapadia, 459-524. New Delhi: Kali for Women, 2002.

Sen, Uditi. Citizen Refugee: Forging the Indian Nation After Partition. Cambridge: Cambridge University Press, 2018.

Sengupta, Debjani. "From Dandakaranya to Marichjhapi: Rehabilitation, Representation, and the Partition of Bengal (1947)." Social Semiotics 21, no. 1 (February 2011): $101-123$.

Shani, Ornit. "Conceptions of Citizenship in India and the "Muslim Question." Modern Asian Studies 44, no. 1 (2010): 145-173.

Shani, Ornit. How India Became Democratic: Citizenship and the Making of the Universal Franchise. Cambridge: Cambridge University Press, 2017.

"Shehla Rashid Speaks up for Interfaith Love, Receives Rape Threats." The Quint February 14, 2018. www.thequint.com/news/india/shehla-rashid-interfaith-marriages-rapethreats-facebook-deactivated.

Sheth, D. L. "The Nation-State and Minority Rights." In Minority Identities and the Nation State, edited by D. L. Sheth and Gurpreet Mahajan, 18-37. New Delhi: Sage Publications, 2002.

Shetty, V. T. Rajshekar. Harijan Atrocities: Why Blame the Police Pamphlet 2. Bangalore: Dalit Action Committee, 1978.

Siddiqui, Imran Ahmed. "Vicious Assault on Kanhaiya." Telegraph, February 17, 2016, www.telegraphindia.com/1160218/jsp/frontpage/story_69943.jsp.

Singer, Wendy. A Constituency Suitable for Ladies: And Other Social Histories of Indian Elections. Oxford: Oxford University Press, 2007.

Singh, Jyotsna G. Colonial Narratives/Cultural Dialogues: "Discoveries" of India in the Language of Colonialism. London: Routledge, 1996.

Singh, Lata. "Visibilising the 'Other' in History: Courtesans and the Revolt." Economic and Political Weekly 42, no. 19 (May 12-18, 2007): 1677-1680.

Singh, Nikhil Pal. Black is a Country: Race and the Unfinished Struggle for Democracy. Cambridge, MA: Harvard University Press, 2004. 
Singh, Ujjwal Kumar. The State, Democracy and Anti-terror Laws in India. New Delhi: Sage Publications India, 2007.

Singh, Vivashwan. "'Ghoul' and the Specter of Totalitarianism." Economic and Political Weekly 53, no. 42 (October 20, 2018). www.epw.in/engage/article/\%E2\%80\%98 ghoul $\% \mathrm{E} 2 \% 80 \% 99$-and-spectre-totalitarianism?0=ip_login_no_cache $\% 3 \mathrm{D} 7969 \mathrm{f5f5ed}$ ac5a359a8e44c7064b3d58.

Sinha, Chitra. "Images of Motherhood: The Hindu Code Bill Discourse." Economic and Political Weekly 42, no. 43 (October 27-November 2, 2007): 49-57.

Sinha, Mrinalini. "Suffragism and Internationalism: The Enfranchisement of British and Indian Women under an Imperial State." Indian Economic Social History Review 36, no. 4 (December 1999): 461-484.

Sinha, Mrinalini. "Refashioning Mother India: Feminism and Nationalism in LateColonial India." Feminist Studies 26, no. 3 (2000): 623-644.

Sinha, Mrinalini. Specters of Mother India: The Global Restructuring of an Empire. Durham, NC: Duke University Press, 2006.

Sinha, Mrinalini. "Gender in the Critiques of Colonialism and Nationalism: Locating the 'Indian Women." " In Women and Social Reform in Modern India: A Reader, edited by Sumit Sarkar and Tanika Sarkar, 477-504. Bloomington, IN: Indiana University Press, 2008.

Skaria, Ajay. "'Can the Dalit Articulate a Universal Position?': The Intellectual, the Social, and the Writing of History." Social History 39, no. 3 (2014): 340-358.

Skaria, Ajay. "Ambedkar, Marx, and the Buddhist Questions." South Asia: Journal of South Asia 38, no. 3 (September 2015): 450-465.

Smith, Lahra. Making Citizens in Africa: Ethnicity, Gender, and National Identity in Ethiopia. Cambridge: Cambridge University Press, 2013.

Spivak, Gayatri. "Responsibility." Boundary 2 21, no. 3 (Autumn, 1994): 19-64.

Sreenivas, Mytheli. Wives, Widows, and Concubines: The Conjugal Family Ideal in Colonial India. Bloomington, IN: Indiana University Press, 2008.

Subramaniam, Mangala. The Power of Women's Organizing: Gender, Caste, and Class in India. Oxford: Lexington Books, 2006.

Tejani, Shabnum. "The Necessary Conditions for Democracy: B. R. Ambedkar on Nationalisms, Minorities, and Pakistan." Economic and Political Weekly 48, no. 50 (December 14, 2013): 701-721.

Thapur, Romila. "Communalism and the Historical Legacy: Some Facets." Social Scientist 18, no. 6/7 (June-July 1990): 4-20.

Tharu, Susie. "Citizenship and Its Discontents." In A Question of Silence: The Sexual Economies of Modern India, edited by Janaki Nair and Mary E. John. London: Zed Books, 2000.

Tharu, Susie, and Tejaswini Niranjana. "Problems for a Contemporary Theory of Gender." In Gender and Politics in India, edited by Nivedita Menon, 93-117. New Delhi: Oxford University Press, 2000.

Thornton, Margaret. "Rapunzel and the Lure of Equal Citizenship." Law Text Culture 8 (2004): 231-262.

Trivedi, Harish. Colonial Transactions: English Literature and India. Manchester: Manchester University Press, 1995.

Varshney, Ashutosh. "Contested Meanings: India's National Identity, Hindu Nationalism, and the Politics of Anxiety." Daedalus 122, no. 3 (Summer 1993): 227-261.

Vaughan, Rosie Peppin. "Girls' and Women's Education within UNESCO and the World Bank, 1945-2000.” Compare 40, no. 4 (July 2010): 405-423. 


\section{Bibliography}

Visweswaran, Kamala. "Small Speeches, Subaltern Gender: Nationalist Ideology and its Historiography." In Subaltern Studies 9: Writings on South Asian History and Society, edited by Shahid Amin and Dipesh Chakrabarty, 83-125. Delhi: Oxford University Press, 1996.

Wakankar, Milind. Subalternity and Religion: The Prehistory of Dalit Empowerment in South Asia. London: Routledge, 2010.

Wallerstein, Immanuel. "The Construction of Peoplehood: Racism, Nationalism, Ethnicity." In Race, Nation, Class: Ambiguous Identities, edited by Immanuel Wallerstein and Etienne Balibar, 71-85. London: Verso, 1991.

Washbrook, David. "The Rhetoric of Democracy and Development in Late Colonial India." In Nationalism, Democracy, and Development: State and Politics in India, edited by Sugata Bose and Ayesha Jalal, 36-49. New Delhi: Oxford University Press India, 2011.

"What Happened at Hyderabad Central University That Led to Rohith Vemula's Suicide?" India Today, January 18, 2016. www.indiatoday.in/fyi/story/what-happenedat-hyderbad-central-university-that-led-to-rohit-vemula-suicide-304365-2016-01-18.

"Who Is an Urban Naxal asks Romila Thapar." The Hindu, September 30, 2018. www. thehindu.com/news/national/who-is-an-urban-naxal-asks-romila-thapar/article25088465. ece.

Wilson, Kalpana, Jennifer Ung Loh, and Navtej Purewale. "Gender, Violence, and the Neoliberal State in India." Feminist Review 119 (2018): 1-6.

Wolpert, Stanley. Tilak and Gokhale: Revolution and Reform in the Making of Modern India. New Delhi: Oxford University Press, 1991.

Yuval-Davis, Nira. "Women, Citizenship, Difference." Feminist Review 57 (Autumn 1997): 4-27.

Zelliot, Eleanor. Dr. Babasaheb Ambedkar and the Untouchable Movement. New Delhi: Blumoon Books, 2004. 